\title{
ASSESSMENT OF ONTARIO'S FEED-IN TARIFF FOR RENEWABLE ENERGY POLICY: THE CASE OF SOLAR PV TECHNOLOGY
}

\author{
By \\ Giovanna Salome Gonzales Calienes \\ MBA, ESAN University, Peru, 2002
}

B.Sc. in Industrial Engineering, Universidad Nacional de Ingenieria, Peru, 1995

\author{
A thesis \\ presented to Ryerson University \\ in partial fulfillment of the \\ requirements for the degree of \\ Master of Applied Science \\ in the Program of
}

Environmental Applied Science and Management

Toronto, Ontario, Canada, 2014

CGiovanna S. Gonzales Calienes 2014 


\section{AUTHOR'S DECLARATION \\ AUTHOR'S DECLARATION FOR ELECTRONIC SUBMISSION OF A THESIS}

I hereby declare that I am the sole author of this thesis. This is a true copy of the thesis, including any required final revisions, as accepted by my examiners.

I authorize Ryerson University to lend this thesis to other institutions or individuals for the purpose of scholarly research.

I further authorize Ryerson University to reproduce this thesis by photocopying or by other means, in total or in part, at the request of other institutions or individuals for the purpose of scholarly research.

I understand that my thesis may be made electronically available to the public.

GIOVANNA S. GONZALES CALIENES 


\title{
ASSESSMENT OF ONTARIO'S FEED-IN TARIFF FOR RENEWABLE ENERGY POLICY: THE CASE OF SOLAR PV TECHNOLOGY
}

\author{
Giovanna Salome Gonzales Calienes \\ Master of Applied Science, Environmental Applied Science and Management, \\ 2014 \\ Ryerson University
}

\begin{abstract}
Promotion of renewable energy sources is associated with relieving climate change and energy security issues. In this context, solar energy is one of the most suitable renewable energy technologies to be technically viable to support a sustainable and renewable energy industry in Ontario, supported by a feed-in tariff (FIT) policy program. The purpose of this thesis was to develop an integrated assessment of the likely effectiveness and sustainability performance of Ontario's FIT solar PV program using a qualitative analysis through an international comparative policy analysis and a set of criteria evaluation; and a quantitative analysis using an economic evaluation of the solar PV value chain in Ontario to obtain the resulting costs/benefits to the province using the Life Cycle Sustainability Assessment (LSCA) framework and the cost/benefit approach. Based on the results of the integrated evaluation, renewable energy policy implications will be determined including the effectiveness of regulatory incentives.
\end{abstract}




\section{ACKNOWLEDGEMENTS}

I would like to express my deepest gratitude to my supervisor Dr. Philip Walsh for his valuable support and guidance in helping me to go through all the difficulties in my thesis work. His accurate suggestions and guidance have greatly enhanced my knowledge and skills in research and have significantly contributed to the completion of this graduate research.

In addition, I would like to thank to my committee chair, Dr. Ronald Pushchack, and my committee members, Dr. Cory Searcy, and Dr. Vanessa Magness, who have reviewed my thesis and have given me valuable comments that enabled me to improve my thesis.

Finally, I would like to express my deep appreciations to my family, relatives, and friends who have motivated and supported me during these years of study. 


\section{DEDICATION}

I dedicate this Thesis research to my family. A special gratitude to my beloved parents, Luis and Irma Gonzales, whose unconditional support and words of encouragement motivated me throughout the process. My sisters Rossina, Lydia and Katherine have been my best cheerleaders.

I also dedicate this graduate research work to my loving husband Paolo Ignacio, who has been there for me throughout the master program, and my cherished children Francesco and Isabella, who gave me the extra motivation to finish my Thesis. 


\section{TABLE OF CONTENTS}

AUTHOR'S DECLARATION ................................................................................... ii

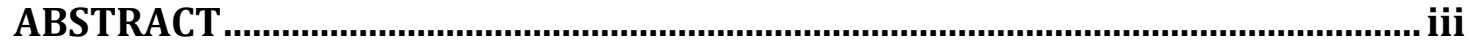

ACKNOWLEDGMENTS .............................................................................................. iv

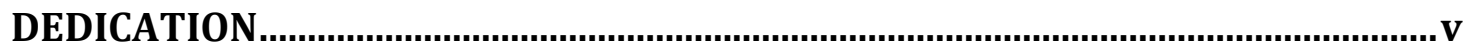

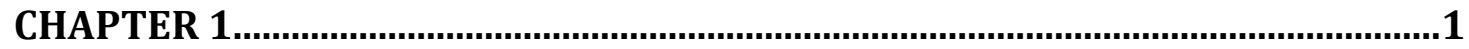

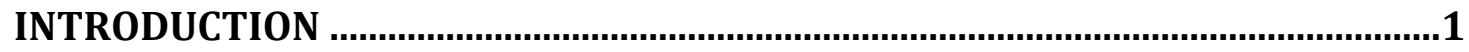

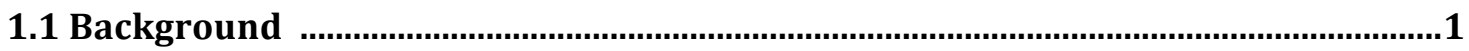

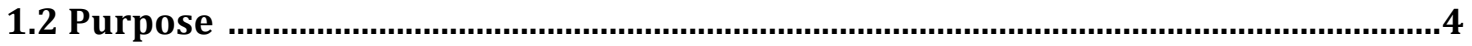

CHAPTER 2

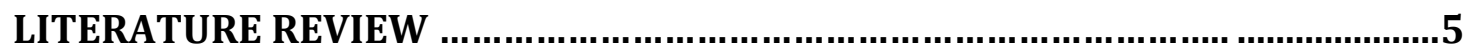

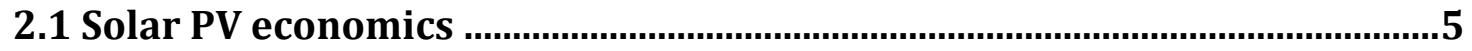

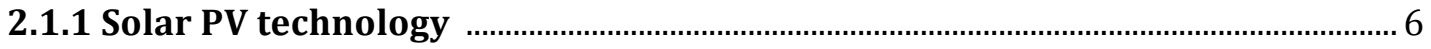

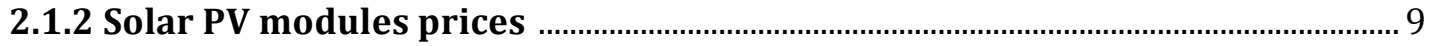

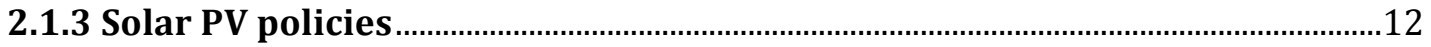

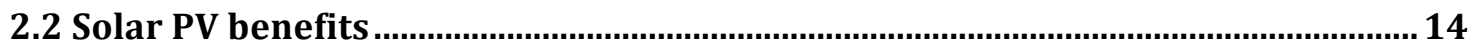

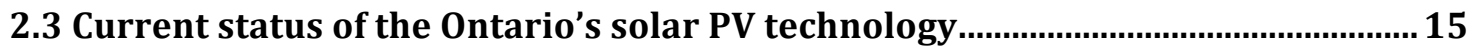

2.4 Ontario's Renewable Energy Policy Overview ……................................................ 18

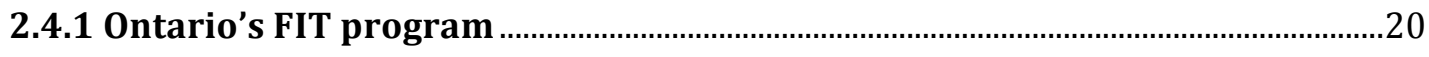

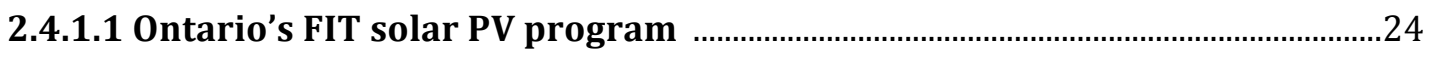

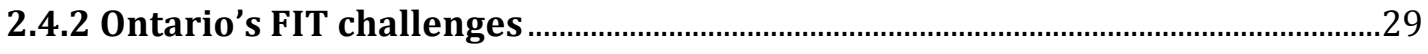

2.5 Comparative policy analysis and lesson drawing.................................................. 29

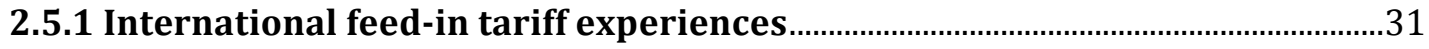

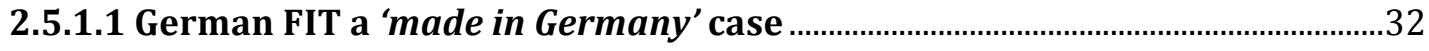

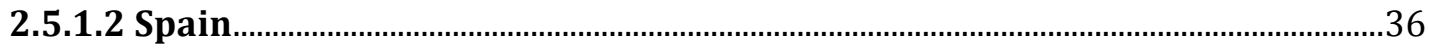

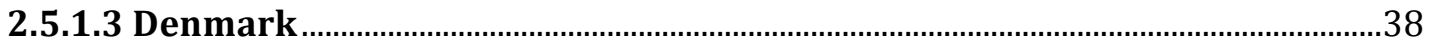

2.6 Assessment of effectiveness and sustainability for solar PV projects.................. 39

2.7 Life Cycle Sustainability Assessment (LCSA) ........................................................... 41

2.7.1 Life Cycle Assessment (LCA) ....................................................................................42 
CHAPTER III

RESEARCH QUESTIONS

CHAPTER IV.

RESEARCH METHODS

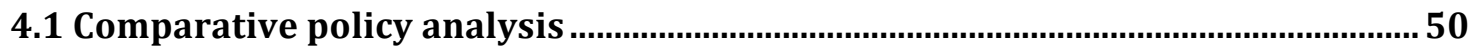

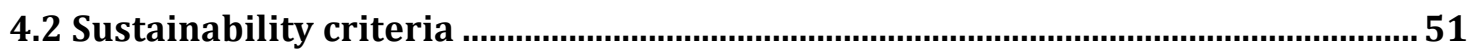

4.3 Case study: Analysis of the value chain of Ontario's FIT solar PV system: ..........53

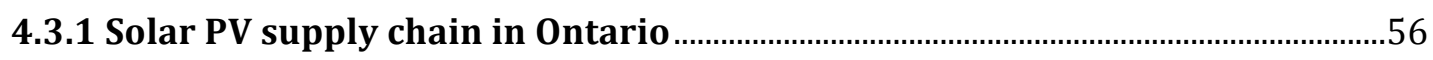

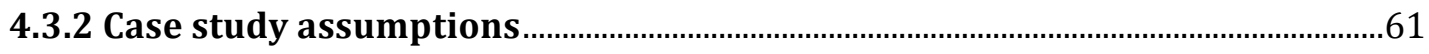

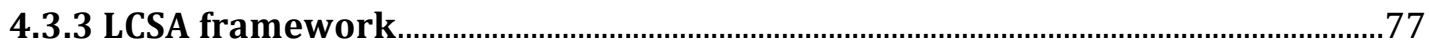

4.3.3.1 (environmental) LCA approach ................................................................................

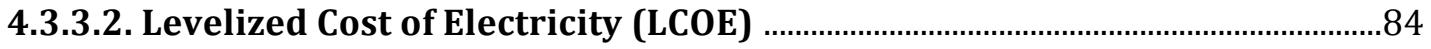

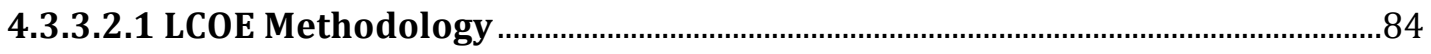

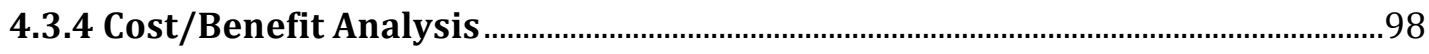

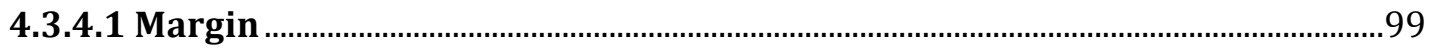

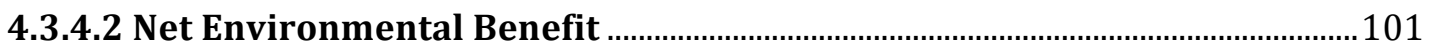

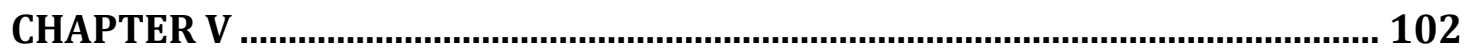

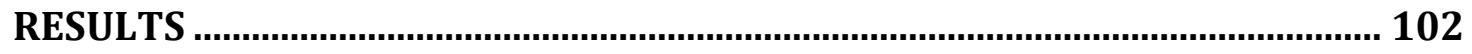

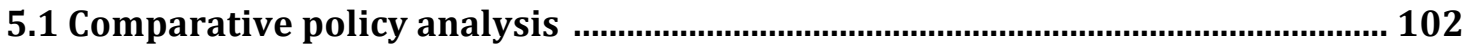

5.1.1 Comparison with Germany FIT program ............................................................ 104

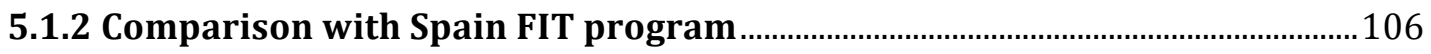

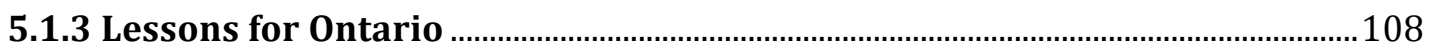

5.2 Case study: Analysis of the FIT solar PV value chain in Ontario ......................... 110

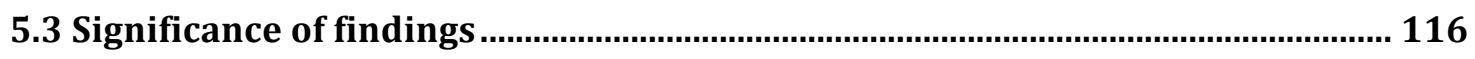

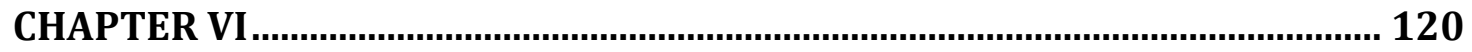

CONCLUSIONS, IMPLICATIONS AND FUTURE RESEARCH........................... 120

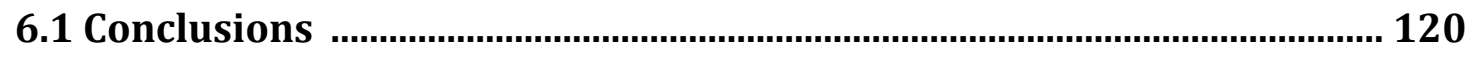

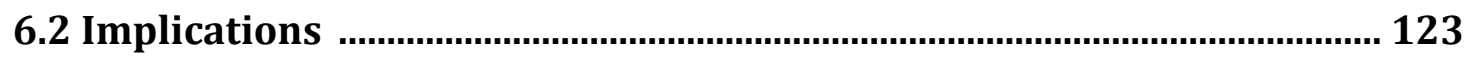




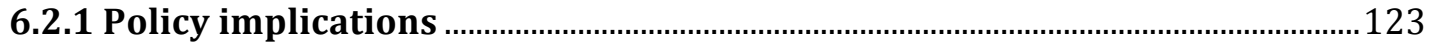

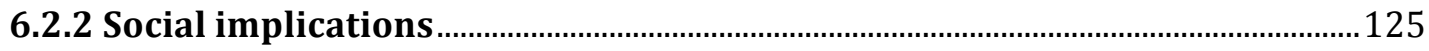

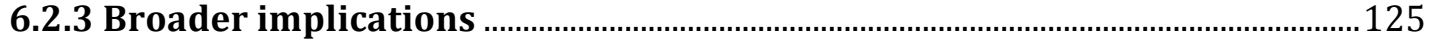

6.3 Future Research .................................................................................... 126

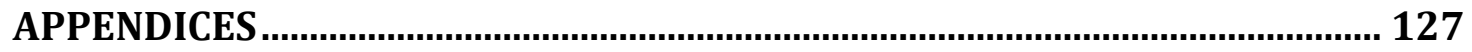

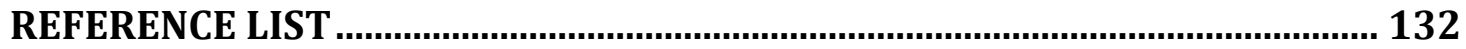




\section{LIST OF TABLES}

Table 1 Ontario's Feed-in tariff schedule ...................................................... 21

Table 2 FIT solar PV ground-mounted contract holders ................................. 27

Table 3 Sustainability indicators for electricity generation technologies ..40

Table 4 Set of sustainability indicators for solar PV technology ...................52

Table 5 PV module manufacturers located in Ontario .................................. 58

Table 6 Weighted Average FIT solar PV contracted capacity $\left(\mathrm{kW}_{\mathrm{AC}}\right) \ldots . . . . . .62$

Table 7 FIT 1.0 solar PV rooftop and ground-mounted contract offers .......63

Table 8 FIT 2.0 solar PV rooftop and ground-mounted contract offers ...... 63

Table 9 Weighted Average FIT solar PV rooftop contracted capacity $\left(\mathrm{kW}_{\mathrm{AC}}\right)$

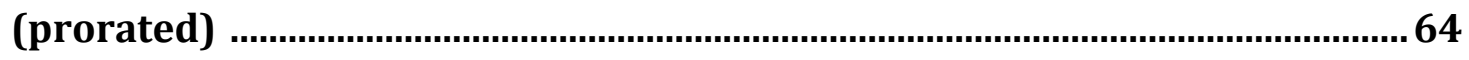

Table 10 Weighted Average FIT solar PV ground-mounted contracted

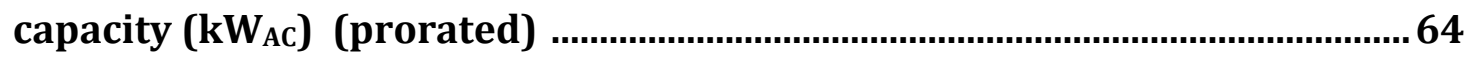

Table 11 FIT 1 solar PV ground-mounted contract offers by region (2009-

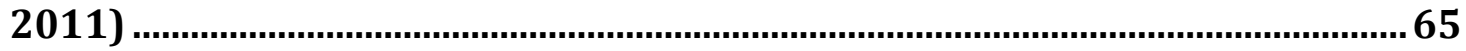

Table 12 FIT 2 solar PV rooftop contract offers by region (2012 - 2013) ....66

Table 13 Summary of the assumptions of the Ontario's FIT solar PV system

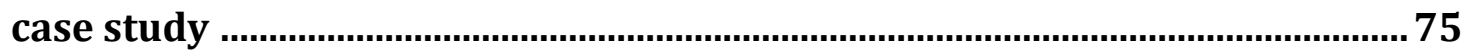

Table 14 Harmonized parameters and its standard values for multi-

crystalline Si PVs ....................................................................................... 81

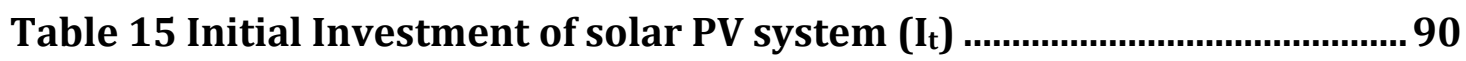

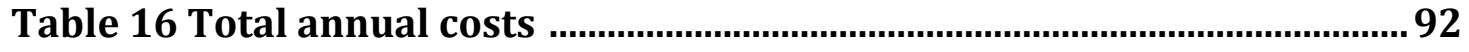

Table 17 Financial assumptions for a typical renewable energy project .... 94

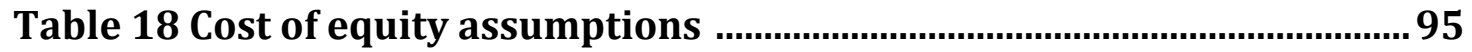

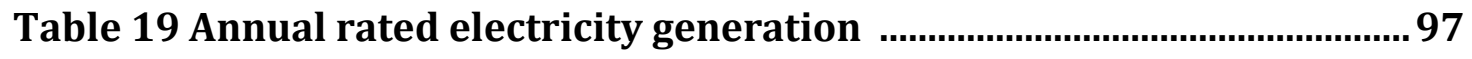

Table 20 Weighted Average FIT solar PV rate (CADc/kWh

Table 21 Weighted Average FIT solar PV rooftop rate (CADc/kWh $\mathrm{kC}_{\mathrm{AC}}$ -

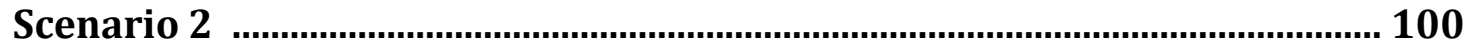

Table 22 Weighted Average FIT solar PV ground-mounted rate (CADc/kWh $\mathbf{k C}_{\mathrm{AC}}$ - Scenario 3 100 
Table 23 Level of accomplishment by FIT policy comparator.....................104

Table 24 International rate comparison (CADc/ kWh) .................................. 105

Table 25 LCOE Calculation (Scenario 1) .................................................... 111

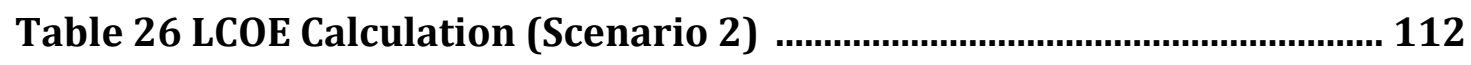

Table 27 LCOE Calculation (Scenario 3) ........................................................ 113

Table 28 Environmental Benefits and Environmental Costs ..................... 114

Table 29 Cost/Benefit results for the Ontario's FIT solar PV system case

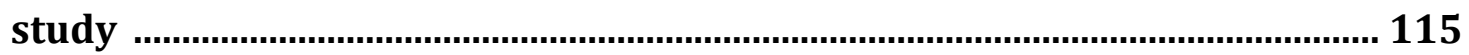




\section{LIST OF FIGURES}

Figure 1 Global cumulative solar PV installed capacity, 1995-2012 ..............6

Figure 2 Learning curves of renewable electric technologies ........................8

Figure 3 Global average solar PV module prices, all PV technologies

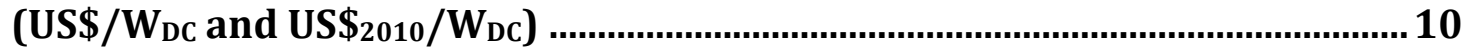

Figure 4 Evolution of solar PV system installed cost $\left(U S \$ 2010 / W_{D C}\right) \ldots . . . . . . . .10$

Figure 5 Levelized cost of electricity generation by technology

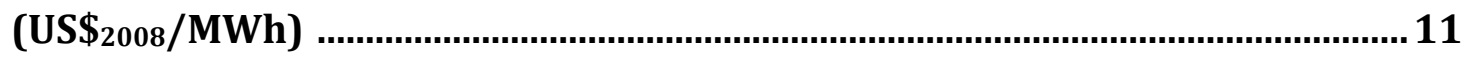

Figure 6 Policy market incentives proportionate market share by $2012 \ldots 13$

Figure 7 Average Cost of Standard PV Modules and Balance of System Cost

in Canada, 2004-2012 .................................................................................... 17

Figure 8 Ontario electricity generation forecast $2013-2032$ (TWh) $\ldots . . . . . .19$

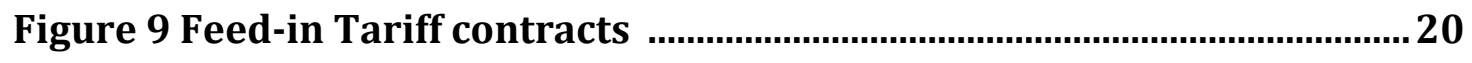

Figure 10 Total FIT solar PV contracted capacity .......................................... 25

Figure 11 Total FIT solar PV contract offers by type of installation (FIT 1

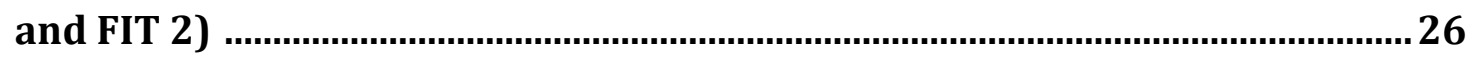

Figure 12 Evolution of FIT rooftop solar PV price schedules 2009-2014

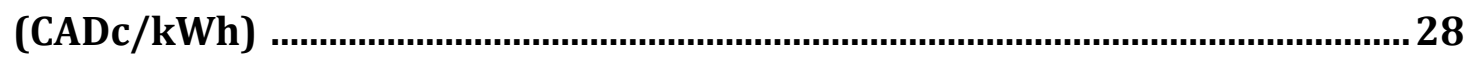

Figure 13 Evolution of FIT ground-mounted solar PV price schedules 2009-

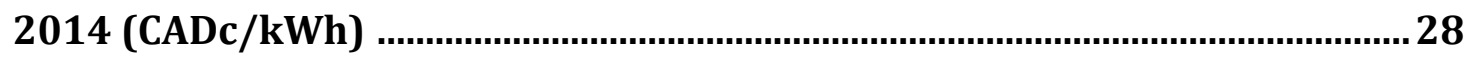

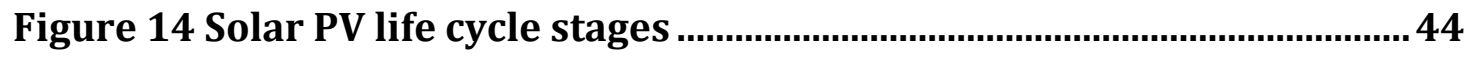

Figure 15 Research methods: main steps .................................................50

Figure 16 Case study research methods: LCSA framework and cost/benefit

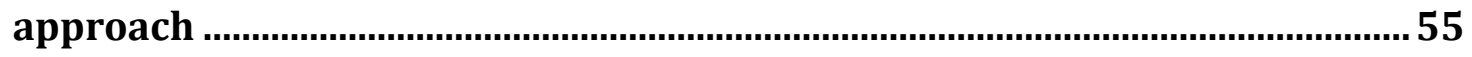

Figure 17 Typical solar PV system supply chain in Ontario ...........................60 


\section{LIST OF APPENDICES}

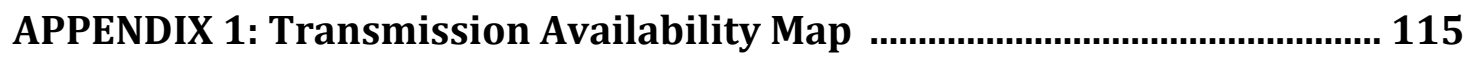

APPENDIX 2: Solar PV Potential and Insolation ............................................. 116

APPENDIX 3: LCOE Calculation (Scenario 1) …….......................................... 117

APPENDIX 4: LCOE Calculation (Scenario 2) ……............................................ 118

APPENDIX 5: LCOE Calculation (Scenario 3) ................................................... 119 


\section{LIST OF ACRONYMS}

AC: Alternate current

BOS: Balance of system

CanSIA: Canadian Solar Industries Association

DC: Direct current

EEG: Renewable Energy Sources Act

EPC: Engineering, Procurement and Construction

FIT: Feed-in Tariff

GEIA: Green Energy Investment Agreement

GHG: Greenhouse gas

GTA: Great Toronto Area

GW: Gigawatt

kW $W_{\text {DC: Kilowatt direct current }}$

$\mathbf{k W}_{\text {Ac: }}$ Kilowatt alternate current

LCA: Life cycle assessment

LCOE: Levelized cost of electricity

LSCA: Life cycle sustainability assessment

MWh: Megawatt-hour

NRCan: National Resources Canada

NREL: National Renewable Energy Laboratory

O\&M: operating and maintenance

OPA: Ontario Power Authority

PV: Photovoltaic

R\&D: Research and Development

RE: Renewable energy

RES: Renewable energy sources

RET: Renewable energy technology (ies)

RPS: Renewable energy portfolio standards

STC: Standard testing conditions

TWh: Terawatt-hour

WACC: Weighted average cost of capital

$\mathbf{W}_{\text {p: Watt peak }}$

WT0: World Trade Organization 


\section{CHAPTER 1 \\ INTRODUCTION}

\subsection{Background}

Climate change issues associated with fossil fuels have forced many countries around the world to adopt green energy policies to promote the use of renewable energy sources (RES) and face increasing energy demand. In this context, renewable energy technologies (RET) development has taken different ways across countries, supported by a range of policy frameworks, depending on the particular national context, including feed-in tariff (FIT), renewable energy portfolio standards (RPS), and renewable energy standard offer program (RESOP). FIT and RPS are the most beneficial programs for promoting development of renewable energy technologies implemented around the world (Palmer and Burtrow 2005; Solangi et al. 2011).

One of the most widely used incentive rate structures for stimulating development of renewable energy (RE) technologies is the feed-in-tariff (FIT) program (REN21 2013), "a pricing policy, guaranteeing RE generators a fixed price for the electricity they produce" (Lipp 2007; Mabee et al. 2011) aimed to promote renewable energy technologies and the development of the renewable energy industry. Zhao et al. (2013) researched whether the effectiveness of the renewable energy (RE) policy varies by policy instrument and by RE source for generating electricity using a dataset of 122 countries over the period of $1980-$ 2012. They found that only a FIT is effective in promoting the development of all 
types of RE sources considered in their research, including biomass and waste, solar, tide and wave, and wind. The effectiveness of a FIT program was higher on solar energy.

Indeed, one of the most promoted RET by FIT programs is solar photovoltaic with a high potential for market penetration, easy installation and declining cost of technology (Muneer et al. 2011). According to the 2013 BP Statistical Energy Review, solar PV capacity has grown more than ten-fold over the past 5 years. The world cumulative installed solar energy capacity was 100 GW in 2012, a change of 43\% compared to 2011 (REN21 2013; BP 2013). The annual growth rate of the global solar PV deployment was more than $40 \%$ over the period of 2000 to 2010 , due to both technological improvements that have decreased manufacturing costs by 100 times and a wide range of government incentives for consumers and developers (Branker et al. 2011). Even though its overall share of renewable power remains low (8.9\%), 2012 confirmed the arrival of solar power at scale, contributing $24.4 \%$ of the growth of global renewable power.

In the particular case of Ontario, its renewable energy policy is supported by the Green Energy and Green Economy Act (2009) and the FIT program, the first large-scale FIT program in North America, "Not since the US Congress passed (the Public Utility Regulatory Policy Act) in 1978 has a single policy had the potential for such wide-ranging influence on energy policy (in North America) 
as Ontario's Green Energy Act' (Mendonca et al. 2009, p.91). Besides, the FIT mechanism was chosen because of its potential to drive the growth of the renewable energy industry and for generating conditions that reduce (but not eliminate) risk and improve investment security (Mabee et al. 2011; Stokes 2013).

Ontario's Government has adopted solar development as an alternative renewable energy source. Solar energy is one of the most suitable RETs that is technically viable to support a sustainable and renewable energy industry in Ontario. Mainly because of its energy potential in Ontario with more than $30 \mathrm{GW}$ of viable solar potential on rooftops and $90 \mathrm{GW}$ of potential for ground based solar farms on marginal land in south-eastern Ontario alone, and lately its massive growth with the associated decrease in costs. In this context, when Ontario's FIT was launched in 2009 it was predicted to encourage rooftop PV deployment as a result of its sliding-scale pricing structure (Branker and Pearce 2010; Wiginton et al. 2010). Ontario's 2009 FIT was intended to increase demand and procure small scale solar PV while receiving the highest tariff rate of CAD $\$$ 0.80/kWh (Ontario 2009b). However, a high level of monetary incentive does not assure the development and deployment of solar PV projects or solve issues such as grid parity (Branker and Pearce 2010). 


\subsection{Purpose}

The objective of this graduate research was to provide an answer to the following questions: As a policy instrument, how has Ontario's FIT program worked to promote solar PV technology in Ontario?; what criteria should be used to assess the effectiveness and sustainability of Ontario's FIT with a focus on solar PV?; and what are the resulting costs/benefits to the province?.

The method used to answer the research questions was an integrated assessment of the likely effectiveness and sustainability performance of the solar PV technology in Ontario using a qualitative analysis through an international comparative policy analysis and a set of criteria evaluation; and a quantitative analysis using an economic evaluation of the solar PV value chain in Ontario to obtain the resulting costs/benefits to the province using the Life Cycle Sustainability Assessment (LSCA) framework and the cost/benefit approach. Based on the results of the integrated evaluation, renewable energy policy implications were determined including the effectiveness of regulatory incentives. 


\section{CHAPTER 2 \\ LITERATURE REVIEW}

\subsection{Solar PV economics}

The Solar PV industry has developed dramatically in the last five years (as shown in Figure 1) due to technological improvements resulting in price reductions and government regulatory incentives for renewable energy development and deployment. The carbon credit markets have emerged as a consequence of the (negative) environmental externalities of fossil fuels, essentially GHG emissions. Although these carbon credit markets are considered drivers of solar PV technology deployment, the scale of incentives provided by the current $\mathrm{CO}_{2}$ market instruments such as the Clean Development Mechanism of the Kyoto Protocol and the Cap-and-Trade of European Union Emissions Trading Scheme is still limited (IEA 2011; Timilsina et al. 2012).

The description of the main drivers of this recent solar PV energy growth provides an understanding of the current and future development and large-scale deployment of this type of renewable energy technology (Timilsina et al. 2012). 
Figure 1 Global cumulative solar PV installed capacity, 1995 - 2012

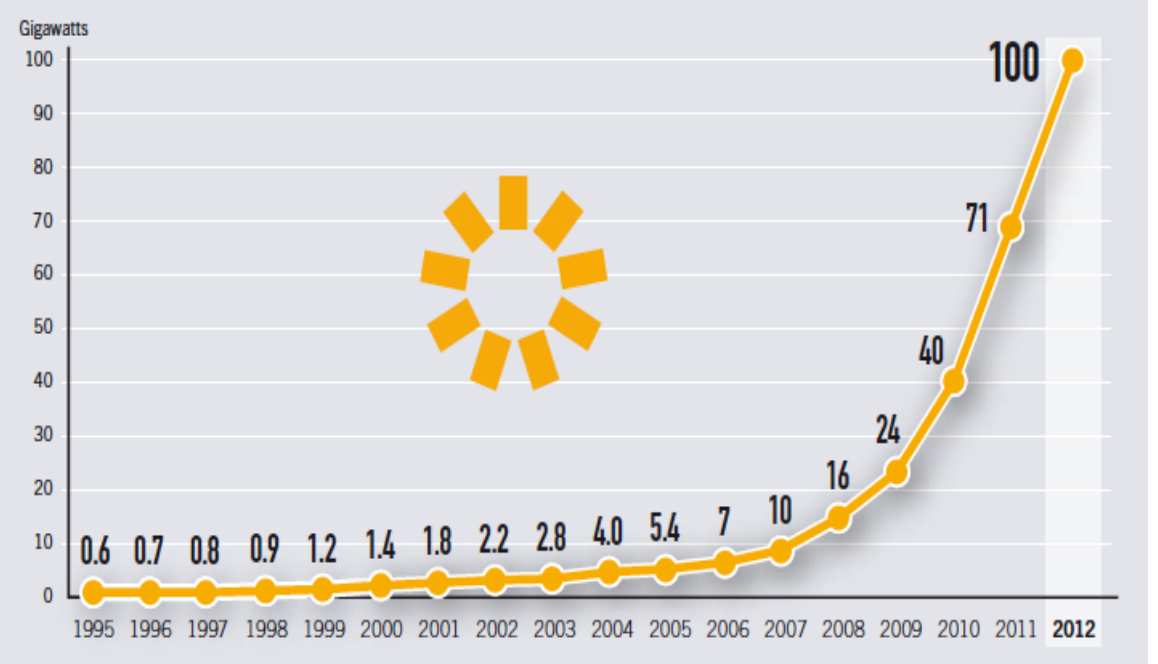

Source: REN21 2013

\subsubsection{Solar PV technology}

Solar PV technology is part of several solar energy technologies including solar thermal for heating and cooling, concentrated solar power and solar fuels. Solar PV cells were invented at Bell Labs in the United States (US) in 1954. This technology "converts radiant energy contained in light quanta into electrical energy when light falls upon a semiconductor material, causing electron excitation and strongly enhancing conductivity" (Timilsina et al. 2012).

Solar PV systems can be used for off-grid and on-grid applications, the latter represented $85 \%$ of the market in 2010 (Timilsina et al. 2012). A typical solar PV system connected to the grid consists of the PV module and the balance of system (BOS) components for racking/mounting the PV modules and converting the generated electricity from direct current (DC) to alternate current 
(AC) electricity for usage in the power grid (Fthenakis and Kim 2011).

The basic design element of a solar PV system is the nominal power capacity of the PV module. This capacity is rated by manufacturers either in watts direct current $\left(W_{D C}\right)$ or in watts peak current $(\mathrm{Wp})$. These ratings correspond to standard testing conditions (STC): $1000 \mathrm{~W} / \mathrm{m} 2$ irradiance with normal incidence, $25{ }^{\circ} \mathrm{C}$ module temperature, and air mass of 1.5 (McKenney et al. 2008; Branker et al. 2011; Hernandez-Moro and Martinez-Duart 2013).

Using the concept of learning curves that plot cost as a function of cumulative production on a double logarithmic scale, Timilsina et al. (2012) noted that there is a constant relationship between cost reduction percentage and cumulative installed capacity. The solar PV technology (in Figure 2) has the highest learning curve among electricity generation technologies, including other renewable electricity technologies such as wind power with a learning rate of $8 \%$. The PV learning rate for PV modules is about $21 \%$ on average over 34 years (1976 to 2010). This means that each doubling of cumulative installed capacity has led to a cost decrease of about $21 \%$. The PV learning rate for PV systems is about 12.5\% (IEA 2011; Timilsina et al. 2012). 
Figure 2 Learning curves of renewable electricity technologies
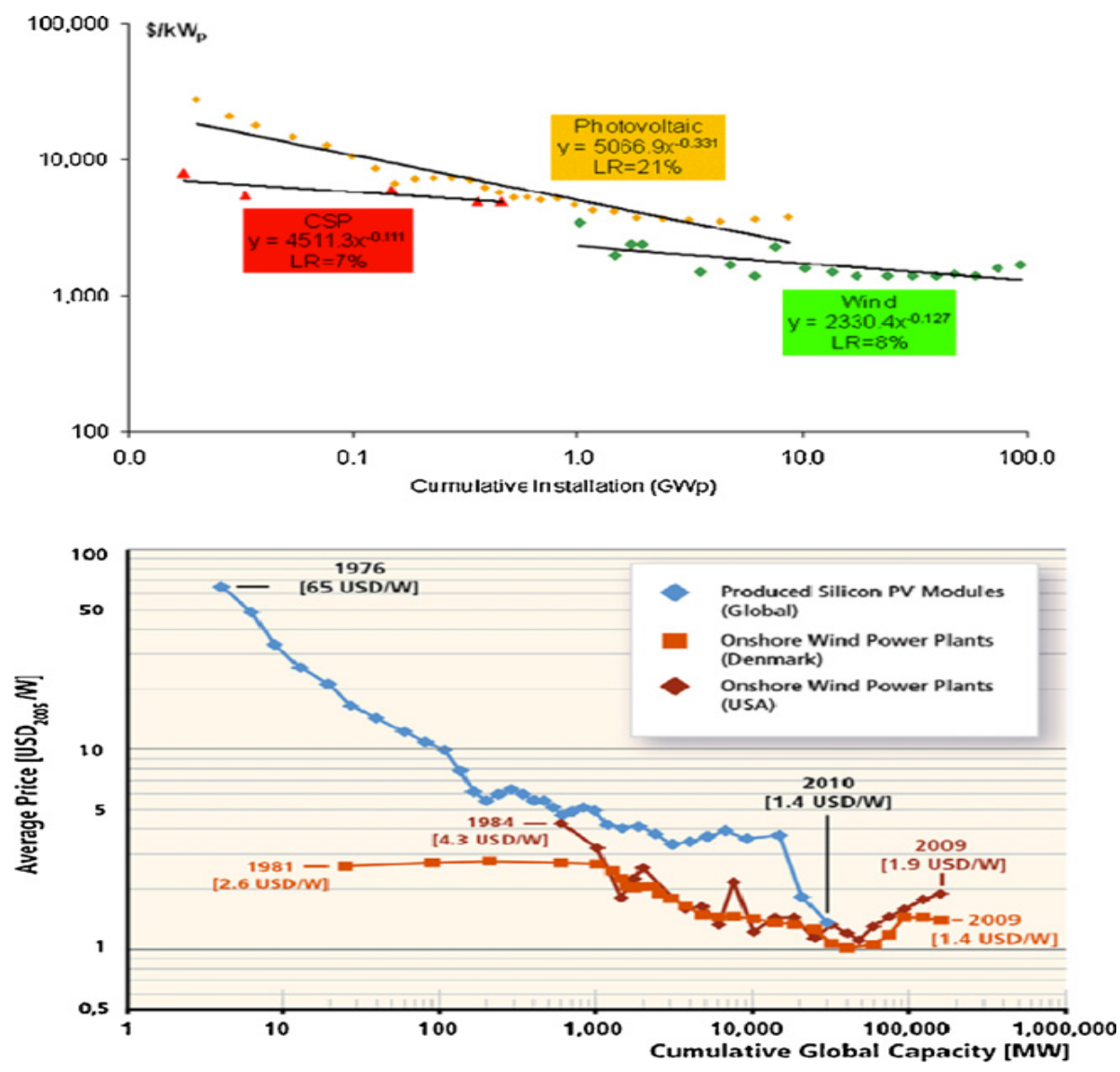

Source: Timilsina et al. 2012

There are several types of solar PV module technologies in the market, among them the crystalline silicon (mono-crystalline and multi-crystalline) and thin film (amorphous, and CdTe) technologies, that have the major market shares. A Crystalline silicon wafer based (c-Si) PV module is the technology that has been established on the market for the longest time; it leads the market with 85\% of the shares in 2010 and $84 \%$ in 2013 (Branker et al. 2011; IEA 2011; Colville 2013). c-Si PV cells use two types of silicon: mono-crystalline and multicrystalline. Although mono-c silicon PV has higher efficiencies than multi-c 
silicon, the multi-c Si solar PV dominates the PV module technologies market, with a share of $56 \%$ in 2013. Multi-c Si solar PV is likely more successful because of its lower manufacturing costs (Hsu et al. 2012; Colville 2013).

\subsubsection{Solar PV modules prices}

Solar manufacturing prices have been dropping rapidly in recent years with economies of scale through turnkey manufacturing facilities and industrial symbiosis, due to both technological improvements and the effect of the learningby-doing process (Branker et al. 2011; Hernandez-Moro and Martinez-Duart 2013; Reichelstein and Yorston 2013). The cost of solar PV technology has dropped significantly over the last 30 years. For instance, the average cost of PV modules (in Figure 3), has fallen from US\$23/WDC in the mid-1980s to US\$2.36/ $W_{D C}$ in 2010. Furthermore, the cost of installing solar PV systems (in Figure 4), which includes BOS component costs and labour costs, decreased from US $\$ 11 / W_{D C}$ in 1998 to about US $\$ 6 / W_{D C}$ in 2010 (NREL 2011; Timilsina et al. 2012). 
Figure 3 Global average solar PV module prices, all PV technologies (US $\$ / W_{p}$ and US $\left.\$ 2010 / W_{p}\right)$

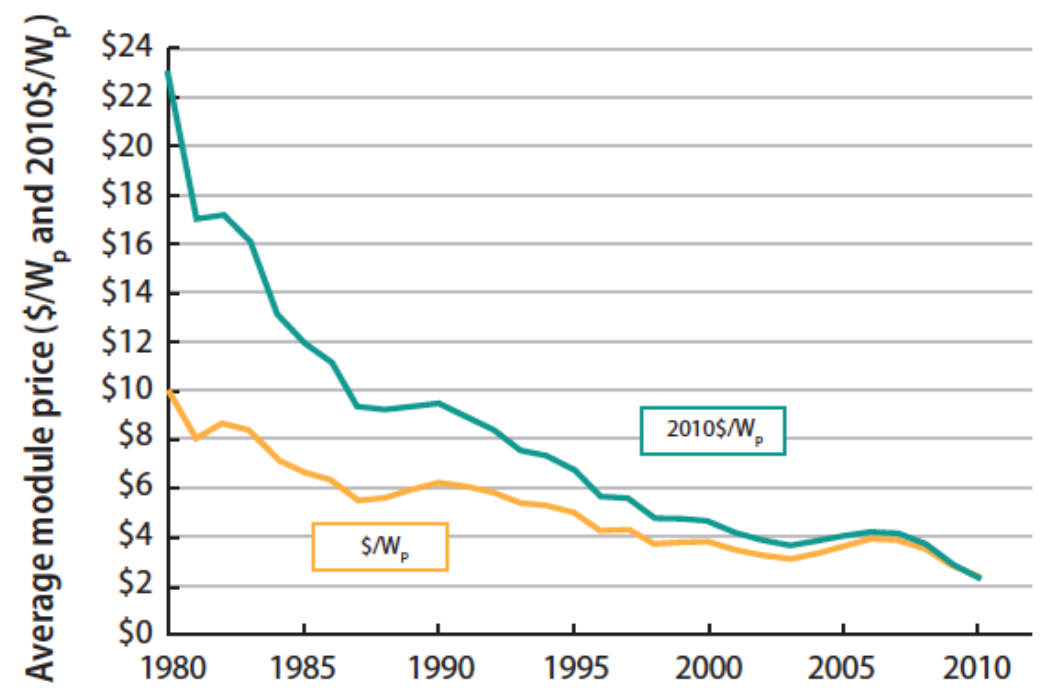

Source: NREL 2011.

Figure 4 Evolution of solar PV system installed cost $\left(U S \$_{2010} / W_{D C}\right)$

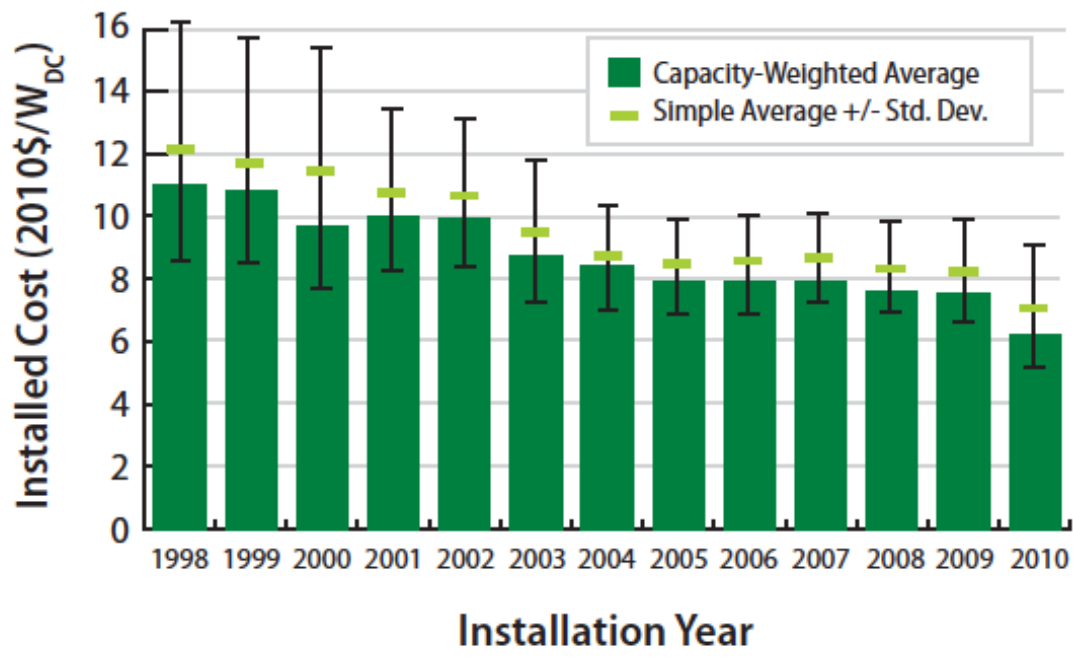

Source: NREL 2011. 
The levelized cost of electricity (LCOE) is a standard metric to compare the costs of different electricity generation technologies. Comparing the LCOEs of solar PV technology versus the conventional and renewable electricity generation technologies (in Figure 5), solar PV system costs remain higher and more economically unattractive (in a range of 192-719 US\$/MWh) compared to other technologies. This holds true despite the significant decline in PVs system capital costs, and if it is assigned a benefit value for avoiding the environmental damage cost of US\$100/MWh for fossil fuel technologies (Timilsina et al. 2012).

Figure 5 Levelized cost of electricity generation by technology

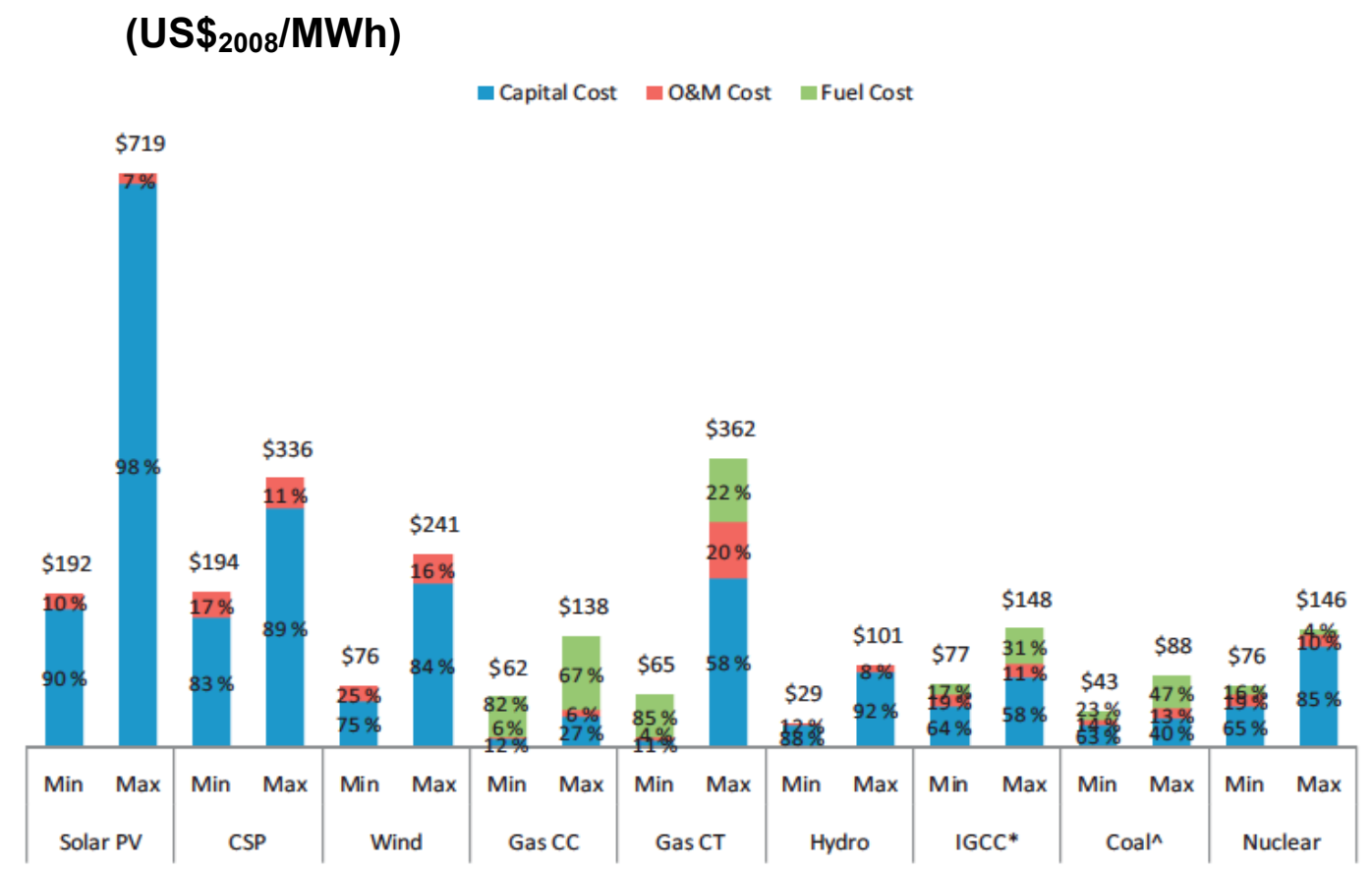

Note: * IGCC with carbon capture and storage. ^ Supercritical coal.

Source: Timilsina et al. 2012. Assumes $10 \%$ of discount rate. 
Additionally, solar PV should become a major energy supply contributor if this technology achieves grid parity given that conventional-generated electricity prices are rising and solar PV installed prices are falling. 'Grid parity' refers "to the lifetime generation cost of the electricity from PV being comparable with the electricity prices for conventional sources on the grid" that is the industry average for solar PV electricity generation against the average electricity price for a given country (Branker et al. 2011). The first level of grid parity should be reached when the solar generation costs are approximately equal to retail electricity prices. Several studies considered that while grid parity could be reached in the next 5 to 10 years, currently solar PV technology is not yet competitive with conventional electricity generation technologies; this is the major barrier for a large-scale deployment of this technology (Branker et al. 2011; Timilsina et al. 2012; Hernandez-Moro and Martinez-Duart 2013; Reichelstein and Yorston 2013).

\subsubsection{Solar PV policies}

Policy instruments support the development of renewable technology mainly to reach cost competitiveness. The most effective instruments to promote solar PV technology are the FITs, especially in leading countries such as Germany, Spain, Italy, China, and Japan, who provide incentives to investors by guaranteeing reasonable rates of return on investment with $100 \%$ grid access and power purchase. In addition, the renewable energy portfolio standards (RPS) and federal/ state incentives, such as in the US, establishes a renewable energy 
penetration target in the total electricity supply mix at national and state levels through a trading mechanism to buy/sell renewable electricity contents (Timilsina et al. 2012). For instance, the main drivers of PV market development are shown in Figure 6. The FIT represented $61 \%$ of the total policy solar PV market incentives and enablers as of the end of 2012, while RSP and subsidies together were $26 \%$ of the total policy mechanisms.

Figure 6 Policy market incentives proportionate market share by 2012

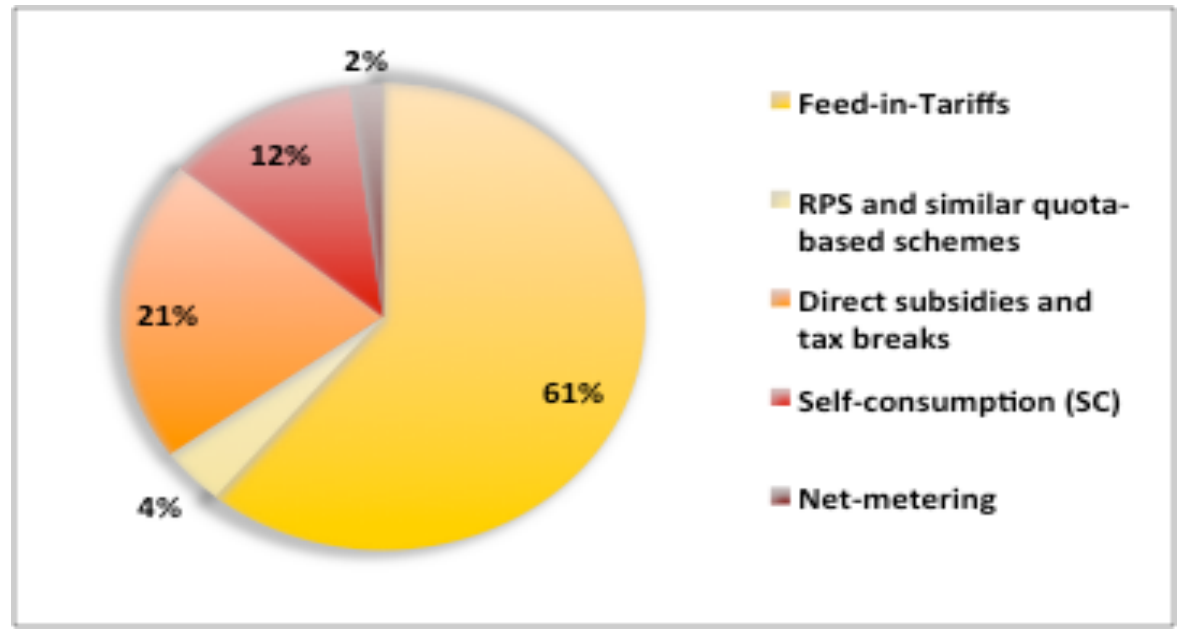

Source: Masson 2014

Currently solar PV policy is still a policy-driven market to achieve grid competitiveness. For instance, decreasing political support for solar PV has resulted in a reduced market in Spain. However, as grid parity is achieved the solar PV policy framework should evolve towards promoting self-sustained markets, with the gradual phase-out of economic incentives, but continuing grid access guarantees and sustained research and development (R\&D) support (IEA 2010; EPIA 2014). 


\subsection{Solar PV benefits}

Vergara et al. 2013 and IRENA 2014a reported on a holistic analysis related to the key benefits of the deployment of solar PV technology as follows:

I. Potential socio-economic benefits related to attracting new investments, implement local content requirements towards developing a local solar PV industry, creating direct and indirect jobs, and providing an indigenous energy resource without an expiration date.

II. Positive environmental impact as a zero carbon option is one of the most effective strategies to reduce greenhouse gas (GHG) emissions. It provides opportunities to offset carbon credits in the available $\mathrm{CO}_{2}$ trading markets. Additionally, solar PV energy helps decrease the negative impacts on human health due to air pollution from nitrogen oxides, sulfur oxides, and particulate matter as a consequence of electricity generation from fossil fuels.

III. Solar PV technology contributes to long-term energy security. Since solar PV technology ensures access to reliable energy at steady prices it supports economic growth. National energy security and energy sovereignty has become an important concern for many nations worldwide. Solar PV energy can be used in any country in the world, which makes it a very strategic domestic energy option. 
IV. Demand for education and training in solar technology is increasing. Assuming the current global trends in solar PV energy deployment continue, the demand for skilled human resources is expected to continue to grow. Therefore, research technological development and innovation activities will become increasingly vital as part of value creation of this technology and sustained economic growth.

\subsection{Current status of the Ontario's solar PV technology}

The Province of Ontario leads the country in solar PV investment. As of December 2013 , the cumulative solar PV installed capacity was $1,020 \mathrm{MW}_{\mathrm{AC}}$ with a breakdown of $470 \mathrm{MW}_{\mathrm{AC}}$ under the Renewable Energy Standard Offer Program (RESOP), $390 \mathrm{MW}_{\mathrm{AC}}$ under the FIT program and $160 \mathrm{MW}_{\mathrm{AC}}$ under the microFIT program. The total amount of installed and under development solar PV capacity in Ontario is approximately 2,138 MW $\mathrm{MW}_{\mathrm{AC}}$. In Ontario's 2013 Long Term Energy Plan (LTEP), the government reinforced its commitment to $900 \mathrm{MW}_{\mathrm{AC}}$ of additional capacity including 4 years of annual procurement targets; $50 \mathrm{MW}_{\mathrm{AC}}$ under microFIT ( $<10 \mathrm{~kW}_{\mathrm{AC}}$ ) and $150 \mathrm{MW}_{\mathrm{AC}}$ of FIT (projects up to $500 \mathrm{~kW}_{\mathrm{AC}}$ ). There was a further $15 \mathrm{MW}_{\mathrm{AC}}$ FIT procurement in the Unconstructed Rooftop Solar Pilot (URSP) Program for projects on unconstructed buildings (OPA 2013a).

Regarding the PV industry status in Canada, especially in Ontario, the solar PV sector has experienced constant and significant investment over the last 
4 years. As a result, the Ontarian PV module production reached $460 \mathrm{MW}_{\mathrm{DC}}$ in 2012, growing $142 \%$ compared to 2011 , and it is just under half of the total production capacity in the country, which amounted to $976 \mathrm{MW}_{\mathrm{DC}}$ in 2012. More than $90 \%$ of Ontario's total PV module production is crystalline silicon based PV module technology (Luukkonen et al. 2013). Ontario's solar PV incentives have positively influenced Canada's PV market with incremental growth in installations of 25\% per year between 1994 and 2008. In 2010 this growth was 202\%, 49\% in 2011, and $50 \%$ in 2012 (IEA 2013).

Ontario's FIT is observed by the Canadian PV industry as a major stage on the way to developing a competitive, strong Canadian solar industry. Since the cost of electricity increases and the cost of solar turnkey installations decreases, trends indicate that solar PV power will reach grid parity in most jurisdictions in Canada by 2022 (IEA 2013). Additionally, current information from industry shows the average cost per watt of a solar PV module in Canada was 1.15 CAD in 2012 in comparison to $6.18 \mathrm{CAD}$ in 2000 representing an average annual price reduction of $20 \%$ over a 10 -year period (see Figure 7) (IEA 2013). The minimum PV module price obtained in 2012 was $0.85 \mathrm{CAD} / \mathrm{W}_{\mathrm{DC}}$, which was an imported module (Luukkonen et al. 2013). Solar PV module costs currently account for approximately one-third of the total installed, or turnkey, price of average Canadian solar PV projects. The total turnkey price of distributed solar projects $<10 \mathrm{~kW}$ in Canada was CAD $\$ 3$ - CAD $\$ 5 / \mathrm{W}$ in 2012. Aforementioned, 
the dramatic reduction in equipment costs has helped advance the development of the solar PV industry (CanSIA 2014).

Figure 7 Average Cost of Standard PV Modules and Balance of System Cost in Canada, 2004-2012

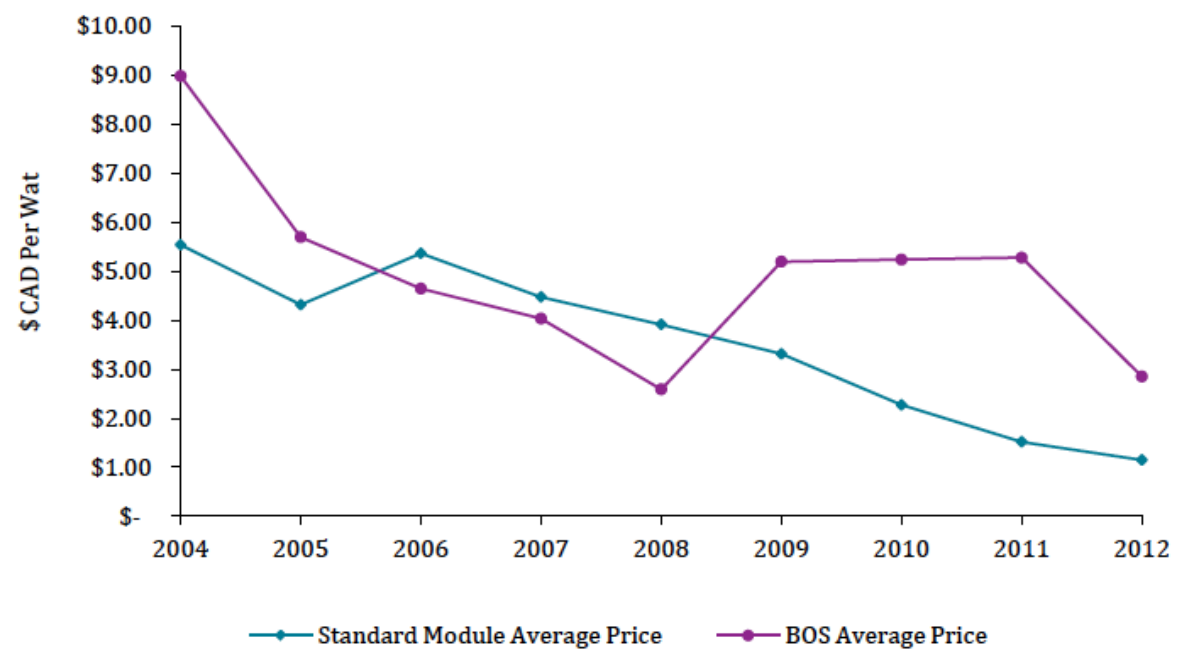

Source: CanSIA 2014

Concerning employment in PV-related areas in Canada, the labour force has increased to an estimated 3,900 in 2012 compared to 2,700 jobs in 2009. The Ontario government plans for 6,000 jobs to be created from the four year FIT procurement targets (OPA 2013a). In 2013, the solar PV module manufacturing industry in the province accounted for over 1,900 full time direct jobs in the design, manufacturing and testing of modules, while the PV inverter industries in the Province provided an additional estimated 250 jobs. Racking, the other major segment of manufacturing, accounts for approximately 700 jobs (IEA 2013). 


\subsection{Ontario's Renewable Energy Policy Overview}

In the context of promoting the use of renewable and sustainable energy in Ontario, the future development of the electricity generation capacity in Ontario is supported by two policies. The first one is the Green Energy and Green Economy Act (2009) that was created to provide a clean, reliable, and sustainable electricity supply by encouraging renewable energy projects, building a strong green economy- 50,000 jobs, promoting energy conservation, and reducing air pollution and greenhouse gases (GHG's) from fossil fuel energy production. As part of the Green Energy Act the FIT program aimed to provide incentives for investment in renewable energy technologies and to increase the capacity of biomass, biogas, wind and solar energy supply to ensure adequate generation and reduce $\mathrm{CO} 2$ emissions. Also, FIT is a cornerstone of the Ontario Government's Green Economy plan that will help to promote new green industries and job creation (Yatchew and Baziliauskas 2011; Moore et al. 2013).

The second one is an updated Long-Term Energy Plan (2013) from the Ontario Power Authority (OPA) that defined the role of fossil, nuclear, and renewable electricity in the province and recommended creating a balanced mix of clean power sources and increasing Ontario's power supply from energy conservation and renewable sources such as wind, solar, and bio-energy to $29 \%$ by 2032, up from the current level of $10 \%$ (see Figure 8) (OPA 2013a). According to the OPA 2013-Q4-progress report on contracted electricity supply, and taking into account both projects under development and in commercial operation, the 
leading RE technology is wind (68\%) while solar has obtained $27 \%$ of the FIT market (see Figure 9). Taken together, these policies set the path for a cleaner electricity generation portfolio in the province that addresses emission reduction, industrial development, and employment goals.

Figure 8 Ontario electricity generation forecast $2013-2032$ (TWh)

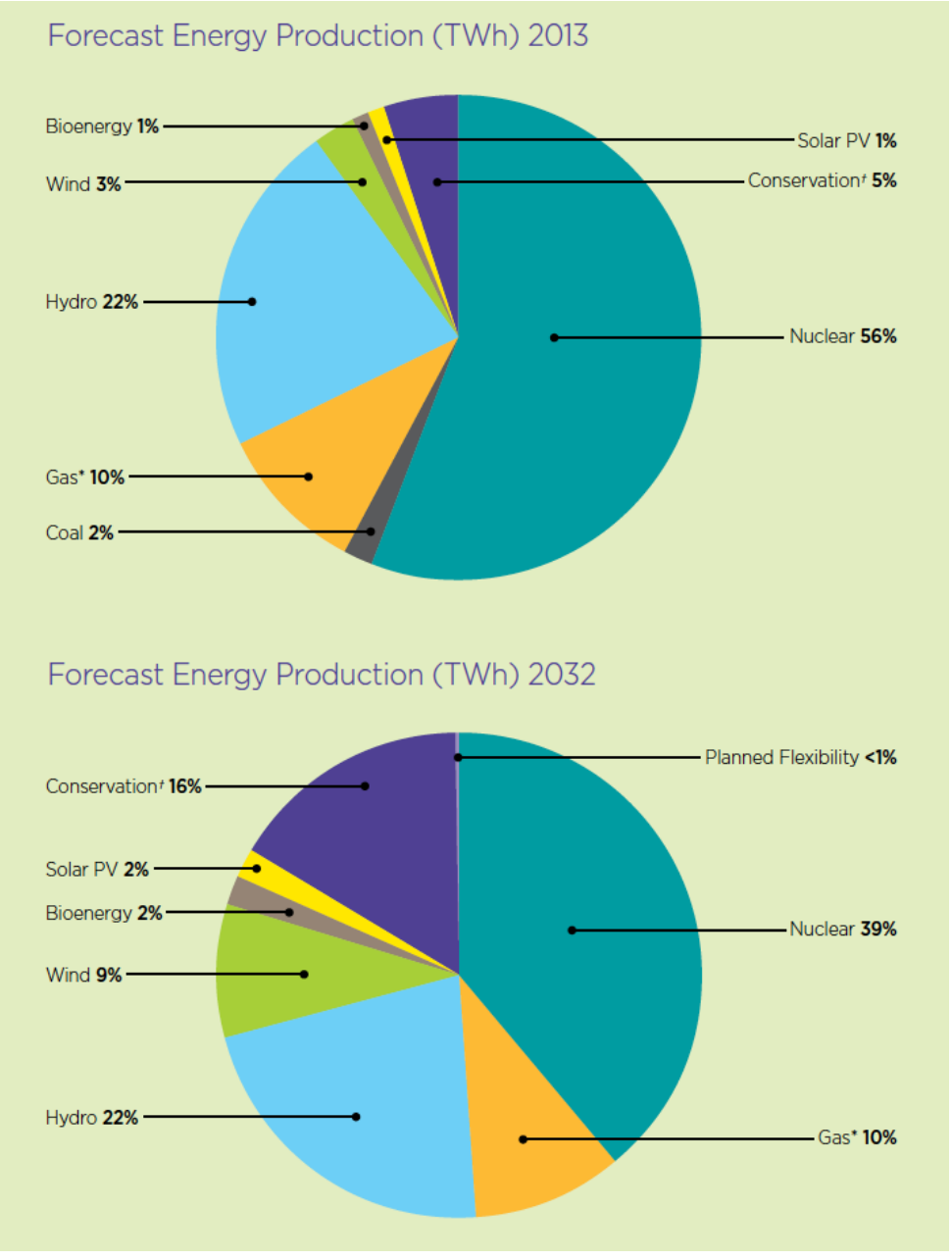

Source: OPA 2013a 
Figure 9 Feed-in Tariff contracts

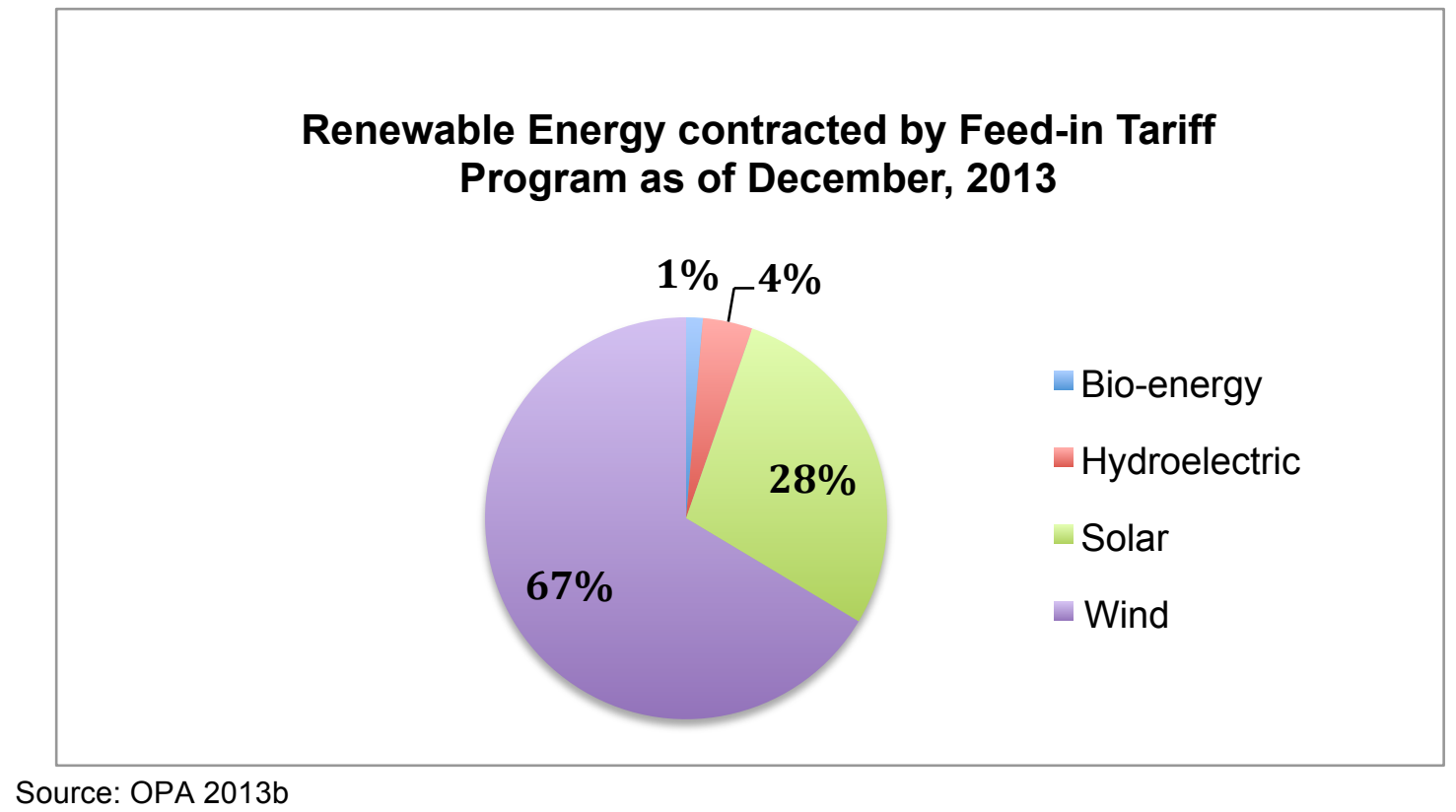

\subsubsection{Ontario's FIT program}

The Feed-in tariff is an incentive based program to encourage investment in renewable energy while promoting economic growth. The main characteristics are: (i) 20-year guaranteed price contract with OPA, (ii) priority access to the grid through local distribution corporations, (iii) two streams: small FIT (10-500 $\mathrm{kW}_{\mathrm{AC}}$ ) and micro FIT (< $10 \mathrm{~kW}_{\mathrm{AC}}$ ), (iv) types of technology: water, solar photovoltaic (solar PV), wind, biogas (anaerobic digestion), biomass (agricultural and forest sources), and landfill gas, (v) supporting programs to help cooperatives, municipalities, public sector entities and First Nations and Métis groups to develop and own renewable energy facilities, and (vi) unique domestic contents. 
OPA is responsible for implementing the FIT program and has set rates for the FITs depending on the project size and amount of electricity generated. With the exception of solar photovoltaic power, the rates are subject to an escalation percentage, which adjusts $20 \%$ of the contracted rate based on changes to the consumer price index. Table 1 shows the last FIT price schedule for all the renewable technologies (Mabee et al. 2011; OPA 2013d; OPA 2014a).

\section{Table 1 Ontario's Feed-in tariff schedule}

\begin{tabular}{l|c|c|c|}
\hline \multirow{2}{*}{ Renewable Fuel } & Project Size Tranche* & Price (c/kWh) & Escalation Percentage** \\
\hline \multirow{2}{*}{$\begin{array}{l}\text { Solar (PV) } \\
\text { (Rooftop) }\end{array}$} & $\leq 10 \mathrm{~kW}$ & 39.6 & $0 \%$ \\
\cline { 2 - 4 } & $>10 \mathrm{~kW} \leq 100 \mathrm{~kW}$ & 34.5 & $0 \%$ \\
\cline { 2 - 4 } $\begin{array}{l}\text { Solar (PV) } \\
\text { (Non-Rooftop) }\end{array}$ & $\leq 100 \mathrm{~kW} \leq 500 \mathrm{~kW}$ & 32.9 & $0 \%$ \\
\hline On-Shore Wind & $>10 \mathrm{~kW} \leq 500 \mathrm{~kW}$ & 29.1 & $0 \%$ \\
\hline Waterpower & $\leq 500 \mathrm{~kW}$ & 28.8 & $20 \%$ \\
\hline Renewable Biomass & $\leq 500 \mathrm{~kW}$ & 11.5 & $20 \%$ \\
\hline \multirow{2}{*}{ On-Farm Biogas } & $\leq 100 \mathrm{~kW}$ & 14.8 & $50 \%$ \\
\cline { 2 - 4 } & $>100 \mathrm{~kW} \leq 250 \mathrm{~kW}$ & 15.6 & $50 \%$ \\
\hline Biogas & $\leq 500 \mathrm{~kW}$ & 26.5 & $50 \%$ \\
\hline Landfill Gas & $\leq 500 \mathrm{~kW}$ & 21.0 & $50 \%$ \\
\hline
\end{tabular}

* The FIT Program is available to Small FIT Projects; that is, Projects generally $\leq 500 \mathrm{~kW}$.

** Escalation Percentage based on the Consumer Price Index will be applied to eligible Renewable Fuels as calculated in the FIT Contract. The Base Date is January 1 of the year in which the Project achieves Commercial Operation, unless the Project achieves Commercial Operation in October, November, or December, in which case the Base Date is January 1 of the following year.

FIT PRICE ADDERS

\begin{tabular}{l|c|c|c|c|c|c|}
\hline & \multicolumn{2}{|c|}{$\begin{array}{c}\text { Aboriginal Participation } \\
\text { Project }\end{array}$} & \multicolumn{2}{c|}{$\begin{array}{c}\text { Community Participation } \\
\text { Project }\end{array}$} & \multicolumn{2}{c|}{$\begin{array}{c}\text { Municipal or Public Sector } \\
\text { Entity Participation Project }\end{array}$} \\
\hline $\begin{array}{l}\text { Participation Level } \\
\text { (Equity) }\end{array}$ & $\mathbf{5 0 \%}$ & $\geq 15 \% \leq 50 \%$ & $>50 \%$ & $\geq 15 \% \leq 50 \%$ & $>50 \%$ & $\geq 15 \% \leq 50 \%$ \\
\hline $\begin{array}{l}\text { Price Adder } \\
\text { (c/kWh) }\end{array}$ & 1.5 & 0.75 & 1.0 & 0.5 & 1.0 & 0.5 \\
\hline
\end{tabular}

Note: The above table applies to all FIT Project sizes and all Renewable Fuels except Solar (PV) (Rooftop).

Source: OPA (2014a)

In 2011, the Ministry of Energy released a two-year review of Ontario's FIT program, which evaluated accomplishments such as creating thousands of direct and indirect clean energy jobs; contracting 4,600 megawatts $\left(\mathrm{MW}_{\mathrm{AC}}\right)$ in addition to 2,500 $\mathrm{MW}_{\mathrm{AC}}$ through the Green Energy Investment Agreement (GEIA)expected to produce enough electricity each year to power 1.8 million homes; 
attracting over $\$ 20$ billion, along with $\$ 7$ billion from the GEIA, in private-sector investment to Ontario during challenging economic times. This included a Korean consortium contracted by the Ministry to develop 1,369 $\mathrm{MW}_{\mathrm{AC}}$ of renewable energy generation to increase the amount of clean energy in Ontario's supply mix, to support Ontario's plan to replace coal-fired generation, and to contribute to lower greenhouse gas emissions and better health for Ontarians.

Moreover, the two-year review provides recommendations based on an international experience comparison such as reduction of FIT prices for solar and wind technologies, environmental administrative processes (Renewable Energy Approval regulation), and encouraging a Clean Energy Economic Development Strategy, focusing on Ontario-made renewable technology to be exported worldwide. Besides, the Office of the Auditor General of Ontario noted in its 2013 Annual Report, a follow-up of its 2011 annual report, recommendations related to the cost impact of renewable energy on consumers, development of an energy plan and renewable energy policy, procurement of renewable energy, reliability and delivery of renewable energy, and socio-economic, environmental and health impacts of renewable energy (Auditor General of Ontario 2013).

The Ministry of Energy released a directive on June 12, 2013 considering some FIT amendments: (i): OPA will be replacing the existing standard-offer FIT Program for large FIT projects (> $500 \mathrm{~kW}_{\mathrm{AC}}$ ) with a new competitive procurement process (engage with municipalities to identify locations and siting requirements), 
(ii) New small FIT and micro FIT offers to reach $1000 \mathrm{MW}_{\mathrm{AC}}$ during the period 2014 to 2018, (iii) Encourage citizen and community engagement and empower citizens and communities by prioritization of small FIT projects partnered or led by municipalities and public sector entities, incentives include: provision of a 'price adder' to the standard FIT pricing, provision of priority points during the application process, creation of capacity set-asides, and funding for project design and development.

Regarding the minimum required domestic content level (use of local resources and labour) the directive considered it to be in compliance with the World Trade Organization (WTO) rulings to keep going with development of Ontario's green energy technology, such as Ontario's PV manufacturing industry. Internationally, the domestic content requirements in Ontario brought harsh reactions. The EU, Japan, the US, and other countries challenged the Ontario policy through the WTO, arguing that renewable energy policies based on trade protectionism should not be tolerated (Stokes 2013).

OPA has issued several rounds of contract offers over the course of three versions of the FIT program, FIT 1.0 since March 2010 to July 2011 and FIT 2.0 on July 2013. For the current FIT 3.0 application window from November 4 to December 13,2013 , as of April $7^{\text {th }} 2014$, the OPA have received a total of 1,779 applications representing $436 \mathrm{MW}_{\mathrm{AC}}$. Of these, 1,398 applications- about 345 $\mathrm{MW}_{\mathrm{AC}}$-passed the completeness and eligibility reviews; then these applications 
have to pass the transmission and distribution availability testing in the order to be ranked according to the priority points awarded during the review process. More than $95 \%$ of applications are for solar photovoltaic projects and $73 \%$ represent rooftop solar projects. The OPA will award up to $123.5 \mathrm{MW}_{\mathrm{AC}}$ worth of contracts as a result of applications received during this application period and results will be announced in the second quarter of 2014 (OPA 2014b).

\subsubsection{Ontario's FIT solar PV program}

Originally the FIT solar PV program had two market segments, small rooftop commercial-scale and large ground-mounted utility scale, which were differentiated in prices based on type of installation and project size. After the review of the FIT program in 2012, each segment has a maximum project size of $500 \mathrm{~kW}_{\mathrm{AC}}$ (CanmetENERGY 2012).

As previously mentioned, the solar PV projects under the Ontario's FIT program are offered contracts of 20 years. The total FIT solar PV contracted capacity supply was $1,307 \mathrm{MW}_{\mathrm{AC}}$ only considering FIT 1.0 and FIT2.0 versions, meanwhile the FIT 3.0 capacity supply was $329 \mathrm{MW}_{\mathrm{AC}}$ for applications submitted and reviewed as of April $7^{\text {th }}, 2014$. Taking into account that FIT 3.0 has been over-subscribed, and the OPA's solar PV procurement target is approximately $117 \mathrm{MW}_{\mathrm{AC}}$ (95\% of the overall FIT 3.0 procurement target), the total FIT solar PV contracted capacity (shown in Figure 10) is 1,424 $\mathrm{MW}_{\mathrm{AC}}$ of which $82 \%$ corresponds to FIT 1.0 version. Regarding the FIT capacity supply by type of 
installations (market segment) (shown in Figure 11) the available data are based on solar PV contract offers during FIT 1 and FIT 2. It is important to note the relevant market share of ground-mounted PV installations (70\%) among FIT solar PV projects (OPA 2012; OPA 2014c).

Figure 10 Total FIT solar PV contracted capacity

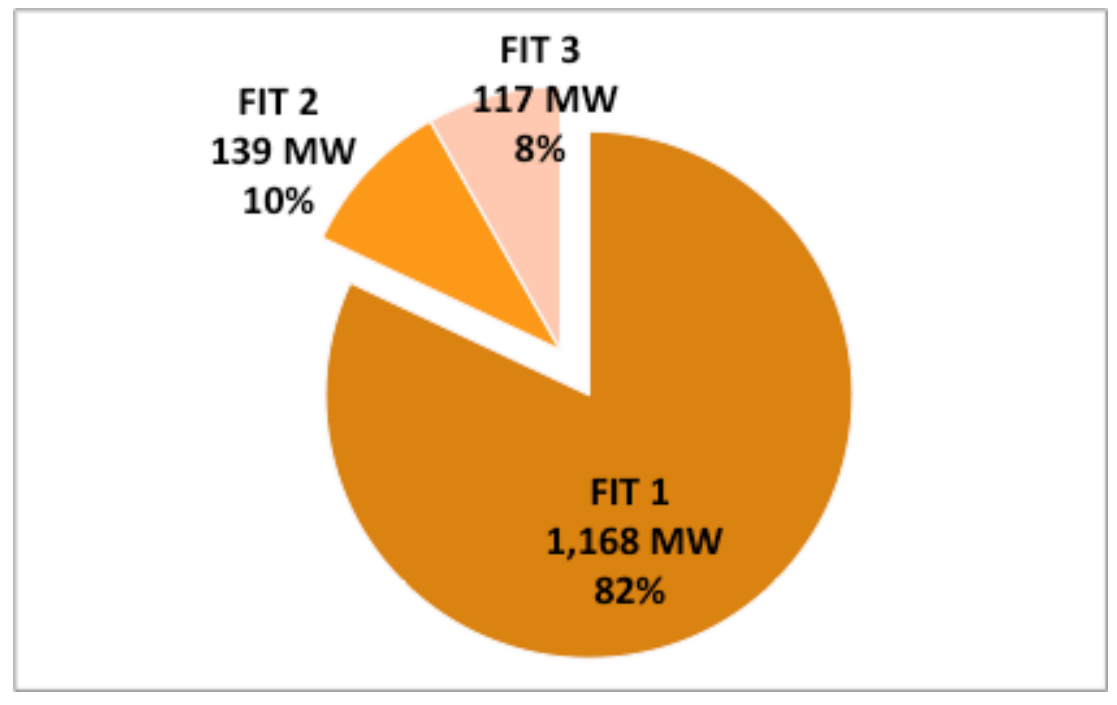

Source:

(1) OPA 2013b. FIT 1 and FIT 2. Including solar PV projects $>500 \mathrm{~kW}_{\mathrm{AC}}$

(2) OPA 2014b. Application contracts in process rated to FIT 3 procurement target as contract offers. Not including solar PV projects $>500 \mathrm{~kW}$ AC 
Figure 11 Total FIT solar PV contract offers by type of installation (FIT 1 and FIT 2)

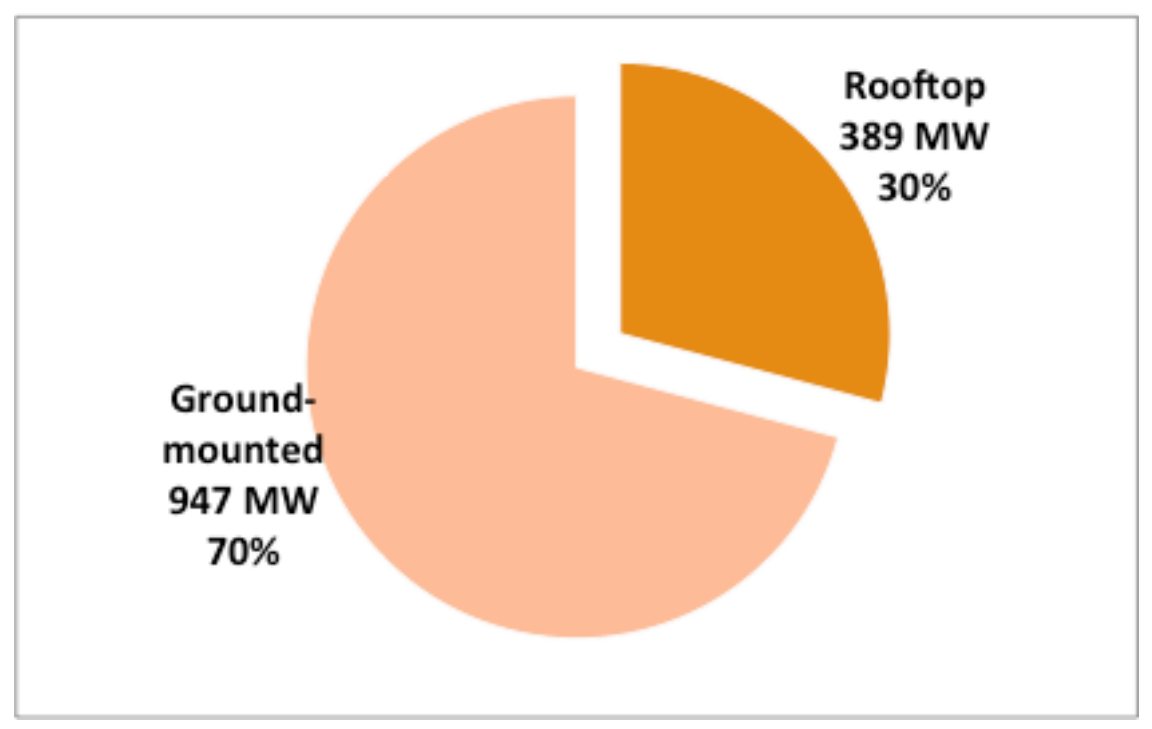

Source:

(1) OPA 2012. FIT 1.0 solar PV contract offers

(2) OPA 2014c. FIT 2.0 solar PV contract offers

Considering the market share of FIT solar PV ground-mounted contract offers related to FIT 1 and FIT 2, there is a concentration of FIT solar PV groundmounted contracts by the top contract holders. The seven largest contract holders and their partners have over $700 \mathrm{MW}_{\mathrm{AC}}$ under contract, representing approximately $80 \%$ of the total ground-mounted projects as show in Table 2 (CanmetENERGY 2012). 
Table 2 FIT solar PV ground-mounted contract holders

\begin{tabular}{|c|c|c|c|c|c|}
\hline $\begin{array}{l}\text { Solar } \\
\text { project } \\
\text { developer }\end{array}$ & $\begin{array}{l}\text { Contract } \\
\text { capacity } \\
\left(\mathrm{MW}_{\mathrm{AC}}\right)\end{array}$ & $\begin{array}{c}\text { Average } \\
\text { size } \\
\left(\mathrm{MW}_{\mathrm{AC}}\right)\end{array}$ & $\%$ & $\begin{array}{c}\text { Cumulative } \\
\%\end{array}$ & $\begin{array}{c}\text { Global } \\
\text { Headquarters }\end{array}$ \\
\hline $\begin{array}{l}\text { Recurrent } \\
\text { Energy }\end{array}$ & 170 & 6 & 18 & 18 & San Francisco, US \\
\hline Sky Power & 158 & 10 & 17 & 35 & Toronto, Canada \\
\hline $\begin{array}{l}\text { Northland } \\
\text { Power }\end{array}$ & 130 & 10 & 14 & 49 & Toronto, Canada \\
\hline SunEdison & 130 & 10 & 14 & 63 & $\begin{array}{l}\text { Maryland, US } \\
\text { (MEMC subsidiary) }\end{array}$ \\
\hline $\begin{array}{l}\text { Penn Energy } \\
\text { Renewables }\end{array}$ & 65 & 7 & 7 & 70 & $\begin{array}{l}\text { Pennsylvania, US } \\
\text { (Penn Real Estate } \\
\text { Group subsidiary) }\end{array}$ \\
\hline $\begin{array}{l}\text { Ontario Solar } \\
\text { PV Fields } \\
\text { (ATS\& Q- } \\
\text { Cell Joint } \\
\text { Venture) }\end{array}$ & 64 & 9 & 7 & 77 & $\begin{array}{l}\text { ATS: Cambridge, } \\
\text { Ontario, Canada } \\
\text { Q-Cell: Bitterfeld- } \\
\text { Wolfen, Germany }\end{array}$ \\
\hline $\begin{array}{l}\text { Canadian } \\
\text { Solar }\end{array}$ & 30 & 10 & 3 & 80 & Toronto, Canada \\
\hline Others & 200 & & & & \\
\hline Total & 947 & 9 & & & \\
\hline
\end{tabular}

Source: CanmetENERGY 2012 and companies webpages.

The FIT solar PV rates for rooftop and ground-mounted PV installations have decreased by close to $50 \%$ and $35 \%$ respectively over the period 2009 to 2014. Figures 12 - 13 show the evolution of the FIT price schedules for rooftop and ground-mounted, classified by size ranges (OPA 2013d; OPA 2014a). 
Figure 12 Evolution of FIT rooftop solar PV price schedules 2009-2014 (CADc/kWh)

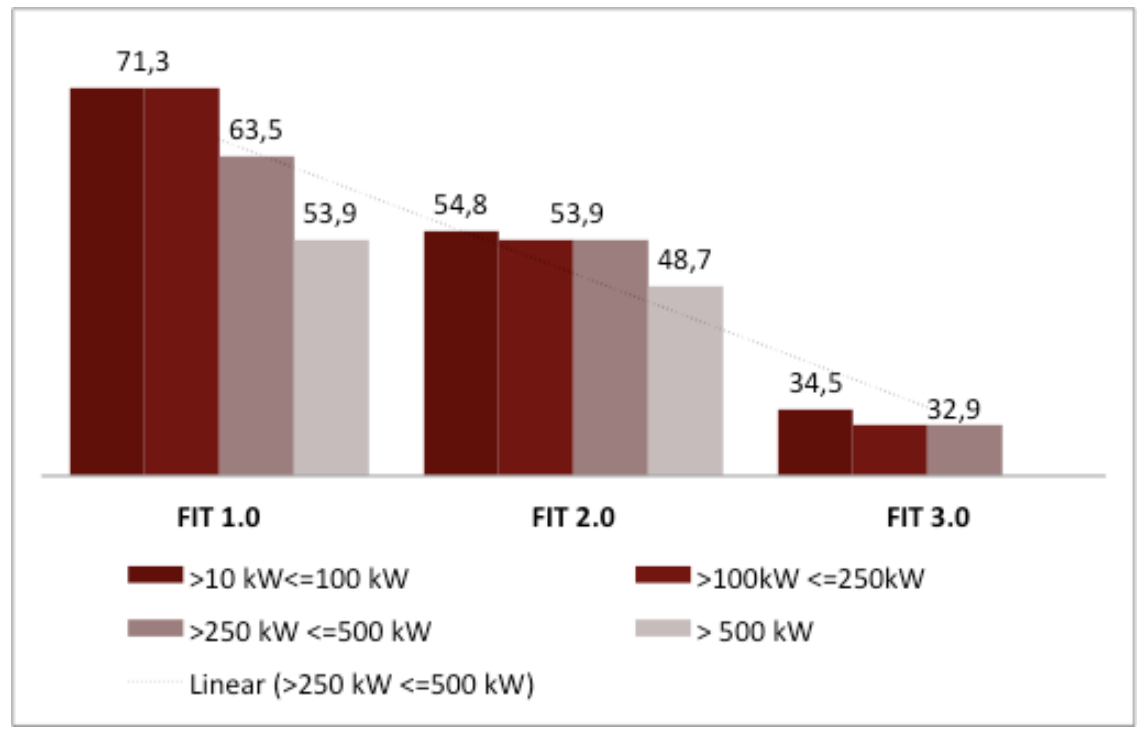

Source: OPA 2013d and OPA 2014a

Figure 13 Evolution of FIT ground-mounted solar PV price schedules 20092014 (CADc/kWh)

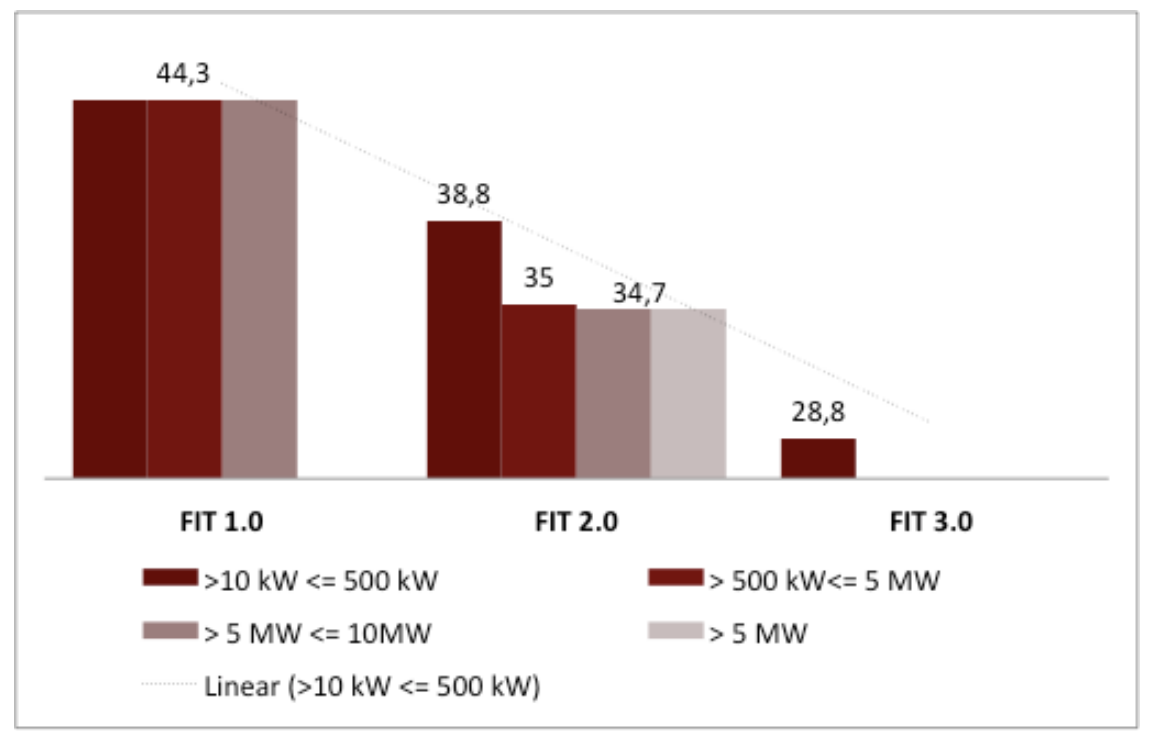

Source: OPA 2013d and OPA 2014a 


\subsubsection{Ontario's FIT challenges}

Important challenges lie ahead for the FIT program to face in order to increase the production of renewable power in Ontario. These include the development of accessible and cost-effective transmission and distribution, dropping solar technology costs, effective bundling of solar and wind power into dispatch, public support for a program that can have very significant rate impacts, and modification of the Ontario FIT mechanism through creating adequate generic incentives to promote the use of renewable sources or specific incentives according to the type of renewable technology (wind, solar or bio-energy) (Yatchew and Baziliauskas 2011; Moore et al. 2013). For instance, Moore et al. 2013 proposed a new approach of FIT rates and other related incentives to promote the biomass-to- electricity generation in Eastern Ontario. To overcome these challenges, an adaptive management of the FIT policy that considers the different stakeholder viewpoints could provide the necessary feedback and recommendations to support renewable energy strategies in Ontario (Stokes 2013).

\subsection{Comparative policy analysis and lesson drawing}

In the context of public policy, comparative policy analysis is an assessment of multinational experiences of a specific program to improve and influence the local policy (DeLeon and Resnick-Terry 1999). As a result of comparative policy analysis across different jurisdictions, policymakers can draw lessons, whether positive or negative, that is useful to learn what circumstances 
boost policy success or what mistakes could be avoided (Rose 2005; Illical and Harrison 2007). The general term "lesson drawing" means that "governments and non-governmental actors learning lessons, whether positive or negative, from their own policy history or that of other jurisdictions" (Illical and Harrison 2007 p327). Policy makers also set general criteria related to strengths and weaknesses that could be applied to evaluate an already in effect public policy (Rose 2005). A comparative policy analysis is oriented toward the evolution of policy outcomes (Lipp 2007).

Considering a jurisdiction's history and culture, the political environment and the existing institutional and socioeconomic similarities are important criteria when selecting adequate comparators (Knill 2005 p 771).

Previous studies regarding comparative policy analysis of FIT policy are focused on the evaluation of FIT policy effectiveness to achieve national objectives including energy security, industrial development, job creation, and reduction of $\mathrm{CO} 2$ emissions; and the lessons drawing from different jurisdictions. Laird and Stefes (2009) compared the different policy paths taken by Germany and the US related to the promotion of renewable energy, and established the drivers to implement FIT in Germany and the effectiveness of this policy regarding national objectives aforementioned. Lipp (2007) provides a policy comparison to promote renewable energy based on two main policies: FITs and the renewable portfolio standard in Denmark, Germany, and United Kingdom. 
Lesson drawing is obtained as well. Mabee et al. (2011) compared the similarities of FIT policies between Ontario and Germany. Yatchew and Baziliauskas (2011) compared FIT policies between Ontario, Germany, and Spain and drew lessons related to technology and pricing structure that may be applied to Ontario. Del Rio and Gual $(2007,2008)$ explained the main factors of the success of FIT in Spain and developed an integrated assessment of the FIT program. On the other hand, taking into account experiences from developing countries could bring a comprehensive evaluation. In this sense, Jacobs et al. (2012) developed a comparison of FIT programs in a Latin American region from an investment perspective.

\subsubsection{International feed-in tariff experiences}

FIT programs are the most widely adopted renewable energy policy at a national and state/provincial level. They have been implemented in at least 71 countries and 28 states/provinces around the world in 2013, especially in the European Union (EU) (REN21 2013). Mendonca et al. (2009, p.xxvii) laid out the success factors by which FIT programs can be measured based on international experience, such as, economic (creating a local manufacturing and export renewable industry and providing investor security); political (commitment to renewable energy deployment); social (empowering local citizens and communities); and environmental factors (reducing carbon emissions and dependence on fossil fuels). A well-designed FIT program can generate a successful renewable energy market and achieve multiple objectives such as 
energy security, $\mathrm{CO} 2$ reduction, creating jobs, and economic development. World leaders, based on their experience with the FIT mechanism during the last ten years, are Denmark, Germany and Spain. Under a comparative FIT policy analysis these countries can provide important lessons to other countries by examining the criteria to evaluate effectiveness for meeting national objectives, and by identifying additional factors that have influenced policy success (Lipp 2007; Cory 2009; Laird and Stefes 2009).

\subsubsection{German FIT a 'made in Germany' case}

In the early 90's German policymakers changed the direction of its energy policy to start the path of promotion, development and deployment of RET. This new policy direction was a result of the new European Union's energy policy on energy security issues and environmental problems with targets by 2020 of a $20 \%$ reduction in greenhouse gas emissions, improved energy efficiency of $20 \%$, and a $10 \%$ increase in the use of bio-fuel in transport fuel. The German national objectives to be aligned to European Union's goals were set up to promote renewable energy through incentives involving FIT programs, and to create employment through supporting the development of competitive green technology in the long-term; the results surpassed expectations. For instance, German's GHG emissions decreased 10.4\% between 1997 and 2007, and the electricity generation by renewables increased from $4.1 \%$ in 1997 to $15.1 \%$ in 2007 (Park and Eissel 2010). 
In 2000, the new government involved the Green party in the coalition and the Renewable Energy Sources Act (EEG) was released with the feed-in tariff as the main feature. Tariff differentiation depended on the type of technology, periodically revised rates for RE generators, and rates set to decrease over time to account for technology learning curves and 20-year long-term contracts (Lipp 2007).

Some measures helped to supplement FIT, which aimed to bring technologies up the learning curve. For instance, a significant increment of R\&D investment from 1990 to 1997 amounting to 2 billion euros, low-interest loan programs, planning privileges for wind projects, training programs, and expanded solar roof programs Lipp 2007). Subsequently, a degression rate was applied to achieve lower costs as production volumes increased and the technology improved. In the case of FIT rates for solar PV, these rates started with a comparably high value. However, the annual degression rate for solar PV is also much higher than that of other RETs (Park and Eissel 2010).

The main objective of the EEG was to double the share of renewables in the electricity market from 5 to $10 \%$ by 2010 using FIT programs and costs support for solar PV installation which could be as high as $5,000-8,000$ euros/ kW (Park and Eissel 2010). 
Nowadays, Germany is considered a world leader in solar electricity; the German market share in electricity generation capacity of solar energy has experienced a continuous growth since the 1990's. Solar PV generation capacity's average annual growth from 1990 to 2000 and from 2000 to 2012 reached $49.8 \%$ and $60.2 \%$, respectively, and power supplied by PV systems has soared from 60 Gwh in 2000 to 26,380 Gwh in 2012 (BMU 2013). According to the Fraunhofer Institute of Solar Energy Systems, Germany's accumulative solar energy generation capacity had reached around 37 GW as of April 2014, or about 21 percent of the country's total power generation capacity. In terms of electricity supply, solar PV represents only $18.5 \%$ of Germany's electricity production in 2012 avoiding 18.8 million tonnes of GHG emissions (13\% of GHG emissions avoided from all renewable energy sources) (Renewable Energy World Magazine May/June 2014; BMU 2013). Another driver to promote solar PV energy generation is the phase out of nuclear energy by 2022 as a consequence of the German government concerns regarding nuclear power safety following the Fukushima nuclear plant disaster in 2011 (BMU 2013).

Job creation in the solar PV sector has decreased from 110,000 people employed in 2011 to 50,000 to 60,000 in 2013 due to the economic crisis and the industrial policy in Asia with huge investments in PV production capacity (Fraunhofer 2014; Mundo-Hernandez et al. 2014). 
Despite this, 377,800 people were employed in the renewable energy sector in 2012 and approximately 1.5 million people are already working in this industrial sector, not only in manufacturing but also in training and education, and research and development represents a new source of income as well (Park and Eissel 2010; BMU 2013; Mundo-Hernandez et al. 2014).

The policy effectiveness levels for solar PV have been better than that of wind energy since 2008. For instance, the share of solar PV in electricity generation from renewable energy sources was just $5 \%$ in 2008 while the share of wind energy increased to $47 \%$ in the same year. However, the share of solar PV in electricity supply has reached $18.5 \%$ and the share of wind energy has decreased to 35.6\% (Park and Eissel 2010; and BMU 2013).

The German experience of a systematic expansion of renewable energy sources, especially solar PV, demonstrates that development and deployment of RETs are driving forces for environmental protection, sustainable economic growth, and the creation of secure future jobs through supportive government and local regulations (Park and Eissel 2010).

According to the update of the EEG in 2012, the challenge for renewable energy in Germany is an example of an economically successful and sustainable energy supply among industrialized countries. RETs will become one of the pillars of support for highly efficient German energy systems with the goal of 
reaching a share of electricity supply of at least of $35 \%$ by 2020 and $80 \%$ by 2050. Subsequently, GHG emissions will decrease $40 \%$ by 2020 (as compared to 1990) (BMU 2013).

\subsubsection{Spain}

Spain has been one of the most successful countries in the public promotion of electricity from renewable energy sources (RES), particularly electricity from wind. Together with Germany, the increase of RES generation in Spain is responsible for the significant rise in overall RES capacity in the EU in the last decade (Del Rio Gonzalez 2008). The National Renewable Energy Action Plan (2011-2020) of Spain, aligned with the EU Renewable Energy Directive 2009/28/CE, established as a target a renewable electricity production quota of $36 \%$ of total electricity generation in 2020 with a high share of $70 \%$ from wind and hydroelectricity technologies (PANER 2010; MINETUR 2012).

The RETs have an important role in the Spanish electricity generation industry with a market share of $29.7 \%$ in 2011 . However, solar PV only had a participation of $2.5 \%$ of total electricity production, meanwhile wind electricity represented 14.5\% (MINETUR 2012). In 2013, solar PV's installed capacity reached 4,641 MW and an electricity generation of 5,924 GWh (CNE 2013).

The Law 54/1997 opted for a FIT system, developed in RD2818/1998. This choice was probably influenced by policy developments elsewhere in 
Europe, by the relative absence of other alternatives, by the pressures of lobby groups, by the ease of implementation, and by the institutional inertia. Unemployment rates in Spain at the time were the highest of all OECD countries, and more than double the EU-15 average. This was a key issue in Spanish politics; thus, the government regarded RES-E deployment as a promising employment source (Del Rio Gonzalez 2008). FIT for solar power energy is fully guaranteed for the first 25 years of system operation and $80 \%$ thereafter. The Spanish feed-in tariff for applications of less than $100 \mathrm{kWh}$ was initially $€ 0.4404 / \mathrm{kWh}$ for the first 25 years of system operation and $€ 0.3523$ per kWh thereafter for systems installed until September 2008. Royal Decree RD1578/2008 regulated funding for the national solar PV program during 2010. The quarterly quota calls allocate awards and modify FIT rates according to fulfillment of quota. In February 2013, the annual feed-in tariff revision to the consumer price index was modified, resulting in a negative feed-in tariff movement (the price paid to the FIT participant was going down) (Solarbuzz 2014).

A key design choice made in RD2818 is the case of the "double option" (fixed premium or fixed tariff), which has been maintained in successive FIT reforms. The rationale of this unique feature of the Spanish system was to encourage the gradual participation of RES in the electricity market while simultaneously mitigating the risk for RES-E generators by ensuring a certain support level (Del Rio Gonzalez 2008). 
The Spanish FIT has its pros and its cons. Despite the existence of several barriers, the FIT has been highly successful in encouraging the promotion of wind but not so much concerning the other technologies. However, the environmental benefits from the system seem to outweigh its costs only in the case of two technologies (wind and small hydro) (Del Rio and Gual 2007).

Regarding solar PV, although the high potential and the increase in PV deployment during 2000 to 2007 were impressive, the low initial level of deployment and several barriers make its current contribution very low in spite of relatively high FITs. Major barriers were the high cost, poor credit conditions, bureaucratic delays related to the granting of investment subsidies, as well as a lack of inter-sectorial and inter-administrative coordination between PV manufacturers, the building sector and renewable producers (Del Rio and Gual 2007). In addition to wind, solar PV has recently experienced significant growth rates, although starting from a very low base in 2000 (Del Rio Gonzalez 2008).

\subsubsection{Denmark}

According to Lipp 2007, the Danish FIT program started in 1993, the same year as in Germany, but the changes of its energy policy began in the middle of the 1970 's to promote renewables. Systematically, the Danish government put measures in place to balance conventional and alternative energy, with a special focus on wind energy through the cooperative model. Public ownership was 
directly encouraged through a tax exemption for wind projects and later complimented with a FIT. The local ownership induced widespread support for renewables, especially wind, because benefits were distributed across a wide group of people; however, FIT was the central diffusor of wind projects through an investment subsidy of $30 \%$. Centers of research and R\&D activities were important factors of success in the development of wind power as well.

Some features of the Danish renewable energy policy are:

- RE target will be $100 \%$ of total supply electricity by 2050 (DEA 2014)

- Installed wind capacity was 4,193 MW in 2012 (DEA 2012)

- Renewable electricity produced in 2012 was 9,466TWh that represented a $43 \%$ of the total electricity supply with a wind energy share of $30 \%$ and solar power share of $0.3 \%$ (DEA 2012)

- $\mathrm{CO}_{2}$ emissions reductions of $31 \%$ in 2012 compared to 1990 (DEA 2012)

- Job creation in the wind sector represented 27,490 employees in 2013 (DWIA 2014)

\subsection{Assessment of effectiveness and sustainability for solar PV projects}

Maxim's study (2014) elaborated a comprehensive sustainability ranking of electricity generation technologies and solar PV technology was considered the fourth most sustainable technology after large hydroelectric projects followed by small hydro, and onshore wind. Table 3 shows the set of sustainability indicators used in Maxim's research. According to their definitions developed in the study, some of them should be used specifically to evaluate sustainability for 
solar- PV projects such as LCOE, efficiency, land use, environmental external costs, and job creation.

Table 3 Sustainability indicators for electricity generation technologies

\begin{tabular}{ll}
\hline Dimension & Indicator name \\
\hline Economic & Levelized cost of electricity (LCOE) \\
Technological & Ability to respond to demand \\
& $\begin{array}{l}\text { Efficiency } \\
\text { Capacity factor }\end{array}$ \\
Environmental & Land use \\
& External costs (environmental) \\
Socio-political & External costs (human health) \\
& Job creation \\
& Social acceptability \\
& External supply risk \\
\hline
\end{tabular}

Source: Maxim 2014

Evans et al. (2009) developed an assessment of renewable electricity generation technologies based on a ranking of a range of sustainability indicators such as price of generated electricity, greenhouse gas emissions generated during the full life cycle of the generation electricity unit, availability of renewable sources, efficiency of energy conversion, land requirements, water consumption, and social impacts. As a result of the evaluation wind power is the most sustainable followed by hydropower, photovoltaics, and then geothermal. 
Additionally, Fthenakis's research (2009) was oriented to evaluate the sustainability of photovoltaics and the case of thin-films cells. The study examined the potential of thin-films in a prospective life-cycle analysis, focusing on its affordability by decreasing direct costs, resource availability, and environmental impacts.

\subsection{Life Cycle Sustainability Assessment (LCSA)}

Given a system perspective on the evaluation of the three sustainability dimensions (economic, environmental, and social), the Life Cycle Sustainability Assessment (LCSA) framework was introduced and conceptualized by Kloepffer (2008) as a development of the life cycle assessment methodology integrated with sustainability assessment (Zamagni 2012). The LCSA is expressed in equations 1 to 3 :

LCSA $=$ Environmental LCA + Economic LCA + Social LCA Eq. 1

LCSA $=$ Life Cycle Assessment (LCA) + Life Cycle Costing (LCC) + Social Life Cycle Assessment (SLCA)

Eq.2

$\mathrm{LCSA}=\mathrm{LCA}+\mathrm{LCC}+\mathrm{SLCA} \quad$ Eq.3

LCSA of a product should be carried out by the independent application of three life cycle techniques assuming the same system boundaries and the same functional unit (Kloepffer 2008; and Valdivia et al. 2013). The implementation of LCSA helps value chain actors in evaluating which products are cost-efficient, environmentally friendly, and socially responsible (Valdivia et al. 2013). For 
instance, Traverso et al. (2012) combined the three methodologies to assess the sustainability performance through a comparison of LCSA results of photovoltaic modules in Germany and Italy.

\subsubsection{Life Cycle Assessment (LCA)}

The Life Cycle Assessment (LCA) is an internationally standardised and more suitable tool for evaluation of the potential environmental impacts of products or technology from cradle to grave (Fthenakis and Kim 2011; and Zamagni 2012). LCA technique assesses the aspects associated with the development process of a product and the potential impacts during the product's life, considering all the flows of pollutants, materials, and resources, and their impacts on human health, environment and resource depletion (Sherwani et al. 2014).

One of the applications of LCA is evaluating sustainability of energy generation technologies (Evans et al. 2009). In the case of clean energy technologies, such as solar PV generation electricity systems, where PV modules convert solar energy directly into electricity and generate environmental benefits such as decreases in GHG emissions and pollution, these systems do emit GHG emissions under an LCA approach.

Fthenakis and Kim (2011) performed a PV life cycle study and its environmental sustainability is evaluated through life-cycle energy and GHG 
emissions analysis. A conceptual description of the life cycle of PV systems starts from the upstream stage to the downstream stage in Figure 14. The upstream phase starts with the acquisition of raw materials, such as silica sand and iron ore; then energy is required to process them into other materials, such as crystalline silicon and steel and to manufacture the components for the solar module and the PV system as a whole. The building block of a solar PV system is a PV cell. A PV cell is a semiconductor device that converts solar energy into electricity. A module is a panel of electrically connected solar PV cells, and in addition to the cells, include the frame and glass. A solar PV array consists of several connected modules. The solar PV system consists of the array plus balance-of-system (BOS) components, which are needed to provide structural support and to deliver electricity to a facility or the grid. The BOS includes wiring, mounting hardware, and inverters. All components are then transported to the site and installed.

Prior to operation, most GHGs in the life cycle of solar PVs have been emitted. After the solar PV system has been installed, the operation life cycle phase includes minimal operating and maintenance activities such as module washing and replacement of inverters. The GHG emissions from this stage are small. After the PV system reaches the end of its life, the downstream life cycle stage includes system decommissioning, with parts disposed of or recycled (Fthenakis and Kim 2011; Hsu et al. 2012) 
Figure 14 Solar PV life cycle stages
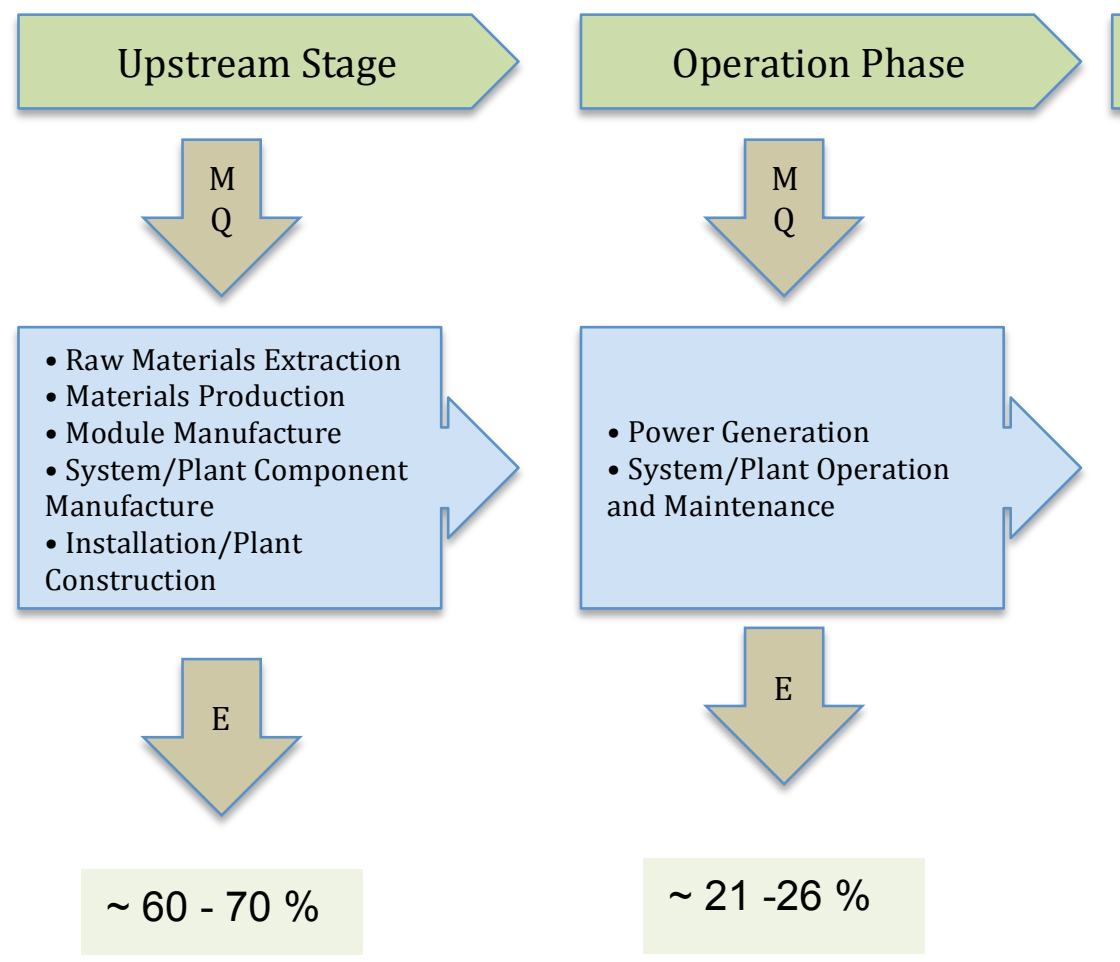

Downstream Stage

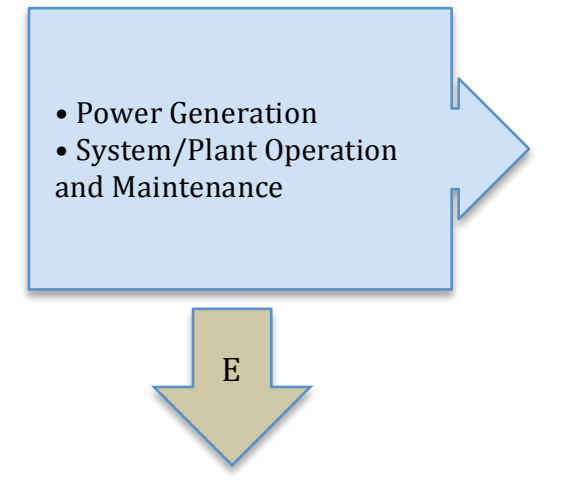

- System/Plant

Decommissioning

- Disposal

- Recycle

$\sim 5-20 \%$

\section{Life Cycle GHG emissions}

$M, Q$ : Material and energy inputs

E: Effluents (air, water, solids)

Source: Fthenakis and Kim 2011; and NREL 2012

Yue et al. 2014 described the crystalline silicon solar PV modules production in China as follows: starting with the mining of quartz sand, the silica in the quartz sand is then reacted in an electric arc furnace using carbon electrodes with wood, charcoal, and coal to produce "metallurgical grade" silicon (MG-Si, at least $98 \%$ purity). The MG-Si can be further purified into "electronic grade" (EG-Si, 9 N purity) or "solar grade" silicon (SoG-Si, $6 \mathrm{~N}$ purity) to meet the 
more stringent requirement in the electronics and solar industries. This is typically accomplished via either the "Siemens" process or the "modified Siemens" process. In the Siemens process trichlorosilane gas decomposes and deposits additional silicon onto silicon rods at $1100-1200{ }^{\circ} \mathrm{C}$, while in the modified Siemens process silane is used as feed gas instead and the decomposition temperature is kept at about $800{ }^{\circ} \mathrm{C}$. Manufacturing of mono-Si and multi-Si wafers involves the production of silicon ingots, followed by wafer sawing. On the other hand, ribbon-Si wafers are directly pulled or cast from liquid silicon. Subsequently, the cell manufacturing and module assembly processes are essentially identical for the three types of Si-PV technologies. Ethylene-vinyl acetate and glass sheets are used to encapsulate the PV modules and provide protection from the physical elements during operation. Aluminum frames are usually employed for additional strength and easy mounting.

Sherwani et al. (2014) have undertaken a comprehensive review of LCA for solar PV systems. Many of these studies have performed LCA of different types of solar PV systems depending on the material of the cells including the commonly used amorphous silicon, mono-crystalline silicon, and poly-crystalline silicon. LCA indicators were used as results such as energy payback time (EPBT) and GHG emissions. 


\subsubsection{Life Cycle Cost (LCC) and the Levelized Cost of Electricity (LCOE)}

The life cycle cost approach consists of an economic analysis using economic criteria proposed in the literature for the assessment of solar PV investments during all its life cycle, including pay back period, capital costs, return on investment, levelized cost of electricity and net present value (Rigter and Vidican 2010; Muneer et al. 2011).

The levelized cost of electricity (LCOE) is a life cycle cost concept which aims to account for all of the lifetime costs required to produce electricity output by an electricity facility. In other words, it is a minimum electricity price that a facility would have over the life of the project to cover all operating expenses, payment of debt, and the payment of an acceptable return to investors being compatible with net present value investors considerations (Reichelstein and Yorston 2013).

Generally, LCOE is the most popular metric to measure cost-effectiveness or evaluate the economic feasibility of an electricity generation project to make comparisons between electricity generation technologies. Also, LCOE is used to evaluate grid parities for emerging technologies (Branker et al. 2011; Darling et al. 2011; Hernandez-Moro and Martinez-Duart 2013). 


\section{CHAPTER III}

\section{RESEARCH QUESTIONS}

To achieve the purpose of this graduate research the following research questions were formulated based on the aforementioned literature review:

Question \# 1: As a policy instrument, how has Ontario's feed-in tariff program worked to promote solar - PV technology in Ontario?

According to the literature review about international FIT experiences, the policy implications of a FIT incentive mechanism are oriented towards four main goals: energy security, industrial development, job creation and reduction of $\mathrm{CO} 2$ emissions. A comparison of policy performance and lesson drawing from selected FIT jurisdictions and Ontario's FIT will provide an answer as to the level of success of Ontario's FIT in promoting solar PV technology in the province according to the aforementioned policy objectives.

Question \# 2: What criteria should be used to assess the effectiveness and sustainability of Ontario's FIT with a focus on solar PV, and what are the resulting costs/benefits to the province?

According to studies related to sustainability assessments of renewable energy technologies, there is an extensive body of literature about sustainability 
indicators that help policy decision makers examine the impact of RET on the environment and economy. However, it is important to know the specific, ideal sustainability indicators to evaluate solar PV in Ontario. Many studies evaluate the cost of solar PV, and other studies identify emissions and energy pay back of solar PV using life cycle assessment (Evans et al. 2009). Yet, there are no studies that perform an integrated evaluation of the value chain of the solar PV technology in Ontario using a set of sustainability indicators under the perspective of a life cycle assessment with an emphasis on social, economic and environmental impacts and an economic evaluation of the Ontario's solar PV supply-chain under a cost/benefit approach. 


\section{CHAPTER IV}

\section{RESEARCH METHODS}

In this research, as a first step, the Ontario feed-in tariff program was evaluated based on an extensive review of the literature concerning comparative policy analysis from global case studies to provide key features of FIT policy implementation to be compared with Ontario's FIT solar PV to obtain lessons and policy implications for the Province. Subsequently, a set of criteria was proposed for assessing the sustainability of Ontario's FIT for solar PV technology and for determining the costs/benefits to the province. Then a case study of Ontario's FIT solar PV value chain analysis was performed using the Life Cycle Sustainability Assessment (LCSA) framework with an economic and carbon footprint assessment based on the Levelized Cost of Electricity (LCOE), a Life Cycle Cost (LCC) concept, and the Life Cycle Assessment (LCA) methodologies respectively. Afterward both economic and environmental costs/benefits were determined under the cost/benefit approach. This method provided an analysis of the value chain of the Ontario's FIT solar PV and contributed to defining policy implications, including the effectiveness of regulatory incentives. The main steps in this research process are shown below in Figure 15: 
Figure 15 Research methods: main steps

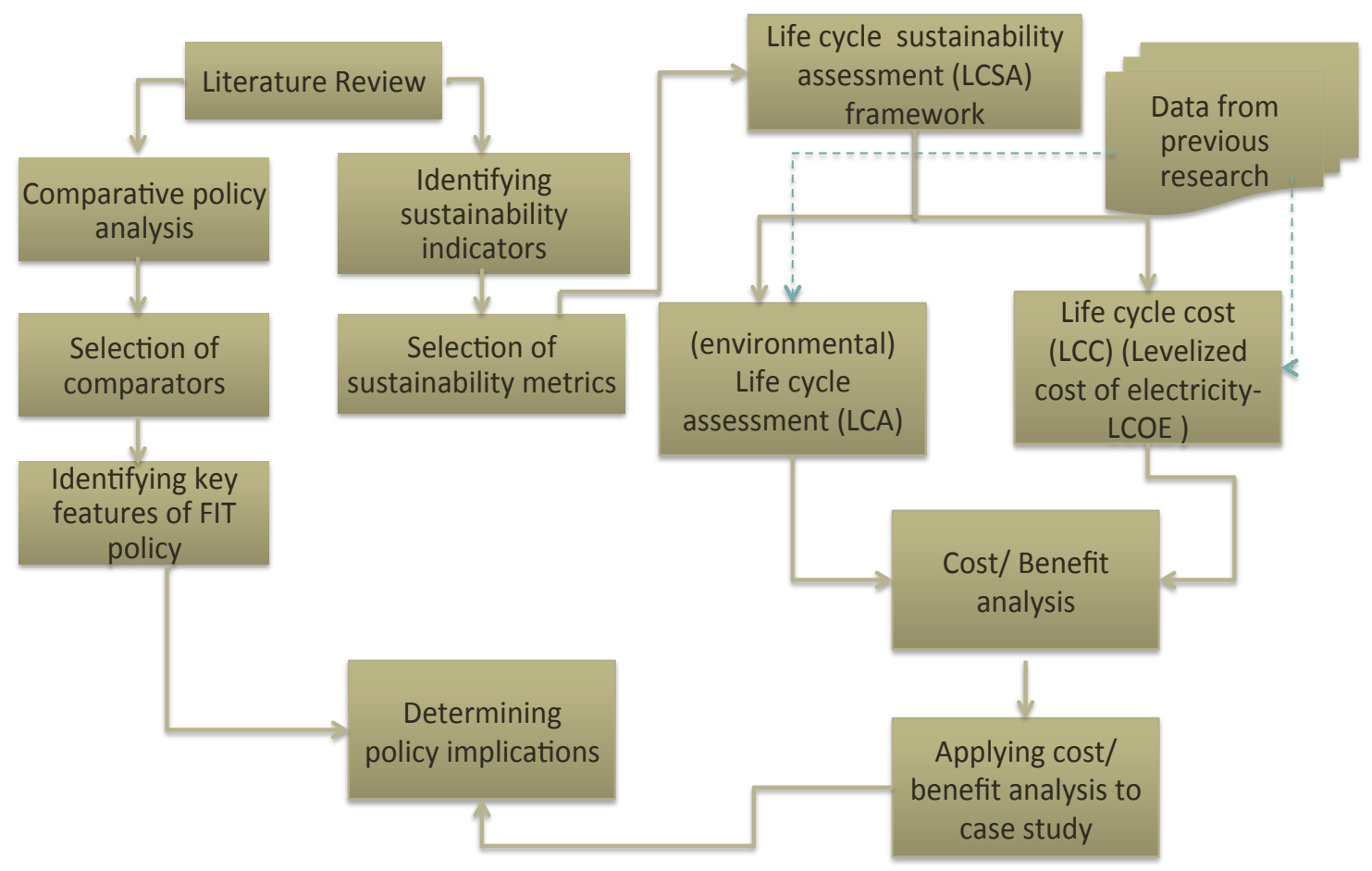

\subsection{Comparative policy analysis}

A literature review was performed to identify successful practices from feed-in tariff pioneers and successful regions/countries/jurisdictions on the design and implementation of feed-in tariff programs considering institutional and socioeconomic similarities such as Germany and Spain.

The rationale to compare FIT programs from Ontario, Germany, and Spain is that these jurisdictions have similar interests in economic growth and job creation (del Rio Gonzalez 2008; Mabee et al. 2011). Germany and Spain have become world leaders in solar PV power capacity because they were supported 
by long established renewable energy policies (Branker and Pearce, 2010; REN21 2013). Additionally, most of the renewable energy policies are compared through an economic and technical perspective; however, it is necessary to evaluate renewable energy policies under political considerations as well (Stokes 2013). This research study compared the Ontario FIT program with the FIT mechanisms in Germany and Spain because the German experience should provide important insights regarding economic and technical viewpoint and the Spanish FIT program is valuable under the social and political outlook.

Subsequently, this research study conducted a comparative policy analysis using a set of sustainability criteria to evaluate and analyze the effectiveness and sustainability of solar PV FIT policy frameworks in the selected jurisdictions. As a result of the comparative policy analysis, lessons and policy implications for Ontario are obtained.

\subsection{Sustainability criteria}

A set of sustainability indicators to evaluate sustainability for Ontario's FIT solar PV technology were selected from several sustainability indicators for power generation technologies, including traditional electricity generation technologies and renewable energy technologies. 
The selection process took into consideration two major premises. First, selection of the most relevant sustainability indicators related to solar PV technology performance, for instance ability to respond to demand and external fuel supply risk, are not relevant to solar PV technology. Second, each chosen sustainability indicator should provide a life cycle assessment approach because it is considered the most comprehensive evaluation approach to provide an understanding of what effects can a power generation technology have over its entire existence and to measure its compatibility with the sustainability development of the industry (Evans et al. 2009; Maxim, 2014). Moreover, the sustainability indicators were disaggregated according to the three traditional dimensions of sustainability: economic, environmental, and social. The selected sustainability indicators are shown in Table 4.

Table 4 Set of sustainability indicators for solar PV technology

\begin{tabular}{lll}
\hline Dimension & Indicator name & Units \\
\hline Economic & $\begin{array}{l}\text { Levelized cost of electricity } \\
\text { (LCOE) }\end{array}$ & CAD c/kWh \\
Environmental & $\begin{array}{l}\text { Life cycle GHG emissions } \\
\text { Job-years (Full-time employee }\end{array}$ & $\mathrm{tCO}_{2 \text { eq }} / \mathbf{k W h}$ \\
Social & FTE) & FTE $/ \mathbf{k W h}$ \\
\hline
\end{tabular}

Source: Evans et al. 2009 and Maxim 2014.

The economic dimension is represented by the levelized cost of electricity (LCOE), which is the average cost of generating electricity over the entire lifetime of the power unit. It accounts for all capital costs, operating and maintenance, 
fuel, decommissioning and even $\mathrm{CO}_{2}$ emission costs and government incentives. It is expressed in monetary units per unit of electricity generated (kWh). The environmental dimension accounts for the carbon footprint of the solar PV system, expressed in $\mathrm{tCO}_{2 \mathrm{eq}} / \mathrm{kwh}$, and is evaluated over its entire life cycle. The social dimension is represented by the job creation as a social factor of sustainable development and it is expressed as job-years (full-time employees per year involved during the implementation and operation of a power generation project) per kWh (Maxim 2014).

\subsection{Case study: Analysis of the value chain of Ontario's FIT solar PV system}

The second part of the assessment of the Ontario's FIT solar PV was to develop a case study of the analysis of its value chain. The value chain analysis was oriented to obtain a true economic value of the Ontario's FIT solar PV value chain and evaluate its contribution to sustainability development. The key features of the value chain analysis of a typical FIT solar PV system in Ontario are:

- The identification of the core activities along the chain, and their economic and environmental costs/benefits towards value creation.

- The assessment of the value chain's carbon emissions, from the upstream stage to the operational phase of the solar PV system via a life cycle assessment. 
Figure 16 shows a flow chart of the case study research methods. First, Ontario's FIT solar PV value chain was identified taken into account the public information available about the Ontario solar PV supply chain. Indeed, Porter's value chain model (1986) described the concept of "value chain system" between a firm and its supplier, which perform inter-related activities to achieve a sustainable competitive advantage and deliver maximum value to the end user for the least possible total cost (Walsh 2011). Then, the solar PV value chain in Ontario is used to determine the Ontario's solar PV system lifecycle and the system boundaries, which become input information in the LCSA framework.

Second, several assumptions are determined such as the typical weighted average capacity FIT solar PV program; average size by type of installation; typical type of PV module, orientation, location, and market segment; and annual PV potential and capacity factor by location. Based on these assumptions, three scenarios are determined to be the input parameters to the LCSA framework (LCOE and LCA).

Third, the LCSA framework comprises two methods: LCOE model and the environmental LCA. The LCOE model has taken into account the two main parameters of the total cost of the solar PV system, including the capital cost and the operating and maintenance (O\&M) cost, and the energy-generated output over its lifetime. The Net Present Value (NPV) of the cash flow and the electricity generated are calculated using a discount rate. The second method as part of 
the LCSA is the environmental LCA. Two metrics are determined: the LCA GHG emissions and the LCA GHG emissions avoided.

Fourth, a cost/benefit approach was used under a sustainability development perspective and going beyond the traditional economic definition to take account of socio-economic benefits to society. The economic margin is calculated from the LCOE results and the weighted average FIT solar PV rate. The net environmental benefit is calculated from the environmental LCA metrics.

Figure 16 Case study research methods: LCSA framework and cost/benefit approach

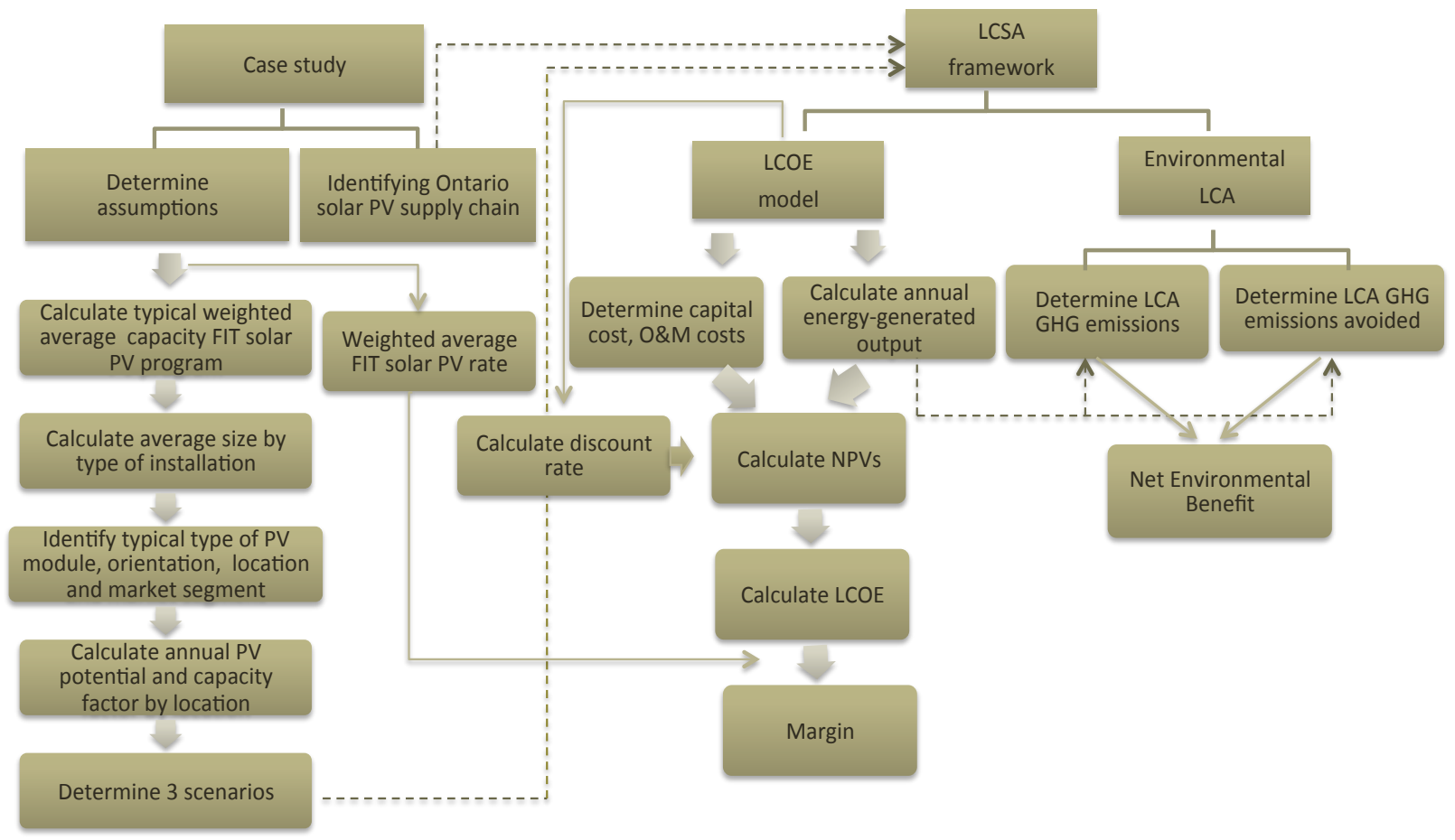




\subsubsection{Solar PV supply chain in Ontario}

CanmetENERGY's report (2012) presented an overview of the PV supply chain in Canada and noted that many of the supporting services are provided in Canada but only some of the manufactured components of the supply chain are made in Canada. Taking into account that the Ontarian solar PV market represented $91 \%$ of the Canadian solar PV market in 2011 (CanmetENERGY 2012), the Canadian PV supply chain is a close representation of a typical solar PV system supply chain in Ontario, which is shown in Figure 17.

The upstream stage basically comprises the module and balance of system (BOS) components manufacturing processes, followed by the downstream stage, which includes the EPC (Engineering, Procurement and Construction processes, operating and maintenance (O\&M) processes, and sales activities).

The module manufacturing process involves the following steps:

a. Silicon feedstock. Aforementioned, crystalline Silicon PV modules represented $90 \%$ of the Ontario's PV market and the first step to produce it is processing and refining polysilicon. Canada only has one company that produces polysilicon feedstock, Silicor Materials (American company located in Vaughan, Ontario), whose main client is Suntech (China) (Luukkonen et al. 2013). 
b. Ingots/Wafers. There are no silicon ingots/wafers manufacturers in Canada and these are acquired from foreign companies, especially from China, such as JA Solar, Motech and Gintech in China and Taiwan (CanmetENERGY 2012).

c. Cells. A similar situation occurs with silicon cells. They are purchased outside of Canada and are then electrically connected and laminated into modules.

d. Modules. The final assembly of the modules is done in Ontario to satisfy the domestic content requirements of the FIT program. This process starts when the cells are strung together (electrically), assembled on a back sheet, and encapsulated. Cover glass is applied before frames are attached, then an electrical testing is completed (CanmetENERGY 2012).

There are 11 Canadian PV module manufacturers, all of them located in Ontario. Together these 11 companies produced an estimated $460 \mathrm{MW}_{\mathrm{DC}}$ in 2012 , an increase of $142 \%$ from 2011 , and represented just under half of the total production capacity in the country (976 MWDC. Of these 11 manufacturers, 7 are Canadian companies. Among them, the largest company is Canadian Solar who achieves a vertical integration business model by developing its own projects in order to guarantee sufficient demand to justify the manufacturing investment. Indeed, amongst the largest FIT ground-mounted contract holders are three of the largest module suppliers, Canadian Solar, ATS, and SunEdison/MEMC. The main 
PV module manufacturers in Ontario are shown in Table 5 (CanmetENERGY 2012; and Luukkonen et al. 2013).

\section{Table 5 PV module manufacturers located in Ontario}

\begin{tabular}{|c|c|c|}
\hline $\begin{array}{l}\text { PV Module } \\
\text { Manufacturer }\end{array}$ & $\begin{array}{l}\text { Canadian / Global } \\
\text { Headquarters Location }\end{array}$ & Client /Developer \\
\hline \multirow[t]{2}{*}{$\begin{array}{l}\text { MEMC } \\
\text { /Flextronics } \\
\text { partnership }\end{array}$} & $\begin{array}{l}\text { MEMC: Belmont, } \\
\text { California }\end{array}$ & $\begin{array}{l}\left.\text { - Own projects worldwide (180 } \mathrm{MW}_{\mathrm{AC}}\right) \\
\left.\text { - Northland ( } 130 \mathrm{MW}_{\mathrm{AC}}\right) \text {. FIT ground- } \\
\text { mounted contract holder }\end{array}$ \\
\hline & $\begin{array}{l}\text { Flextronics: Toronto, } \\
\text { Canada }\end{array}$ & $\begin{array}{l}\left.\text {-SunEdison/MEMC (130 MW } \mathrm{MC}_{\mathrm{AC}}\right) \text {. FIT } \\
\text { ground-mounted contract holder }\end{array}$ \\
\hline Celestica & Toronto, Canada & $\begin{array}{l}\text { - Recurrent }\left(170 \mathrm{MW}_{\mathrm{AC}}\right) . \text { FIT ground- } \\
\text { mounted contract holder } \\
\text { - Soventix } \\
\text { - Opsun }\end{array}$ \\
\hline $\begin{array}{l}\text { Canadian } \\
\text { Solar }\end{array}$ & $\begin{array}{l}\text { Kitchener, Ontario, } \\
\text { Canada }\end{array}$ & $\begin{array}{l}\text { - Own projects worldwide (102 MW } \mathrm{MW}_{\mathrm{AC}} \text { ) } \\
\text { - Canadian Solar ( } 30 \mathrm{MW} \text { AC). FIT } \\
\text { ground-mounted contract } \\
\text { - Canadian Solar/partnerships ( } 47 \\
\text { MW } \\
\text { - SkyC). FIT ground-mounted contract } \\
\text { mounted contract holder }\end{array}$ \\
\hline ATS & $\begin{array}{l}\text { Cambridge, Ontario, } \\
\text { Canada }\end{array}$ & $\begin{array}{l}\text { - Own projects worldwide }\left(64 \mathrm{MW}_{\mathrm{AC}}\right) \\
\left.\text { - ATS (24 MW } \mathrm{MC}_{\mathrm{AC}}\right) \text { MicroFIT contract } \\
\text { - Hanwha }\left(160 \mathrm{MW}_{\mathrm{AC}}\right)\end{array}$ \\
\hline Eclipsall & Toronto, Canada & No data available \\
\hline
\end{tabular}

Source: CanmetENERGY 2012

The BOS manufacturing process considers the following components:

a. Inverters (central inverters, microinverter, DC/AC optimizers)

b. Racking/Mounting (ground mount, single-and-dual-axis trackers, commercial roof, residential) 
c. Wiring/Cabling (wire, combiner box)

Foreign companies mostly supply the BOS technology market in Canada with operations in Canada including Schneider-Electric (Xantrex), Eaton, and Sungrow Canada, or production through contract manufacturing with companies such as Celestica, SAE Power and Sanmina (Luukkonen et al. 2013).

The downstream stage comprises two processes. First, the EPC process, which includes (i) Engineering / design project (ii) identify and procure equipment required (iii) specify installation procedures (iv) sell product to end customer (v) guarantee product performance (vi) construct project (vii) interconnection / utility upgrades. Second, the O\&M process, which involves (i) monitor remotely (ii) inspect onsite (iii) maintain and clean (iv) maintain grounds, and (v) sell/provide spare parts.

The supporting activities are related to services and products needed to produce PV components and install projects. For instance, the manufacturing equipment refers to the capital equipment used to manufacture the solar equipment and the manufacturing material suppliers consider the raw materials consumed in the manufacturing process. Regarding the supporting services, financing also involves insurance products to insure against the guaranteed performance of a solar module. Consulting provides legal, engineering, business, and accounting advice to the PV supply chain (CanmetENERGY 2012). 


\section{Figure 17 Typical solar PV system supply chain in Ontario}

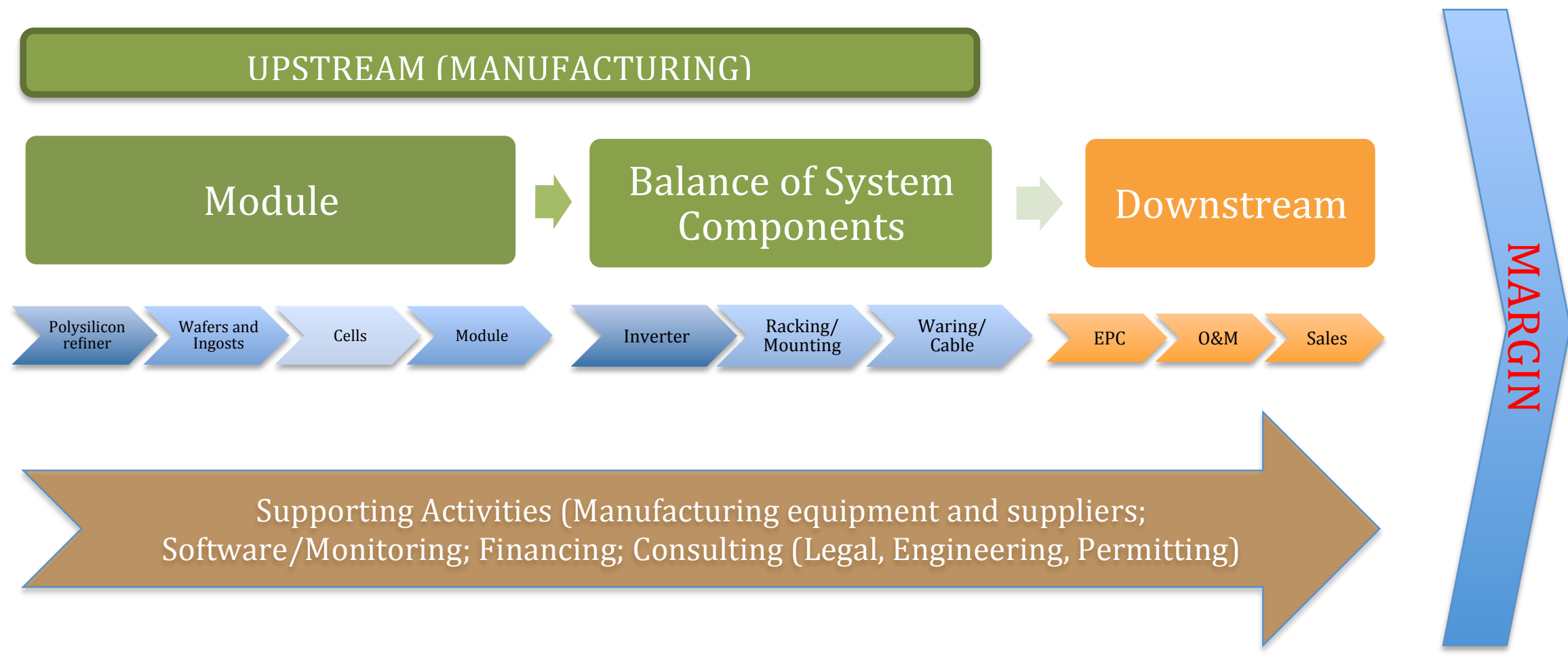

Source: CanmetENERGY 2012 


\subsubsection{Case study assumptions}

This research performed a case study related to an integrated value chain analysis of a typical Ontario's FIT solar PV system using the LCSA framework (LCA and LCC) to determine the costs/benefits for the Province of Ontario as a result of implementing the FIT program with focus on solar PV technology.

Since this research conducts a comparative analysis and looks at Ontario's overall FIT policy, this case study took as an analysis unit the average size of the overall FIT solar PV installations in Ontario. In this case study, the average nominal power capacity of the FIT solar PV system in Ontario is calculated through the weighted average of the overall FIT solar PV contracted capacity, taking into account all the executed contracts of solar PV electricity supply corresponding to the FIT 1.0 and FIT 2.0 versions from 2009-2012 and applications contracts related to the FIT 3.0 version in the application window from November to December 2013. This data is publicly available on the OPA website (OPA 2013b; OPA 2014b); the OPA information is provided as AC power output data.

As shown in Table 6, the weighted average size of a solar PV system in Ontario for the overall FIT program is $611 \mathrm{~kW}$ DC. Note that $71 \%$ of the total FIT solar PV capacity contracted was originated from the FIT 1.0 version that has influenced the overall result of the weighted average calculation. 
Table 6 Weighted Average FIT solar PV contracted capacity $\left(k_{\mathrm{AC}}\right)$

\begin{tabular}{|c|c|c|c|c|c|}
\hline Contract Type & $\begin{array}{l}\text { Total Number of } \\
\text { Executed } \\
\text { Contracts/Applications }\end{array}$ & Capacity $\left./ \mathrm{KW}_{\mathrm{AC}}\right)$ & $\begin{array}{c}\text { Mean Average Solar PV } \\
\left.\quad \text { Capacity } / \mathrm{KW}_{\mathrm{Ad}}\right)\end{array}$ & $\begin{array}{c}\text { Weights with respect } \\
\text { to capacity }\end{array}$ & $\begin{array}{l}\text { Weighted Average } \\
\text { Solar PV Capacity } \\
\qquad\left(\mathrm{kW}_{\mathrm{AC}}\right)\end{array}$ \\
\hline $\mathrm{FTT} 1^{1}$ & 1,520 & $1,168,000$ & 768 & 0.71 & 548.51 \\
\hline $\mathrm{FTT} 2^{1}$ & 914 & 139,000 & 152 & 0.08 & 12.92 \\
\hline$F \mid T 3^{2}$ & 1,339 & 329,270 & 246 & 0.20 & 49.48 \\
\hline Total FIT 2009-2013 & $\overline{3,773}$ & 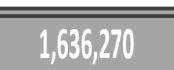 & $\overline{4344}$ & 1.00 & $\overline{6111}$ \\
\hline
\end{tabular}

Sources:

(1) OPA 2013b. Including solar PV projects $>500 \mathrm{~kW}_{\mathrm{AC}}$

(2) OPA 2014b. Application contracts in process not including solar PV projects $>500 \mathrm{~kW}_{\mathrm{AC}}$

In addition to the average size of the FIT solar PV system in Ontario, other basic PV system characteristics such as type of installation, market segment, and location were assumed as input parameters. These parameters influence the cost assumptions and the energy-generated calculation in this case study.

Since the Ontario's FIT solar PV program differentiated the rates by type of PV installation, rooftop and ground-mounted, the market share of each type of PV installation gives an indicator of the typical PV installation in Ontario. As previously mentioned, OPA provides statistical information about capacity contracts of FIT solar PV projects. In this sense, the rooftop and ground-mounted PV capacity statistical distribution is obtained through the OPA's contract offers database for the FIT 1 and 2 versions (Tables 7 and 8) (OPA 2014c) to prorate the summarized data in Table 6 into Tables 9 and 10. Considering that some proponents chose not to execute their contracts, the total number of contract 
offers and capacity is slightly different than the FIT executed contract data summarized in the Table 6.

Table 7 FIT 1.0 solar PV rooftop and ground-mounted contract offers

\begin{tabular}{|l|c|c|c|c|}
\hline Contract Type & $\begin{array}{c}\text { Total Number of } \\
\text { Contract Offers }\end{array}$ & $\%$ & Capacity $\left(\mathrm{kW}_{\text {Ac }}\right)$ & $\%$ \\
\hline Solar PV Rooftop & 1,442 & $91 \%$ & 257,000 & $22 \%$ \\
Solar PV Ground-mounted & 148 & $9 \%$ & 938,000 & $78 \%$ \\
\hline \hline Total FIT 1 2009-2011 & 1,590 & & $1,195,000$ & \\
\hline
\end{tabular}

Source: OPA 2012

Table 8 FIT 2.0 solar PV rooftop and ground-mounted contract offers

\begin{tabular}{|l|c|c|c|c|}
\hline Contract Type & $\begin{array}{c}\text { Total Number of } \\
\text { Contract Offers }\end{array}$ & $\%$ & Capacity (kW AC $)$ & $\%$ \\
\hline Solar PV Rooftop & 909 & $97 \%$ & 132,423 & $94 \%$ \\
Solar PV Ground-mounted & 25 & $3 \%$ & 8,600 & $6 \%$ \\
\hline \hline Total FIT 2 2012-2013 & 934 & 141,023 & \\
\hline
\end{tabular}

Source: OPA 2014c

Tables 9 and 10 show that ground-mounted PV installations in Ontario represented $62 \%$ of total $\mathrm{PV}$ installations and rooftop shared $38 \%$ of total $\mathrm{PV}$ market. For that reason, this case study assumed that a typical FIT solar PV system is a PV ground-mounted installation. 
Table 9 Weighted Average FIT solar PV rooftop contracted capacity (kW $\mathrm{AC}_{\text {) }}$ (prorated)

\begin{tabular}{|l|c|c|c|c|c|}
\hline Contract Type & $\begin{array}{c}\text { Total Number of } \\
\text { Contracts/Applications }\end{array}$ & Capacity $\left./ \mathrm{kW}_{\mathrm{AC}}\right)$ & $\begin{array}{c}\text { Mean Average Solar PV } \\
\left.\text { Capacity } / \mathrm{kW} \mathrm{Ad}_{\mathrm{Ad}}\right)\end{array}$ & $\begin{array}{c}\text { Weights with respect } \\
\text { to capacity }\end{array}$ & $\begin{array}{c}\text { Weighted Average } \\
\text { Solar PV Capacity } \\
\left(\mathrm{kW}_{\mathrm{Ad}}\right.\end{array}$ \\
\hline FIT1 & 1,379 & 251,193 & 182 & 0.40 & 73.59 \\
FIT2 & 890 & 130,523 & 147 & 0.21 & 30.79 \\
FIT3 & 1,126 & 240,290 & 213 & 0.39 & 82.44 \\
\hline \hline Iotal FIT 2009-2013 & 3,394 & 622,007 & 183 & 1 & 187 \\
\hline \hline
\end{tabular}

Table 10 Weighted Average FIT solar PV ground-mounted contracted capacity $\left(\mathrm{kW}_{\mathrm{AC}}\right)$ (prorated)

\begin{tabular}{|c|c|c|c|c|c|}
\hline Contract Type & $\begin{array}{c}\text { Total Number of } \\
\text { Contracts/Applications }\end{array}$ & Capacity $\left(\mathrm{kW}_{\mathrm{AC}}\right)$ & $\begin{array}{c}\text { Mean Average Solar PV } \\
\text { Capacity }\left(\mathrm{kW}_{\mathrm{AC}}\right)\end{array}$ & $\begin{array}{c}\text { Weights with respect } \\
\text { to capacity }\end{array}$ & $\begin{array}{l}\text { Weighted Average } \\
\text { Solar PV Capacity } \\
\quad\left(\mathrm{KW}_{\mathrm{AC}}\right)\end{array}$ \\
\hline FIT 1 & 141 & 916,807 & 6,480 & 0.90 & 5857.29 \\
\hline FIT 2 & 24 & 8,477 & 346 & 0.01 & 2.90 \\
\hline FIT 3 & 213 & 88,980 & 418 & 0.09 & 36.65 \\
\hline Total FIT 2009-2013 & 379 & $1,014,263$ & 2,677 & & 5,897 \\
\hline
\end{tabular}

Ontario's FIT solar PV market segments (in terms of scale of electricity generation) are categorized according to size of the PV installations independently of the type of installation. This case study took into account both commercial-scale (ranged from 0.1 to $1 \mathrm{MW}$ ) and utility-scale installations (usually defined as those larger than $1 \mathrm{MW}$ ) (Reichelstein and Yorston 2013). 
Concerning the location of a typical FIT solar PV system in Ontario, 90\% of total solar PV ground-mounted installations belong to the FIT 1.0 version (in Table 10). Then, Table 11 shows that $52 \%$ of total FIT 1.0 solar PV groundmounted PV installations with a capacity more than $500 \mathrm{~kW}$ AC were located in East Ontario. Likely, solar PV rooftop installations represented $94 \%$ of contract offers in FIT 2.0 version (Table 8 ) and $49 \%$ of these PV installations were located in Toronto, GTA (in Table 12). Besides, OPA has elaborated an electricity transmission availability map for the province of Ontario (see Appendix 1) (OPA 2013c). There are zones with transmission restrictions, among them Northwest Ontario, Sault, Bruce, and Niagara; but in the case of East Ontario and GTA the area availability is greater than $50 \mathrm{MW}$.

Table 11 FIT 1 solar PV ground-mounted contract offers by region (20092011) ${ }^{1}$

\begin{tabular}{|c|c|c|}
\hline$\left(>500 \mathrm{~kW}_{\mathrm{AC}}\right)$ & $\begin{array}{l}\text { Ground-mounted } \\
\text { capacity }\left(\mathrm{kW}_{\mathrm{AC}}\right)\end{array}$ & $\%$ \\
\hline \multicolumn{3}{|l|}{ Region $^{2}$} \\
\hline East & 480,166 & $52 \%$ \\
\hline Central & 227,750 & $25 \%$ \\
\hline Niagara & 46,500 & $5 \%$ \\
\hline Northwest & 40,000 & $4 \%$ \\
\hline Northeast & 78,750 & $9 \%$ \\
\hline West of London & 32,000 & $3 \%$ \\
\hline Sub-total $\left(>500 \mathrm{~kW}_{\mathrm{AC}}\right)$ & 905,166 & 99\% \\
\hline \multicolumn{3}{|l|}{$\left(<=500 \mathrm{~kW}_{\mathrm{AC}}\right)$} \\
\hline Sub-total (>500kW $\left.\mathrm{WC}_{\mathrm{AC}}\right)$ & 12,722 & $1 \%$ \\
\hline $\begin{array}{l}\text { Total FIT } 1.0 \text { solar PV ground- } \\
\text { mounted capacity contract } \\
\text { offers }\end{array}$ & 917,888 & $100 \%$ \\
\hline
\end{tabular}

Source:

(1) OPA 2014c (2) According OPA's transmission system availability map. OPA 2013c. 
Table 12 FIT 2 solar PV rooftop contract offers by region (2012 - 2013)

\begin{tabular}{|l|c|c|}
\hline \multicolumn{1}{|c|}{ Region $^{2}$} & Rooftop capacity $\left(\mathbf{k W}_{\text {AC }}\right)$ & $\%$ \\
\hline East & 10,304 & $8 \%$ \\
Bruce & 6,072 & $5 \%$ \\
GTA (Toronto) & 64,697 & $49 \%$ \\
central & 12,800 & $10 \%$ \\
Northeast & 1,226 & $1 \%$ \\
Southwest & 29,778 & $22 \%$ \\
West of London & 7,546 & $6 \%$ \\
\hline \hline Total FIT 2.0 solar PV rooftop & 132,423 & $100 \%$ \\
\hline Capacity contract offers & & \\
\hline
\end{tabular}

Source:

(1) OPA 2014c

(2) According OPA's transmission system availability map. OPA, 2013c

Furthermore, these locations validate the photovoltaic municipal ranking in terms of yearly PV potential (for South-facing PV panels with latitude tilt) elaborated for NRCan to select the major Canadian cities with high PV potential and Ontario corresponds with Ottawa and Toronto (NRCan nda). Das et al.`s (2012) research presented a planning optimization model for solar PV generation capacity in Ontario and concluded that the optimal siting of solar PV installations determined by the planning model, such as Ottawa and Toronto zones, was based on zonal supply demand forecast scenarios and inter-zonal transmission constraints.

As a result of the above information related to type of installation, market segment and location, the typical FIT solar PV system in Ontario $\left(611 \mathrm{KW}_{\mathrm{AC}}\right)$ is assumed that it is a ground-mounted, commercial-scale PV installation located in Ottawa. 
In addition to the value chain analysis of a typical FIT solar PV system in Ontario as a base case scenario, two additional scenarios were taken into account according to the type of solar PV installation: a utility-scale groundmounted PV system in Ottawa and a commercial-scale rooftop PV system in Toronto. The weighted average FIT ground-mounted solar PV capacity $(5,897$ $\mathrm{kW}_{\mathrm{AC}}$ ) and the weighted average FIT rooftop solar PV capacity (187 $\mathrm{kW}_{\mathrm{AC}}$ ) were the analysis units for these two scenarios. The rationale to consider two additional scenarios is based on the price, market share, and size differentiation between them. The main facts are described below:

a. According to all the price schedules of the FIT program from 2009-2013, there was a significant gap between rooftop and ground-mounted FIT rates of $14 \mathrm{CADc} / \mathrm{kWh}_{\mathrm{AC}}$ on average, being the lower gap of 4.1 CADc/kWhAC in FIT 3.0 and the higher one of 27 CADc/kWhAC in FIT 1.0 (OPA 2013d).

b. Solar PV ground-mounted capacity represents $62 \%$ of the total Ontario's FIT solar PV contracted capacity during $2009-20013$ and rooftop is $38 \%$ (Tables 9 and 10).

a. The weighted average FIT solar PV rooftop is $187 \mathrm{~kW}_{\mathrm{AC}}$ in contrast with the large weighted average of FIT solar PV ground-mounted that is 5,897 $\mathrm{kW}_{\mathrm{AC}}$ during the overall FIT program 2009-2013. Besides, FIT 1.0 groundmounted capacity was the $90 \%$ of the overall FIT solar PV groundmounted capacity (2009-2013) and 99\% of these type of projects had a size greater than $500 \mathrm{~kW}$ for each one (Tables 9,10 and 11; OPA, 2014c). 
Additionally, other technical assumptions used in the LCSA approach are calculated and explained below. Those parameters are the result of gathering data from government institutions such as the Ontario Power Authority and National Resources Canada (NRCan); industry associations such as the Canadian Solar Industries Association (CanSIA), journal papers, technical reports; and conference papers related to solar PV systems.

(i) Derate factor. This ratio represents the alternating current (AC) power output for each $\mathrm{kW}_{\mathrm{p}}$ of nominal direct current (DC) power the system is rated. The conversion from $D C$ to $A C$ requires inverters and transformers and comprises a loss of power, which accounts for the DC/AC ratio (Reichelstein and Yorston 2013). The Ontario Power Authority reports the installed power in $\mathrm{MW}_{\mathrm{AC}}$, therefore a derate factor of 0.83 (DC/AC ratio of 1.2) was used to convert between $D C$ and $A C$ power for this case study (CanmetENERGY 2012; Luukkonen et al. 2013).

(ii) Type of PV module. According to the literature review, the majority of PV modules installed in Ontario are multi-crystalline Silicon cellsbased PV technology (Luukkonen et al. 2013). Likewise, this case study assumed that multi-crystalline Silicon PV modules are used in each of Ontario's FIT solar PV system scenarios. 
(iii) PV Module efficiency (\%). It is the percentage of the solar energy converted to $\mathrm{DC}$ electricity by the module $\left(\mathrm{kWh} \mathrm{h}_{\mathrm{DC}} / \mathrm{kWh}\right)$. It depends on the type of PV module used, such as crystalline, thin-film or high concentrated (Hsu et al. 2012). The PV module efficiency is usually a specific parameter provided by the manufacturer and depends on the PV module's commercial model and project design. The multic-Si PV module efficiency will not be directly calculated (see Performance Ratio calculation below) for each scenario of the case study because the Ontario's FIT solar PV case study will not use specific project information; only typical average parameters for crystalline silicon solar PV systems in Ontario will be used. Therefore, this case study assumed a typical efficiency of crystalline silicon PV commercial modules ranging from 13\%-20\% during the period 2008 - 2013 (IEA 2011 p119).

(iv) PV array orientation. The majority of solar PV installations in Ontario have a sun-tracking orientation as fixed-South facing orientation at tilt latitude (CanmetENERGY 2012). Additionally, the lower cost of PV electricity is obtained with optimally-inclined fixed PV modules (Hernandez-Moro and Martinez-Duart 2013). Such is the case of Ontarian ground-mounted and rooftop projects without tracking systems, the lower upfront cost offsets the lower revenue (as a result of lower energy), but still permits a reasonable rate of return on equity 
(OPA 2010a). Therefore, each scenario of the Ontario's FIT solar PV system case study assumed a fixed-South facing orientation at tilt latitude.

(v) Grid connection. The grid-connected market in Ontario reached $100 \%$ in 2012. It is assumed a grid-connected distributed (embedded) PV power system configuration is used for a commercial scale and a grid-connected centralized PV power system for a utility-scale (Luukkonen et al. 2013).

(vi) Solar Irradiation. It is the average energy flux from the sun (Hsu et al. 2012). It is also called solar resource or global insolation and represents the average annual energy per unit area $\left(\mathrm{kWh} / \mathrm{m}^{2}\right)$ reaching the location where the systems are installed (Hernandez-Moro and Martinez-Duart 2013). Global solar irradiation is good to excellent in zones between $45^{\circ}$ South and $45^{\circ}$ North, including the Middle East, US, Africa, most of Latin America, Australia, most of India and parts of China (IEA 2011). The NRCan web site provides a PV map of a solar resource in any location of Canada and a database of solar resources for Canadian municipalities (see Appendix 2)(NRCan ndb). The maps give estimates of the mean daily global insolation (in $\mathrm{MJ} / \mathrm{m}^{2}$ and in $\left.\mathrm{kWh} / \mathrm{m}^{2}\right)$. They are presented for each month and for the entire year for six different PV array orientations: a sun-tracking orientation and five 
fixed South-facing orientations with latitude, vertical $\left(90^{\circ}\right)$, horizontal $\left(0^{\circ}\right)$ and latitude $\pm 15^{\circ}$ tilts. In the case of the province of Ontario the yearly mean daily global isolation estimates are in the range of 3.3 to 5 $\mathrm{kWh} / \mathrm{m}^{2}$, South-facing, tilt=latitude, and these values should be multiplied by 365 days/year to obtain an annual mean global insolation $1,204-1,825 \mathrm{kWh} / \mathrm{m}^{2} / \mathrm{yr}$. In the case of Ottawa and Toronto the yearly mean daily global isolation from the NRCan database are $4.4 \mathrm{kWh} / \mathrm{m}^{2}$ and $4.3 \mathrm{kWh} / \mathrm{m}^{2}$, respectively.

(vii) Performance ratio (PR). The overall PV system losses are quantified by the performance ratio and depend on the type of the module's performance (i.e. losses on a PV array's power output that depending on cell temperature), on PV system's performance under certain operating conditions (solar irradiation, angle of incidence, and temperature), and PV system design. PR is a measure of a PV actual system yield $\left(\mathrm{kWh}_{\mathrm{AC}} / \mathrm{kW}_{\mathrm{DC}}\right)$ to the nominal yield, which is numerically equal to the insolation in the plane of the $\mathrm{PV}$ array in $\mathrm{kW} \mathrm{DC} / \mathrm{m}^{2}$. Consequently, PR is expressed as $\mathrm{m}^{2} / \mathrm{kW}_{\mathrm{DC}}$ (McKenney 2008; Hsu et al. 2012; Hernandez-Moro and Martinez-Duart 2013).

Likewise, PR is expressed as the ratio of the PV system's annual electric generation output after accounting for system losses compared to its nameplate rated capacity $\left(\mathrm{kW}_{\mathrm{DC}}\right)$, and taking into account the 
module efficiency and the solar irradiation at the system's location (NREL nda). System efficiency can be obtained by multiplying the PV module efficiency by the performance ratio as is expressed in equation 4.

Performance Ratio $=$ Annual Energy $(\mathrm{kWh}) /($ Input Irradiation $(\mathrm{kWh}) \times$ Module Efficiency (\%)) Eq.4

Where Input solar irradiation $(\mathrm{kWh})$ is the product of the total radiation incident on the array and the total area of modules.

According to Canadian studies a 0.75 PR is a realistic assumption in Canada with yearly average performance ratios in the $0.7-0.75$ range reached by systems with latitudes of $44^{0}$ North up to $64^{0}$ North, which is the case of Ottawa $(-75.70 \mathrm{E}, 45.42 \mathrm{~N})$ and Toronto $(-79.39 \mathrm{E}, 43.65 \mathrm{~N})$ (McKenney et al. 2008).

(viii) Photovoltaic (PV) electricity generation potential (Annual PV potential). It is calculated by McKenney et al. (2008) as the electricity generation per nominal power (in $\mathrm{kWh}_{\mathrm{AC}} / \mathrm{kW}_{\mathrm{DC}}$ ) using the equation 5 :

$$
\frac{E}{P}=P R^{*} H N=0.75 H N \quad \text { Eq. } 5
$$

Where, $\mathrm{E}=$ Annual electricity generated in $\mathrm{kWh}$ 
$\mathrm{P}=$ Nominal capacity $(\mathrm{kW} \mathrm{DC})$

$\mathrm{PR}=$ Performance ration in $\mathrm{m}^{2} / \mathrm{kW}_{\mathrm{DC}}$

$\mathrm{HN}=$ Annual global insolation $\left(\mathrm{kWh} / \mathrm{m}^{2} /\right.$ year $) . \mathrm{H}$ is the yearly mean daily global insolation $\left(\mathrm{kWh} / \mathrm{m}^{2}\right)$ and $\mathrm{N}$ is 365 days/year.

The NRCan website provides a PV map of PV potential for Canada and a database of photovoltaic (PV) potential for Canadian municipalities as well (NRCan ndb). The maps provide estimates of the electricity that can be generated by grid-connected photovoltaic arrays without batteries (in $\mathrm{kWh}_{\mathrm{AC}} / \mathrm{kW}_{\mathrm{DC}}$ ) (McKenney et al. 2008). For the province of Ontario the annual PV electricity generation potential estimates are in the range of 1,100 to $1,400 \mathrm{kWh} \mathrm{h}_{\mathrm{AC}} / \mathrm{kW}$, Southfacing, tilt=latitude and for the Ontarian municipalities of Ottawa and Toronto the PV electricity generation potential estimates from the NRCan database are 1,198 $\mathrm{kWh}_{\mathrm{AC}} / \mathrm{kW}_{\mathrm{DC}}$ and 1,161 $\mathrm{kWh} \mathrm{h}_{\mathrm{AC}} / \mathrm{kW}_{\mathrm{DC}}$ South-facing, tilt=latitude, respectively. These values can be validated using equation 5 and an approximated performance ratio of 0.746 and 0.74 is obtained for Ottawa and Toronto, correspondingly.

(ix) Capacity Factor (\%). It is the ratio of the PV system's predicted electrical output in the first year of operation to the rated power output, which is equivalent to the quantity of electricity the system would generate if it operated at its nominal capacity for every hour of the 
year. For PV systems, the capacity factor is an AC-to-DC value (NREL $n d b)$.

$$
\begin{aligned}
& \text { Capacity Factor = Net Annual Energy }(\mathrm{kWh} A C / \text { year }) / \text { System Capacity } \\
& \begin{array}{cc}
\left(\mathrm{k} W_{D C}\right) / 8760(\mathrm{~h} / \mathrm{yr}) & \text { Eq. } 6 \\
=\text { Annual PV potential }\left(k W h_{A C} /\left(k W_{D C}\right) / 8760(\mathrm{~h} / \mathrm{yr})\right. & \text { Eq. } 7
\end{array}
\end{aligned}
$$

In Ontario, the capacity factor varies regionally and depends on solar irradiation. In the case of the solar PV systems located in Ottawa and Toronto, the capacity factor for the first year of operation resulted from equation 7 and their corresponding annual PV potentials are $13.7 \%$ and $13.3 \%$, respectively. These values are similar to the $13 \%$ capacity factor used for OPA in the calculation of FIT rate of return, considering OPA's capacity factor is an average of the expected capacity factor of the system over 20-year life, and taking into account an expected PV module's degradation rate (OPA 2010a).

(x) Project lifetime. For each scenario of the Ontario's FIT solar PV system case study, the guaranteed period of 20 years (FIT contract term with OPA) as a project lifetime is assumed, instead of the average working life of the PV system (OPA 2010b). The average working life is defined as the system lifetime expressed in years that a PV system operates, with routine maintenance and repairs, before severe 
degradation in its ability to produce electricity (Hsu et al. 2012). Crystalline-Si PV modules, the key component of c-Si PV systems, are warranted for a lifetime between $25-30$ years by most manufacturers (Branker et al. 2011; Hsu et al. 2012; and Hernandez-Moro and Martinez-Duart, 2013).

Table 13 shows a summary of the technical assumptions used in each Ontario's FIT solar PV system case study's scenario.

Table 13 Summary of the assumptions of the Ontario's FIT solar PV system case study

\begin{tabular}{|c|c|}
\hline Parameters & Values \\
\hline $\begin{array}{l}\text { Nominal power capacity and } \\
\text { market segment }\end{array}$ & $\begin{array}{l}\text { Scenario 1: } 611 \mathrm{~kW} \text { DC (commercial-scale) } \\
\text { Scenario 2: } 187 \mathrm{~kW}_{\mathrm{DC}} \text { (commercial scale) } \\
\text { Scenario 3: 5,897 kW } \mathrm{kC}_{\mathrm{DC}} \text { (utility-scale) }\end{array}$ \\
\hline Derate factor & $\mathrm{AC} / \mathrm{DC}=0.83 ; \mathrm{DC} / \mathrm{AC}=1.2$ \\
\hline Type of PV module & Multi-crystalline Silicon (multi-c Si) \\
\hline PV module efficiency & $13 \%-20 \%$ \\
\hline Type of installation and location & $\begin{array}{l}\text { Scenarios } 1 \text { and 3: Ground-mounted in } \\
\text { Ottawa } \\
\text { Scenario 2: Rooftop in Toronto (GTA) }\end{array}$ \\
\hline PV array orientation & $\begin{array}{l}\text { Fixed-South facing orientation at tilt } \\
\text { latitude }\end{array}$ \\
\hline
\end{tabular}




\begin{tabular}{ll}
\hline Grid connection & $\begin{array}{l}\text { Scenario } 1 \text { and 2: Grid-connected } \\
\text { distributed } \\
\text { Scenario } 3: \text { Centralized grid-connected }\end{array}$ \\
Solar Irradiation & Ottawa: $4.4 \mathrm{kWh} / \mathrm{m}^{2}$ \\
& Toronto: $4.3 \mathrm{kWh} / \mathrm{m}^{2}$ \\
Performance Ratio & $0.7-0.75$ \\
Annual PV potential & Ottawa: $1,198 \mathrm{kWh} / \mathrm{kW}_{\mathrm{DC}}$ \\
& Toronto $(\mathrm{GTA}): 1,161 \mathrm{kWh} / \mathrm{kW}$ \\
Capacity factor & Ottawa: $13.7 \%$ \\
Project lifetime & Toronto: $13.3 \%$ \\
\hline
\end{tabular}

In summary, this case study comprises three scenarios that represent the typical solar PV system characteristics in Ontario such as multi-crystalline Silicon cell based PV modules and fixed-South facing orientation at tilt latitude, but differentiated by size, type of installation, market segment and location as follows:

- Scenario 1 (base scenario): $611 \mathrm{~kW}$, ground-mounted, commercialscale in Ottawa

- Scenario 2: $187 \mathrm{~kW}$ DC, rooftop, commercial-scale in Toronto

- Scenario 3: 5,897 kW 


\subsubsection{LCSA framework}

The value chain of the FIT solar PV system in Ontario is evaluated under the LCSA framework considering these criteria:

a) Functional Unit: Multi-crystalline Silicon solar PV system.

b) System boundaries. The system boundaries used for the scope of the (environmental) LCA and the LCC include the upstream phase, which comprises raw material acquisition and processing (multi-crystalline $\mathrm{Si}$ feedstock), manufacturing (ingots/wafers, cells, modules and BOS) and the operation phase of the solar PV system life cycle. The decommissioning, recycling, and disposal phases are not part of our system boundaries because of limited published studies in these areas of a solar PV life cycle. Since a life cycle, by definition, considers several phases of a product's life from manufacture to end of life, solar PV LCAs do not need to focus on all life cycle stages because the GHG emissions of solar PVs are heavily weighted toward upstream processes, such as material production and component manufacturing (Hsu et al. 2012).

c) Allocation. Province of Ontario (Toronto and Ottawa cities).

Data to be collected and processed is obtained from secondary research (studies, government reports, business organizations reports). In (environmental) LCA indicators and LCC analysis, results are represented by quantitative data to explain the benefits of the solar PV implementation in Ontario. 
Meanwhile, Social Life Cycle Assessment (S-LCA) metrics are not taken into account in this case study because of the lack of validated information related to social impacts (job creation) in Ontario associated with the development of a solar PV industry.

\subsubsection{1 (Environmental) LCA approach}

The literature review noted LCA methodology in general performs two main analyses on a product, process or service;the life cycle energy and GHG emissions assessments. In this research, the environmental LCA metric used is the life cycle GHG emissions, calculated in terms of $\mathrm{gCO}_{2 \mathrm{eq}} / \mathrm{kWh}$ AC. This metric was applied to the upstream and operation life cycle stages of a typical Ontario solar PV system. Instead of the GHG emissions calculation related to the operational phase, which are minimal (Hsu, et al. 2012), this study estimated the GHG emissions avoided as a result of the installation and operation of a solar PV system and the corresponding displaced production from a natural gas generation unit in the Ontario electricity grid.

Most of the upstream processes of a typical Ontario PV system life cycle are done outside Canada. Multi-c based ingots/wafers and cells do not come from Ontario because no manufacturers and commercial-scale suppliers exist and they are purchased from outside Canada, mainly from China. The PV modules are assembled in Ontario in order to comply with the FIT domestic content requirements (CanmetENERGY 2012 p40). However, all of the several 
studies of life cycle GHG emissions of c-Si PV systems, mainly limited to Europe and US, and the few LCA studies of C-Si PV modules manufactured in China, showed high variability in results and inconsistencies with methodologies, boundaries, and assumptions. For instance, Sharwani et al. (2010) reviewed life cycle GHG emission studies of multi-c Si solar PV systems (including modules and BOS) in regions such as China (9.4-16.5 $\left.\mathrm{gCO}_{2 \mathrm{eq}} / \mathrm{kWh}_{\mathrm{AC}}\right)$, the US (72.4 $\mathrm{gCO}_{2 \mathrm{eq}} / \mathrm{kWh}_{\mathrm{AC}}$ ), and Europe $\left(54.6 \mathrm{gCO}_{2 \mathrm{eq}} / \mathrm{kWh}_{\mathrm{AC}}\right)$. Fthenakis and $\mathrm{Kim} 2011$ reported a life cycle $\mathrm{GHG}$ emissions estimate of $38 \mathrm{~g} \mathrm{CO}_{2 \mathrm{eq}} / \mathrm{kWh}_{\mathrm{AC}}$ (boundary system limited to the upstream stage), for a multi-c Si rooftop PV system under Southern European conditions: insolation of $1,700 \mathrm{KWh} \mathrm{h}_{\mathrm{Ad}} / \mathrm{m}^{2} / \mathrm{yr}$, and performance ratio of 0.75 . Recently, Yue et al. 2014 compared the carbon footprint of multi-c Si PV modules manufacturing between China $\left(69.2 \mathrm{gCO}_{2 \mathrm{eq}} /\right.$ $\left.\mathrm{kWh}_{\mathrm{AC}}\right)$ and Europe $\left(31.8 \mathrm{gCO}_{2 \mathrm{eq}} / \mathrm{kWh}_{\mathrm{AC}}\right)$.

As a result of the above information and taken into account the insufficient data or data not yet publicly available on the life cycle GHG emissions of c-Si PV systems in Ontario, and the existence of two geographically diverse manufacturing scenarios (i.e. China and Ontario) for cells, modules and BOS production, a possible approach to measure the life cycle GHG emissions for a solar PV system in Ontario is using an average estimate of a c-Si solar PV .systems made and installed in regions located in similar latitudes as Ontario, such as Southern Europe. McKenney et al. 2008 considering that Southern 
Europe latitudes are comparable to those of major Canadian cities, and suggested that similar PV systems performances could be expected.

Indeed, a meta-analysis methodology called LCA harmonization that reduces uncertainty and variability from LCAs results and provides a LCA GHG emissions average estimate (Hsu et al. 2012) is used by the National Renewable Energy Laboratory (NREL) from the US Department of Energy. NREL is leading the Life Cycle Assessment Harmonization project initiative to review and harmonize LCAs of electricity generation technologies. Additionally, harmonized life cycle GHG emissions for crystalline multi-silicon solar PV systems' recent studies (Fthenakis et al. 2011; Hsu et al. 2012) considered the necessity to reduce uncertainty around estimates and variability from the high volume of published results of solar PV generation systems, because of differences in methods and assumptions.

Hsu et al. 2012 conducted research using LCA harmonization that aligned several key performance characteristics, listed in Table 14, of 13 studies of crystalline silicon PVs that met minimum standards of quality, transparency, and relevance, after screening of 379 LCA's studies of PVs. The harmonization study followed the umbrella of the LCA harmonization study program led by US National Renewable Energy Laboratory. 


\section{Table 14 Harmonized parameters and its standard values for multi- crystalline Si PVs}

\begin{tabular}{lc}
\hline Parameters & Standard value \\
\hline $\begin{array}{l}\text { Solar Irradiation } \\
\left(\mathrm{kWh} / \mathrm{m}^{2} / \mathrm{yr}\right)\end{array}$ & 1,700 \\
Module efficiency $^{(1)}$ & \\
Multi-crystalline Si $^{\text {Performance ratio }}{ }^{(2)}$ & $13.2 \%$ \\
Rooftop $^{\text {Ground-mounted }}$ & 0.75 \\
System lifetime (years) & 0.80 \\
\hline
\end{tabular}

Source: Hsu et al. 2012 p S127 and 2012a p4

(1) Harmonized GHG medians of mono-c Si and multi-c Si technology types are likely similar.

(2) Ground-mounted and rooftop c-Si PVs have similar harmonized results suggesting that the type of mounting is not a large factor in GHG emissions.

The system boundaries used in the harmonization process included the upstream and the operational life cycle stages of multi-c Si PV systems, and excluded the downstream phase such as decommissioning, recycling, and waste disposal due to insufficient data and its negligible impact. Moreover, the LCA studies were harmonized to one location and it is assumed that the multi-c Si PV system is manufactured and installed in Southern Europe. The advantage of obtaining harmonized results is a more consistent foundation for comparing $\mathrm{c}-\mathrm{Si}$ PVs with conventional and other renewable electricity technologies. Nonetheless, 
future LCA harmonization studies should be conducted taking Chinese manufacturing into account, considering its role as a major supplier of PV modules (62\% of production world wide) and the impact of its more permissive environmental restrictions (Hsu et al 2012; Yue et al. 2014).

The harmonization methodology used equation 8 to calculate the GHG emissions for solar PVs:

$$
G H G=\frac{\mathrm{W}}{\mathrm{I} \times \eta \times \mathrm{PR} \times \mathrm{LT} \times \mathrm{A}} \quad \text { Eq. } 8
$$

Where, GHG is the GHG emissions per unit of electricity generated ( $\mathrm{g}$ CO2-eq/kWh), the numerator $\mathrm{W}$ represents the GHG emissions from all components and life cycle phases ( $\mathrm{g} \mathrm{CO} 2-\mathrm{eq}$ ), while the denominator calculates the electricity generated over the lifetime of the PV system obtained by the solar irradiation (I) $\left(\mathrm{kWh} / \mathrm{m}^{2} / \mathrm{yr}\right)$, the lifetime average module efficiency $(\eta)(\%)$, the performance ratio (PR), the system life time (LT) (yr), and the total module area (A) $\left(\mathrm{m}^{2}\right)$. In the harmonization process, several factors affecting the denominator are standardized, and GHG is recalculated based on these new factors, producing a "harmonized" result.

The individual harmonized result is calculated by dividing the study's recalculated GHG emissions by the harmonized lifetime electricity generated and the median is used as the main measure of variability. As a result, the study obtained a harmonized median life cycle GHG emissions estimate of 47 
$\mathrm{gCO}_{2} / \mathrm{kWh}_{\mathrm{AC}}$ for multi-crystalline silicon solar PVs; the published median estimate was $56 \mathrm{gCO} / \mathrm{kWh}_{\mathrm{AC}}$ (Hsu et al. 2012, pS129 and 2012a, p5).

The assumptions of this harmonization study are consistent and comparable with the assumptions of the mc-Si solar PV system case study in Ontario (Table 13), particularly, the PV system operation under Southern European conditions: solar irradiation of $1,700 \mathrm{kWh} / \mathrm{m}^{2} / \mathrm{year}$, and a performance ratio of 0.75 . Consequently, this research used the harmonized median life cycle GHG emissions estimate for multi-c Si solar PV systems calculated in Hsu et al. 2012 as the more consistent and current estimate of (multi-c Si) PVs life cycle GHG emissions.

Similarly, as part of the life cycle GHG emissions estimate for a multi-c Si solar PV system related to the operation phase, this research took into account the GHG emissions avoided as a consequence of the installation of new gridconnected solar PV generation units, since a baseload generation unit is shifted from the dispatch ranking of the Ontario's power grid. The current baseload generation technologies in Ontario's electricity grid are nuclear, hydroelectricity, and natural gas (simple cycle and combined cycle), the latter technology being the only emitter of $\mathrm{CO}_{2}$ to the atmosphere (IESO 2013). Therefore, the natural gas based generation units will be displaced and it is assumed the harmonized median life cycle GHG emissions estimate of $470 \mathrm{~g} \mathrm{CO} \mathrm{CO}_{2 \mathrm{eq}} / \mathrm{kWh}_{\mathrm{AC}}$ for a conventional natural gas power generation system (O'Donaughue et al. 2014) as 
the GHG emissions avoided by a multi-Si solar PV system. This harmonization study was conducted following the same NREL's LCA harmonization methodology explained above. This harmonized value comprised the life cycle GHG emission from natural gas-fired combustion turbine (simple cycle) and combined cycle systems. The boundary system of the study included the upstream stage (plant construction), the operation and maintenance (noncombustion phase), the fuel cycle, the combustion at power plant, and the downstream stage (decommissioning and disposal).

\subsubsection{Levelized Cost of Electricity (LCOE)}

The LCOE calculation is used in this graduate research to measure the cost-effectiveness of the Ontario's FIT solar PV program through a comparison between the LCOE (break-even point price) of each case study scenario with its corresponding average FIT rate.

\subsection{LCOE Methodology}

Branker et al. 2011, Hernandez-Moro and Martinez-Duart 2013 extensively reviewed and clarified the LCOE methodology for solar PV including realistic input assumptions and justifications. Calculating the LCOE requires a discount cash flow analysis and consideration of the cost of the electricity generation system and the electricity generated over its lifetime to provide a cost in $\$ / \mathrm{kWh}$ (or $\$ / \mathrm{MWh}$ or cents/kWh). The calculation method is expressed in equations (9) to (12) (Zweibel 2010; Branker et al. 2011; Reichelstein and 
Yorston 2013; Hernandez-Moro and Martinez-Duart 2013).

The LCOE as a constant value per year is equal to the sum of the present value of net costs divided by the electricity generated in equation 9. It should be noted that the summation calculation starts from $t=0$ to include the system capital cost at the beginning of the first year that is not discounted in equation 10 .

$\sum_{t=0}^{T}\left(\frac{L C O E_{t}}{(1+r)^{t}} x E_{t}\right)=\sum_{t=0}^{T}\left(C_{t} /(1+r)^{t}\right) \quad$ Eq. 9

$L C O E=\sum_{t=0}^{T}\left(C_{t} /(1+r)^{t}\right) / \sum_{t=0}^{T}\left(E_{t} /(1+r)^{t}\right) \quad$ Eq.10

The net cost of the system $\left(C_{t}\right)$ is disaggregated in cash outflows such as initial investment (equity and debt), operating and maintenance costs, and financing costs (interest payments) in equation 11. The net costs also consider cash flow inflow like government incentives such as investment tax credit and accelerate depreciation (Reichelstein and Yorston 2013); but this LCOE calculation will not considered any incentive because the LCOE will be compared with the Ontario's FIT program rate in the cost/benefit analysis. Likely, this LCOE calculation will not to be used to evaluate grid parity. Therefore the cash outflow will not consider transmission and connection fees (Branker et al. 2011).

$\left.L C O E=\sum_{t=0}^{T}\left(I_{t}+O_{t}+M_{t}+F_{t}\right) /(1+r)^{t}\right) / \sum_{t=0}^{T}\left(E_{t} /(1+r)^{t}\right) \quad$ Eq.11 
Even though it appears that the annual energy output is being discounted, it is just an arithmetic result to obtain a constant LCOE value in equation 9. The annual energy output is calculated by multiplying the annual rated electricity generation by the degradation factor $(1-d)^{t}$, which decreases the electricity generated with time (in equation 12)

LCOE $\left.=\sum_{t=0}^{T}\left(I_{t}+O_{t}+M_{t}+F_{t}\right) /(1+r)^{t}\right) / \sum_{t=0}^{T}\left(S_{t}(1-d)^{t} /(1+r)^{t}\right)$ Eq. 12

Where:

$C_{t}=$ Net cost of the project for $t(C A D \$)$

$I_{t}=$ Initial investment $(C A D \$)$

$\mathrm{O}_{\mathrm{t}} \& \mathrm{M}_{\mathrm{t}}=$ Annual operating and maintenance costs (CAD\$)

$F_{t}=$ Annual financing costs (CAD\$)

$E_{t}=$ Annual Energy output $(k W h)$

$\mathrm{S}_{\mathrm{t}}=$ Annual rated electricity generation $(\mathrm{kWh})$

$\mathrm{T}=$ project lifetime (years)

$\mathrm{t}=$ year $\mathrm{t}$

$r=$ Discount rate $(\%)$

$d=$ Degradation rate ((rate at which there is a reduction in output). 
The scope of this LCOE calculation includes the initial investment and annual costs and encompasses the upstream and operation phases of the multic Si solar PV system life cycles related to each case study's scenarios: fixedground-mounted commercial-scale, fixed-rooftop commercial-scale, and fixedground-mounted utility-scale in Ontario.

Other boundaries of this LCOE calculation are related to the net costs of the Ontario's solar PV system aforementioned, which will not take into account cash inflows and transmission and connection fees, and to the annual rated electricity generation calculation, which will not consider intermittency (limitation to be a base-load technology unless using an energy storage device) and timeof-day peak load patterns (high electricity production at the time of seasonal peak demand) (Reichelstein and Yorston 2013). However, the majority of the costs assumed in the calculation of the LCOE for each Ontario's solar PV system scenario were consistent to typical PV commercial and utility costs with detailed justifications and limitations.

Indeed, all costs, and other technical and performance assumptions are based on more recent Ontario and global PV market data, derived from a range of possible values, and represent a typical project. For that reason not all projects will match the typical project assumptions, and some project-specific data would either result in higher or lower LCOEs. 
The initial investment or capital cost for solar PV installation comprises the unit cost (manufacturing cost of the PV module production process), the BOS cost (mainly the inverter cost), installation cost (which include mostly labour costs), and owner cost (land to set up installation and transportation) (Das et al. 2012). The main generation cost for solar PV projects is the initial investment cost and the cost of financing the capital cost. The BOS system and labour cost represent $50 \%$ of initial investment cost (Branker et al. 2011).

The upfront capital costs to install a PV system or capital costs assumed for each scenario of the Ontario's FIT solar PV system case study are obtained from an NRCan research report (CanmetENERGY 2012), which provides final retail prices of turnkey installed solar PV systems in Ontario based on rooftop and ground-mounted commercial-scale installations. Regarding ground-mounted utility-scale installations, Reichelstein and Yorston 2013 assumed the same PV module price as a ground-mounted commercial-scale installation; however, BOS installation and owner's costs are considered $67 \%$ of rooftop commercial-scale installation costs, because of the economies of scale effects (Darling et al. 2011; NREL, 2011).

CanmetENERGY 2012 reported that the PV module retail price is CAD\$ $1.6 / \mathrm{W}_{\mathrm{DC}}$. Meanwhile the manufacturing cost that takes place in Ontario is only CAD $\$ 0.8 / \mathrm{W}$, which is related to the module assembly; it starts with finished cells. 
The retail prices of the components that are manufactured upstream of a multi-c solar PV module, such as silicon feedstock, ingots/wafers, and cells, are estimated in Powell et al. 2013. They developed a PV cost model that estimate the cost and price structures of standard multi-crystalline silicon PVs manufactured in United States (US), which is freely available from MIT Photovoltaic Research Laboratory.

Similar to modules, only the final assembly and testing of inverters (approximately $25 \%$ of the total sale price) are currently being done in Canada. This comes to approximately CAD $\$ 0.09$ to CAD $\$ 0.10 / \mathrm{W}$ (CanmetENERGY 2012).

The total capital cost of each installed solar PV system related to the Ontario FIT solar PV case study scenarios are disaggregated in Table 15 as manufacturing costs (silicon feedstock, wafer, cell and module production), BOS costs (inverters, racking/mounting and electrical components/wiring), installation (labour costs), and owner costs (land leasing, permitting, professional services, and consultants). All the values are expressed in CAD $\$ / W_{D C}$ (manufacturers quoted in nominal values). 
Table 15 Initial Investment of a solar PV system in Ontario $\left(I_{t}\right)^{1}$

\begin{tabular}{|c|c|c|c|}
\hline Initial Invetsment $\left(I_{t}\right)\left(C A D \$ / W_{D C}\right)$ & $\begin{array}{c}\text { Scenario } 1 \\
\text { (Groun-mounted, } \\
\text { commercial) }\end{array}$ & $\begin{array}{c}\text { Scenario } 2 \\
\text { (Rooftop, } \\
\text { commercial) }\end{array}$ & $\begin{array}{c}\text { Scenario } 3 \\
\text { (Ground-mounted, } \\
\text { utility) }\end{array}$ \\
\hline \multicolumn{4}{|l|}{ Manufacturing costs } \\
\hline Sillicon Feedstock (US standar) ${ }^{2}$ & 0.19 & 0.19 & 0.19 \\
\hline Ingots/ Wafers (US standar) ${ }^{2}$ & 0.32 & 0.32 & 0.32 \\
\hline Cells (US standar) $)^{2}$ & 0.28 & 0.28 & 0.28 \\
\hline Modules (Ontario) & 0.80 & 0.85 & 0.80 \\
\hline Modules & 1.6 & 1.7 & 1.6 \\
\hline \multicolumn{4}{|l|}{ BOS costs } \\
\hline Inverters (outside Ontario) & 0.26 & 0.26 & 0.14 \\
\hline Inverters (Ontario) & 0.09 & 0.09 & 0.09 \\
\hline Inverters & 0.35 & 0.35 & 0.23 \\
\hline Racking/mounting & 0.20 & 0.20 & 0.13 \\
\hline Electrical components, wiring & 0.26 & 0.26 & 0.17 \\
\hline Installation & 0.80 & 0.90 & 0.60 \\
\hline Owner'costs & 0.20 & 0.30 & 0.20 \\
\hline Tota Capital Costs (Ct ) (CAD\$/ W & 3.41 & 3.71 & 2.94 \\
\hline
\end{tabular}

Source:

(1) CanmetENERGY (2012)

(2) Powell et al. 2013; Bank of Canada 2014

The annual costs related to a solar PV system are usually fixed operating and maintenance costs including replacement of inverters (fuel cost is zero as well variable $\mathrm{O} \& \mathrm{M}$ costs), insurance, and financing costs. There is no variable O\&M cost since fuel consumption is null (Branker et al. 2011; NREL, 2011; Hernandez-Moro and Martinez-Duart, 2013).

The annual fixed O\&M costs for the entire lifetime of a typical solar PV system without trackers or mobile parts are usually minima and include occasional cleaning, performance monitoring, electrical system repair, and 
inverter replacement (Branker et al. 2011; Reichelstein and Yorston, 2013; Hernandez-Moro and Martinez-Duart 2013). Reichelstein and Yorston 2013 estimated fixed O\&M costs for US PV systems based on average reported values such as $0.92 \%$ of the total installed system cost for Si PV commercialscale systems and $0.75 \%$ for Si PV utility-scale systems, because the latter experiences economies of scale for the annual fixed cost components. Likewise, Branker et al. 2011 presented a case study of LCOE for a solar PV system in Ontario and assumed the inverter replacement (usually every 10 years), according to manufacturing warranty information, represents $9 \%$ of the total system capital cost (ranged from 6 to $9 \%$ in US for 2009).

Additionally, an annual insurance rate for a PV system is taken into account as an operating cost due to high technological risks linked to PV systems. Insurance cost is included as $0.25 \%$ of the total capital cost of the system (based on U.S insurance market information) (Zweibel 2010).

Regarding financing costs, solar PV technologies should be able to get similar financing methods (debt as loans or mortgages, and equity financing) as other energy technologies. For instance, to calculate the FIT rate OPA made some financial assumptions such as the $70 / 30$ debt/equity split and debtborrowing costs at 7\% (OPA 2010a). However, some project developers were presented with difficulties in finding financing for projects under the Ontario FIT (Branker et al. 2011). Therefore, the Ontario FIT solar PV system case study will 
assume $100 \%$ of equity financing to simplify discount rate calculations, and debtfinancing costs will not be considered.

The annual costs assumed as a percentage of the total capital cost of each Ontario FIT solar PV system case study scenario are disaggregated in Table 16. Otherwise, the annual costs had been escalating with an annual effective inflation rate of $2.25 \%$ (OPA 2010a).

\section{Table 16 Total annual costs}

\begin{tabular}{l|l|l|l|}
\hline Annual costs (\%) & $\begin{array}{l}\text { Scenario 1 } \\
\text { (Groun-mounted, } \\
\text { commercial) }\end{array}$ & $\begin{array}{l}\text { Scenario 2 } \\
\text { (Rooftop, } \\
\text { commercial) }\end{array}$ & $\begin{array}{l}\text { Scenario 3 } \\
\text { (Ground-mounted, } \\
\text { utility) }\end{array}$ \\
\hline $\begin{array}{l}\text { Operating and maintenance costs (O\&M) } \\
\text { Fixed O\&M costs }\end{array}$ & $0.92 \%$ & $0.92 \%$ & $0.75 \%$ \\
$\quad$ Insurance & $0.25 \%$ & $0.25 \%$ & $0.25 \%$ \\
\hline \hline Total Fixed 0\&M + Insurance costs & $1.17 \%$ & $1.17 \%$ & $1.00 \%$ \\
\hline \hline Inverter replacement, year 10th & $9.00 \%$ & $9.00 \%$ & $9.00 \%$ \\
\hline
\end{tabular}

The discount rate is the most relevant input parameter assumed to calculate the LCOE that takes into account the value of the money along the project's lifetime and the financial risk of investment, since it influences the investor's financial risk perception during a project selection process (Branker et al. 2011; Hernandez-Moro and Martinez-Duart 2013). Renewable technologies usually have high discount rates because of high technological risks; but the International Energy Agency (IEA) assumes traditional discount rates between 10\% and $12 \%$ for PV systems (Hernandez-Moro and Martinez-Duart 2013). 
In terms of corporate finance, if a project keeps the company's leverage ratio (Debt/Assets) constant during the project lifetime, the appropriate discount rate is the Weighted Average Capital Cost (WACC) (Reichelstein and Yorston 2013) that is expressed in equation 13 (Brealey and Myers 1998, p155).

$$
\mathrm{WACC}=r_{e} * \% E+r_{i} * \% D *(1-T) \quad \text { Eq. } 13
$$

Where,

$r_{e}=$ Cost of equity (cost of capital)

$\% \mathrm{E}=$ Percentage of project capital cost as equity

$r_{i}=$ Cost of debt

$\% \mathrm{D}=$ Percentage of project capital cost as debt

$\mathrm{T}=$ Income tax rate

As aforementioned, OPA developed a financial model to calculate the optimal FIT rate for the FIT program. OPA took into account typical renewable energy project capital costs, operating and maintenance costs, financing costs, and expected electricity production over the life of the project. The financial assumptions for typical FIT projects are shown in Table 17 (OPA 2010a). 
Table 17 Financial assumptions for a typical renewable energy project

\begin{tabular}{lc}
\hline Parameters & Value \\
\hline$\%$ of project capital cost as & $30 \%$ \\
equity investment (E/C) & \\
$\%$ of project capital cost as & $70 \%$ \\
debt (D/C) & \\
Rate of Return on equity & $11 \%$ \\
Cost of debt, repaid to bank & $7 \%$ \\
Income tax rate on profit & $30.5 \%$ \\
from equity investment & \\
Inflation rate & $2.25 \%$ \\
\hline
\end{tabular}

Source: OPA (2010a)

To validate the OPA's rate of return on equity of $11 \%$, equation 14 (Brealey and Myers 1998) and the corresponding assumptions in Table 18 are applied. The result obtained is $11.54 \%$ cost of equity, a similar value to that assumed by OPA.

$$
r_{e}=R_{f}+\beta\left(R_{m}-R_{f}\right) \quad \text { Eq. } 14
$$




\section{Table 18 Cost of equity assumptions}

\begin{tabular}{llc}
\hline & Definition & Value/Result \\
\hline $\mathbf{r}_{\mathbf{e}}$ & Cost of capital & $11.54 \%$ \\
$\mathbf{R}_{\mathbf{f}}$ & Rate of free risk (10-year US Government & $3 \%{ }^{1}$ \\
& Treasury Bonds) & \\
$\mathbf{R}_{\mathbf{m}}-\mathbf{R}_{\mathbf{f}}$ & Market Risk Premium (Canada Equity & $5 \%{ }^{1}$ \\
& Risk Premium) & \\
& R $_{\mathrm{m}}=$ Market Return & \\
$\boldsymbol{\beta}_{\boldsymbol{e}, \boldsymbol{L}}$ & Beta of equity, levered (in a specific & $1.7^{2}$ (US solar PV \\
& industry) & companies) \\
\hline
\end{tabular}

Sources:

(1) Damodaran 2014

(2) Goodrich et al. 2013

Considering equation 13 and the OPA's financial assumptions from table 17 , the WACC obtained is $6.71 \%$, a close result to the assumed cost of debt of $7 \%$, as a result of taking into account a high level of debt from the initial investment (70/30 debt/equity split). Similarly, if $100 \%$ equity financing of initial investment is assumed, the WACC will be $11 \%$ and the resulting LCOE is equal to the LCOE obtained from a (70/30) debt/equity ratio. Therefore, the Ontario's FIT solar PV case study assumed a cash flow without debt financing and a cost of capital (equity) of $11 \%$ as the discount rate of the cash flow. 
Degradation is an intrinsic characteristic of solar PV systems. The degradation rate is a percentage of initial capacity that remains available in a later year. Therefore, the solar PV system's energy production will decrease over its lifetime with an earlier, faster degradation and then it is stabilized (Branker et al. 2011; Hernandez-Moro and Martinez-Duart 2013;Reichelstein and Yorston, 2013). A degradation rate for $\mathrm{c}-\mathrm{Si}$ modules between $0.2-0.5 \%$ per year is considered reasonable given technological advances (Branker et al. 2011). Previous studies such as Branker et al. 2011 considered an annual degradation factor of $0.5 \%$ for a c-Si PV system in Ontario, and Reichelstein and Yorston's 2013 research study used a yearly degradation factor of $0.5 \%$ for commercial cSi PV systems and $0.35 \%$ for utility c-Si PV systems. The Ontario FIT solar PV system case study assumed a constant power degradation rate per year of $0.5 \%$ for the commercial scale scenario and $0.35 \%$ for the utility scale.

The project lifetime is assumed as 20 years. It was explained in the case study's assumptions section above .

The annual rated electricity generation $\left(\mathrm{kWh} \mathrm{h}_{\mathrm{AC}}\right)$ is calculated using the annual PV potential of each location of the Ontario's solar PV system scenarios (Ottawa and Toronto) obtained from a publicly available solar photovoltaic (PV) potential database of Canadian municipalities (NRCan nda) (see section 4.3.2,viii), the capacity factor for each location using equation 7 , and the values 
of the nominal system capacity $\left(\mathrm{kW}_{\mathrm{DC}}\right)$ for each scenario. Therefore, the annual rated electricity generation $\left(\mathrm{kW}_{\mathrm{AC}}\right)$ is determined by multiplying the total number of hours of the year $(8,760 \mathrm{~h})$ by the rated system size $(\mathrm{kW}$ DC $)$ and the capacity factor (\%) of the PV system for each location according to equation 6. Table 19 shows the annual rated electricity generation for each scenario. After calculation of the total electricity generation for the first year of operation, the corresponding annual degradation factor (d) and the annual discount rate (rate of return) are applied during all the project lifetime.

\section{Table 19 Annual rated electricity generation}

\begin{tabular}{|c|c|c|c|}
\hline Annual rated electricty generation $\left(\mathrm{S}_{\mathrm{t}}\left(\mathrm{kWh}_{\mathrm{Ac}}\right)\right.$ & Scenario 1 (Ottawa) & Scenario 2 (Toronto & Scenario 3 (Ottawa) \\
\hline Weighted Average Capaciy- Nominal ( $k W_{D C}$ ) (DC/AC factor=1.2) & 736 & 225 & 7,105 \\
\hline Annual PV potential for South-facing PV with latitude at tilt ( $k W h_{A C} / k W /$ year) & 1,198 & 1,161 & 1,198 \\
\hline Capacity Factor (\%) & $13.7 \%$ & $13.3 \%$ & $13.7 \%$ \\
\hline Annual Rated Electricity Generated $\left(\mathrm{S}_{\mathrm{t}}\right)\left(\mathrm{kWh} \mathrm{Ad}_{\mathrm{Ac}}\right)$ & 881,781 & 261,322 & $8,511,333$ \\
\hline
\end{tabular}

In summary, the discounted cash flow model calculates the LCOE required to cove the cost of investment, operating and maintenance costs, and earning a reasonable rate of return over a 20 -year contact term. This model uses a five-step process to calculate LCOE:

(i) Capital investment is estimated based on updated Ontario market information.

(ii) Annual fixed operating and maintenance expenses, including O\&M costs essentially the replacement of the inverter, are estimated (assuming fuel 
cost zero) adding the annual insurance cost for all the project lifetime and then deducting it from capital investment to arrive at estimate cash flow.

(iii) Annual generation output for the project lifetime is estimated based on the case study's nominal capacity and assumed capacity factor, and taking into account a PV module power degradation rate.

(iv) Cash flow and annual generation output are then discounted using the discounted rate of return on equity.

(v) LCOE is calculated by dividing the discounted cash flow by the discounted generation output.

\subsubsection{Cost/Benefit Analysis}

Using the LCSA approach, the value chain of the typical Ontario's FIT solar PV system was evaluated from an economic and environmental perspective taking into account the (environmental) LCA and LCC results. The next step of this value chain analysis is a cost/benefit analysis to obtain a net economic cost/benefit and a net environmental cost/benefit. The first one is called margin and is calculated using equation 15.

$$
E C_{B}-E C_{C}=M \quad \text { Eq. } 15
$$

Where, $\mathrm{EC}_{\mathrm{B}}$ is the economic benefit of the Ontario FIT solar PV life cycle expressed in CADc/kWh $\mathrm{AC}_{\mathrm{AC}}, \mathrm{EC}_{\mathrm{c}}$ is the economic cost of the Ontario FIT solar PV life cycle expressed in $\mathrm{CADc} / \mathrm{kWh} \mathrm{h}_{\mathrm{AC}}$, and $\mathrm{M}$ is the margin or the economic value 
of the Ontario FIT solar PV system value chain expressed in CADc/kWh $\mathrm{h}_{\mathrm{AC}}$.

Equation 16 calculates the net environmental benefits:

$$
E V_{B}-E V_{C}=N E B \quad \text { Eq. } 16
$$

Where, $\mathrm{EV}_{\mathrm{B}}$ are the environmental benefits expressed in $\mathrm{tCO}_{2 \mathrm{eq}}$ avoided in the Ontario's power grid during the Ontario FIT solar PV life cycle, $\mathrm{EV}_{\mathrm{c}}$ is the environmental costs expressed in $\mathrm{tCO}_{2 \mathrm{eq}}$ emitted during all the Ontario FIT solar PV life cycle, and NEB is the net environmental benefits of the Ontario FIT solar PV system expressed in $\mathrm{tCO}_{2 e q}$ avoided in the Ontario's power grid.

\subsubsection{Margin}

The economic benefits of each Ontario's FIT solar PV system during the project lifetime are the corresponding Weighted Average FIT solar PV rate for each scenario shown in Tables 20, 21 and 22. These average rates were calculated considering the OPA's FIT price schedules (OPA 2013d; OPA 2014a) and the weights with respect to capacity assumed in section 4.3.2. 
Table 20 Weighted Average FIT solar PV rate (CADc/kWh $\mathrm{hC}_{\mathrm{AC}}$ )- Scenario 1

\begin{tabular}{|l|c|c|c|}
\hline Contract Type & $\begin{array}{c}\text { Mean Average FIT solar } \\
\text { PV rate CADc/kWh }\end{array}$ & $\begin{array}{c}\text { Weights with respect } \\
\text { to capacity }\end{array}$ & $\begin{array}{c}\text { Weighted Average FIT } \\
\text { solar PV rate } \\
\text { CADc/kWh }\end{array}$ \\
\hline FIT $^{1}$ & 58.25 & 0.40 & 41.58 \\
FIT 2 $^{1}$ & 44.32 & 0.21 & 3.76 \\
FIT 3 $^{2}$ & 32.07 & 0.39 & 6.45 \\
\hline \hline Total FlT solar PV rate 2009-2013 & \multicolumn{1}{|c|}{${ }^{1}$} & 1 & 51.80 \\
\hline
\end{tabular}

Source:

(1) OPA 2013d

(2) OPA 2014a

Table 21 Weighted Average FIT solar PV rooftop rate (CADc/kWh $\mathrm{h}_{\mathrm{AC}}$ )-

\section{Scenario 2}

\begin{tabular}{|c|c|c|c|}
\hline Contract Type & $\begin{array}{c}\text { Mean Average FIT } \\
\text { rooftop rate CADc/kWh }\end{array}$ & $\begin{array}{c}\text { Weights with respect } \\
\text { to capacity }\end{array}$ & $\begin{array}{l}\text { Weighted Average FIT } \\
\text { rooftop rate CADc/kWh }\end{array}$ \\
\hline FIT $1^{1}$ & 62.90 & 0.40 & 25.40 \\
\hline FIT $2^{1}$ & 52.47 & 0.21 & 11.01 \\
\hline $\mathrm{FIT}^{2}$ & 33.70 & 0.39 & 13.02 \\
\hline $\begin{array}{l}\text { Total FIT solar PV rooftop rate } \\
2009-2013\end{array}$ & & 1 & 49.43 \\
\hline
\end{tabular}

Source:

(1) OPA 2013d

(2) OPA 2014a

Table 22 Weighted Average FIT solar PV ground-mounted rate $(\mathrm{CADc} / \mathrm{kWh}$ AC)-Scenario 3

\begin{tabular}{|c|c|c|c|}
\hline Contract Type & $\begin{array}{c}\text { Mean Average FIT } \\
\text { ground-mounted rate } \\
\text { CADc/kWh }\end{array}$ & $\begin{array}{c}\text { Weights with respect } \\
\text { to capacity }\end{array}$ & $\begin{array}{c}\text { Weighted Average FIT } \\
\text { ground-mounted rate } \\
\text { CADc/kWh }\end{array}$ \\
\hline FIT $1^{1}$ & 44.30 & 0.90 & 40.04 \\
\hline FIT $2^{1}$ & 36.17 & 0.01 & 0.30 \\
\hline${\text { FIT } 3^{2}}^{2}$ & 28.80 & 0.09 & 2.53 \\
\hline $\begin{array}{l}\text { Total FIT solar PV ground- } \\
\text { mounted rate 2009-2013 }\end{array}$ & & 1 & 42.87 \\
\hline
\end{tabular}

Source:
(1) OPA 2013d
(2) OPA 2014a 
The economic costs of each Ontario's FIT solar PV system during the project lifetime are the LCOE for each scenario calculated in section 4.3.3.2.1. Then, the margin or the economic value of the Ontario's FIT solar PV system value chain is calculated using equation 15.

\subsubsection{Net Environmental Benefit}

Since the environmental LCA metric known as life cycle GHG emissions represents the environmental costs generated for each $k W h_{A C}$ output of the multi-crystalline silicon solar PV system life cycle, the total environmental costs or total $\mathrm{GHG}$ emissions (in terms of $\mathrm{tCO}_{2}$ eq.) are calculated by multiplying the life cycle GHG emissions, assumed in this case study as the harmonized median life cycle GHG emissions estimate of $47 \mathrm{gCO}_{2} / \mathrm{kWh}$ for multi-crystalline silicon solar

PVs by the total solar PV electricity generated correspondent to each scenario calculated in Table 19.

Similarly, the environmental benefits are calculated by multiplying the harmonized median life cycle GHG emissions estimate of $470 \mathrm{~g} \mathrm{CO}_{2} / \mathrm{kWh}$ for conventional natural gas power generation system by the total solar PV electricity generated correspondent to each scenario calculated in Table 19. 


\section{CHAPTER V}

\section{RESULTS}

\subsection{Comparative policy analysis}

The comparative policy analysis was performed using a set of sustainability criteria to measure the likely effectiveness and sustainability performance of FIT solar PV policy frameworks in the selected jurisdictions, Germany, Spain and Ontario. According to several studies (Lipp 2007; Cory 2009; Evans et al. 2009; Laird and Stefes 2009; Mendonca et al. 2009, p.xxvii; and Maxim 2014), the success factors by which FIT programs can be measured as policy instruments to promote RET are directly related to reaching sustainability objectives. The criteria for each sustainability dimension used to evaluate FIT policy are listed below:

(i) Economic:

- Competitive LCOEs

- Developing a local manufacturing and export RE industry

- Investor security (level of rate of return on investment)

(ii) Social:

- Creation of green jobs

- Empowering communities

(iii) Political:

- Commitment to RE deployment

- Increase energy security (increasing electricity market share of RE) 


\section{(iv) Environmental:}

- GHG emissions reductions

Based on the literature review in sections 2.3, 2.4, 2.5 and 2.6 and according to the sustainability criteria listed above, a comparison of the level of accomplishment of each FIT policy jurisdiction is shown in Table 23.

According to the studies mentioned previously, the four main factors of success of FIT programs are: energy security, RE industrial development, job creation and reduction of $\mathrm{CO} 2$ emissions. Therefore, Germany has demonstrated that it is a world leader in implementing and developing a FIT policy program with long-term objectives related to energy security and reduction of their carbon footprint through deployment of RET. Meanwhile, Spain displayed a weakness in carbon footprint reduction and Ontario showed weaknesses in areas such as reduction of LCOE and the development of an RE industry with the creation of green jobs.

The following sections provide a descriptive comparison of the Ontario FIT policy with the corresponding FIT policies in Germany and Spain. 
Table 23 Level of accomplishment by FIT policy comparator

\begin{tabular}{lccc}
\hline Criteria & Germany & Spain & Ontario \\
\hline Competitive LCOE & $\sqrt{ } \sqrt{ }$ & $\sqrt{ }$ & $\sqrt{ }$ \\
RE industry & $\sqrt{ }$ & $\sqrt{ }$ & $\sqrt{ }$ \\
Investor security & $\sqrt{ }$ & $\sqrt{ }$ & $\sqrt{ } \sqrt{ }$ \\
Green jobs & $\sqrt{ } \sqrt{ }$ & $\sqrt{ }$ & $\sqrt{ }$ \\
Communities & $\sqrt{ } \sqrt{ }$ & $\sqrt{ } \sqrt{ }$ & $\sqrt{ } \sqrt{ }$ \\
Political commitment & $\sqrt{ } \sqrt{ }$ & $\sqrt{ } \sqrt{ }$ & $\sqrt{ }$ \\
Energy security & $\sqrt{ } \sqrt{ }$ & $\sqrt{ } \sqrt{ }$ & $\sqrt{ } \sqrt{ }$ \\
GHG emissions reductions & $\sqrt{ } \sqrt{ }$ & $\sqrt{ }$ & $\sqrt{ } \sqrt{ }$ \\
\hline
\end{tabular}

Where, the level of accomplishment is interpreted as follows:

$\sqrt{ } \sqrt{ }=$ High

$\sqrt{ } \sqrt{ }=$ Medium

$\sqrt{ }=\mathrm{LoW}$

\subsubsection{Comparison with Germany FIT program}

While Germany's renewable electricity sector is a mature market with 20 years of experience and growth under different policy incentives and Ontario's renewable sector is still in its mid-life, the development of Ontario's FIT program has many similarities with Germany's FIT program. These similarities include: offering similar rates (transparent and guaranteed long term prices) for most renewable energy technologies, in particular wind and solar (Table 28); prices are calculated based on an estimated rate of return (ROR) (Germany used 5-7\% and Ontario $11 \%$ in their tariff calculations); encouraging small scale projects in communities by offering fair rate to cover cost investments; adjusting rates out- 
of-the schedule depending on changes in technological costs; community participation and differentiated rates; and both jurisdictions are developing a strong manufacturing sector direct to export renewable technologies (Mabee et al. 2011; Yatchew and Baziliauskas 2011).

On the other hand there are some differences such as the balanced distribution of the renewable electricity portfolio in the German experience as compared to Ontario where wind power leads the portfolio, and the price degression strategy in the German FIT program as compared to Ontario's price escalation strategy with the exception of solar PV technology. The German degression rate is a gradual and incremental percentage, which reduces the tariff paid to developers by a set rate. This degression percentage is linked to solar PV cost reductions and learning effects for newly installed solar PV installations. Meanwhile the Ontario's FIT solar PV rate reductions are results of FIT rate revisions (del Rio Gonzalez and Gual 2007; Mabee et al. 2011; Yatchew and Baziliauskas 2011).

Table 24 International rate comparison (CADc/ kWh)

\begin{tabular}{lll}
\hline & Germany & Ontario \\
\hline Wind Onshore & $7-12.9$ & 11.5 \\
Solar PV & $13.7-19.8$ & $28.8-39.6$ \\
\hline
\end{tabular}

Source: RESLegal 2014; OPA 2014; Bank of Canada 2014 


\subsubsection{Comparison with Spain FIT program}

Spain is one of the most active countries in promoting electricity from renewable sources, particularly wind. The main reasons for this success are related to a strong social and political coalition, high interactions between stakeholders such as government, RE generators, financial institutions, research community, regional governments, environmental non-governmental organizations (NGO's), labour unions and agricultural organizations to support political commitment, and continuity of FIT during two successive reforms since the program was launched in 1998, and the specific elements of design of FIT as result of the consensus achieved (del Rio Gonzalez 2008).

Achieving efficiency and cost-effectiveness (increasing deployment of RE without leading to excessive windfall profits for RE investors) and lowering the burden for consumers are policy goals which have been reached by setting adequate rates at a level that satisfied both conflicting goals, and revising rates every 4 years with a constant assessment of technology costs. These objectives have been achieved. RE represented $22 \%$ of total electricity market sales in December 2006 and $96 \%$ of wind generation goes to the market as a result of an increased transparency of the price-formation mechanism. Also, the FIT rates are updated annually with indexation to the CPI as in Ontario's FIT experience (del Rio Gonzales and Gual 2007; del Rio Gonzalez 2008). 
Stability of the grid, when intermittent RE plants such as wind facilities are connected, is an important issue to be solved by the system operator, RE generators, and policy makers. After many years of tension and disagreements between these actors, Spanish FIT policy considered a penalty for deviations (5\%) of the expected RE feed to the grid 1 hour in advance of the market opening to support integration of RE and the stability of the system. In addition, the system operator has created the Centre for the Control of the Special Regime, which facilitates the management of an increasing share of intermittent RE generation (del Rio Gonzalez 2008).

FIT systems in Ontario and Spain present differences mainly related to rates. Ontario's FIT program offers a fixed rate, while Spain's program offers a double option, a fixed tariff and a variable or premium tariff relative to the market price. In Ontario ratepayers fund payments to FIT projects, while in Spain projects are funded by both ratepayers and taxpayers. Spain also has risk-based pricing, and it also lowers prices when the volume for a given technology reaches a target. Like Ontario, Spain does not use degression, relying instead on periodic reviews of pricing. Ontario will review prices every two years, while Spain reviews pricing every four years or more frequently, depending on the technology (Yatchew and Baziliauskas 2011). 


\subsubsection{Lessons for Ontario}

Ontario's Green Energy and Green Economy Act could benefit from lessons learned in the German system, especially with regard to degression of feed-in tariff rates over time, which could significantly reduce payments to developers over the course of a contract, and in turn encourage greater competitiveness among renewable power providers in the future. Besides, it is important to promote a balanced, diversified, and sustainable RE portfolio according to a long-term energy plan, as was achieved in Germany.

In spite of the differences between the Spanish and Ontario FIT program, an important lesson is to learn about the successful process of designing and implementing the Spanish FIT program and how it overcame regular FIT implementation concerns such as high deployment of renewable technologies with low burden to consumers, and access to the grid as a result of interactions, participation and consensus between three principal stakeholders government, RE generators and the grid manager. Therefore, in order to continue pursuing adequate deployment of renewable technologies Ontario's FIT program should minimize asymmetric information when pricing renewables, manage opposition to renewable energy during implementation, and balance policy stability with adaptive management in conjunction with community (aboriginal, co-ops, agricultural organizations) and public sector participation. 
Accelerated deployment of RE technologies is influenced by decreasing renewable costs, especially solar technology, so as to be politically sustainable.

Investor security is a constant objective during implementations of FIT systems, which is provided through the political signals of continuity of FIT programs. This encourages long-term investments at moderate costs. Even if policy makers have made successive reforms the structure of the system has to be maintained, such as in the Spanish case. Reduction of uncertainty is also provided through RE targets that encourage local manufacturers to mass production and economies of scale to reduce costs of renewable technologies.

Transparency of rate formation and avoidance of asymmetric information to RE investors is crucial to policy stability and consequently spur investment as well as maintaining FIT design principles such as prices declining over time, since cost reductions through innovation and learning should be occurring.

Community participation is a pattern in the analyzed countries. Interactions between stakeholders with different and opposing interests can achieve consensus regarding deployment of RE technologies, reduce discretionary rate formation and address opposition groups' concerns. 
In the political context, Ontario needs more federal support by introducing a policy similar to the European Directive on Renewable Energy to aggressively encourage the development of RE projects as happened in Germany and Spain, and influence decision making of manufacturers of renewable technologies who are considering establishing operations in Ontario (Mabee et al. 2011; Stokes 2013).

\subsection{Case study: Analysis of the value chain of the FIT solar PV in Ontario}

The main results and observations as a consequence of the value chain analysis of the FIT solar PV in Ontario are described below:

I. The core value chain activities should be identified as the PV module manufacturing (including BOS) and the operation phase because these activities produce the major costs and benefits during all the solar PV project lifetime. The PV module and BOS production costs represent $71 \%$ of the total capital cost, meanwhile the solar PV project revenues correspond to $100 \%$ of the FIT rate for a 20 -year contract with OPA.

II. The economic cost of each FIT solar PV system in the case study is the corresponding LCOE calculated for each scenario of the case study, i.e.

$42 \mathrm{CADc} / \mathrm{kWh}_{\mathrm{AC}}$ (scenario 1), $48 \mathrm{CADc} / \mathrm{kWh}_{\mathrm{AC}}$ (scenario 2), and 36 $\mathrm{CADc} / \mathrm{kWh}_{\mathrm{AC}}$ (scenario 3). The LCOE calculations for each scenario of the Ontario's FIT solar PV case study are shown in Tables 25 to 27 and appendices 3 to 5 . 


\section{Table 25 LCOE Calculation (Scenario 1)}

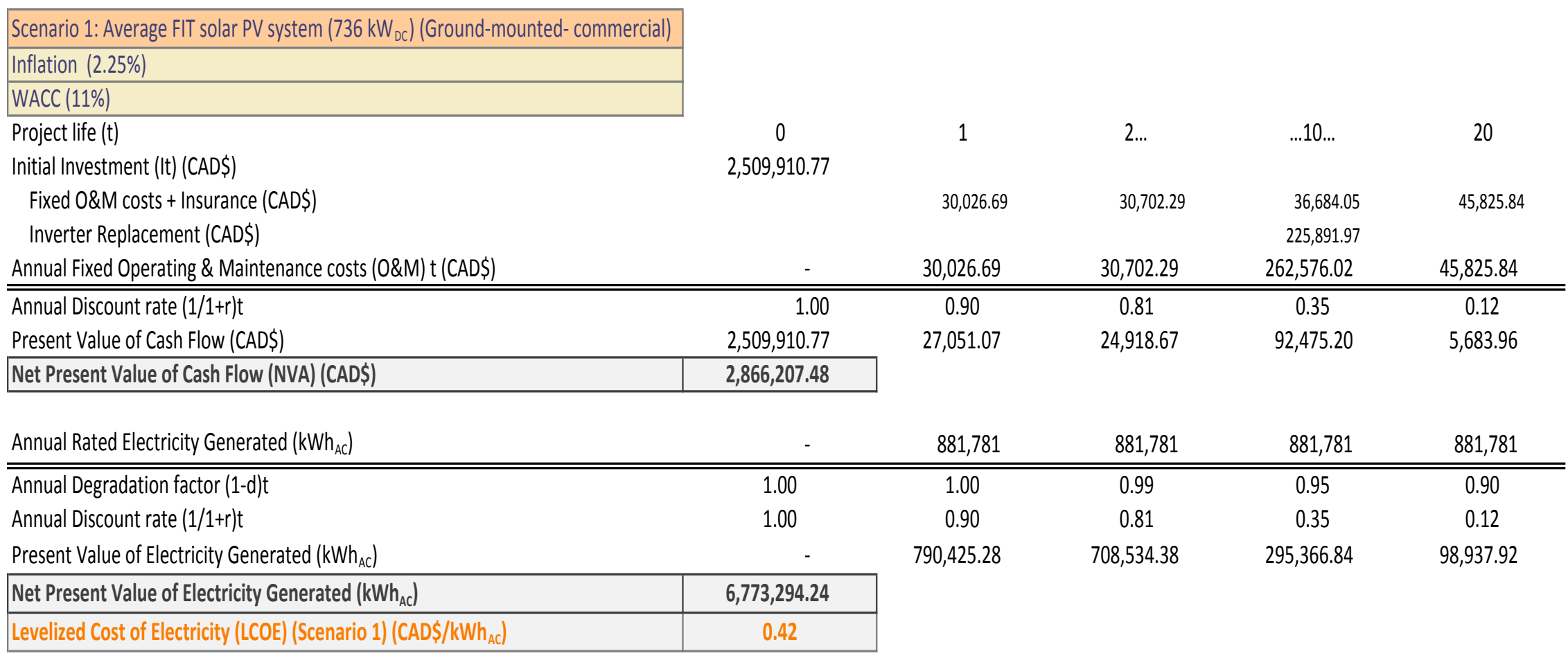




\section{Table 26 LCOE Calculation (Scenario 2)}

\begin{tabular}{|l|}
\hline Scenario 2: FIT Rooftop solar PV system $\left(225 \mathrm{~kW}_{\text {Dc }}\right.$ ) - commercial \\
\hline Inflation $(2.25 \%)$ \\
\hline WACC $(11 \%)$ \\
\hline
\end{tabular}

Project life $(\mathrm{t})$

Initial Investment (It) (CAD\$́)

0

Fixed 0\&M costs + Insurance (CAD\$)

$835,058.44$

Inverter Replacement (CAD\$)

Annual Fixed Operating \& Maintenance costs (O\&M) t (CAD\$)

$\begin{array}{lllll}9,990.01 & 10,214.79 & 12,204.95 & 15,246.46\end{array}$

Annual Discount rate

Present Value of Cash Flow (CAD\$ )

(NVA) (CAD\$)

1.00

$9,990.01$

Net Present Value of Cash Flow (NVA) (CAD\$\$)

$835,058.44$

0.90

$10,214.79$

$87,360.21$

$15,246.46$

Annual Rated Electricity Generated $\left(k W h_{A c}\right)$ $953,599.94$

Annual Degradation factor (1-d)t 1.00

Annual Discount rate $(1 / 1+r) t$

1.00

0.81

0.35

0.12

Present Value of Electricity Generated ( $\left.k W h_{A c}\right)$

\begin{tabular}{c}
- \\
1.00 \\
1.00 \\
- \\
\hline, 309.79 \\
0.48
\end{tabular}

261,322

$30,766.91$

$1,891.08$

Net Present Value of Electricity Generated $\left(\mathrm{kWh}_{\mathrm{AC}}\right)$

$234,247.67$

0.99

261,322

261,322

261,322

Levelized Cost of Electricity (LCOE) (Scenario 2) (CAD\$\$ $/ \mathrm{kWh}_{\mathrm{AC}}$

0.48


Table 27 LCOE Calculation (Scenario 3)

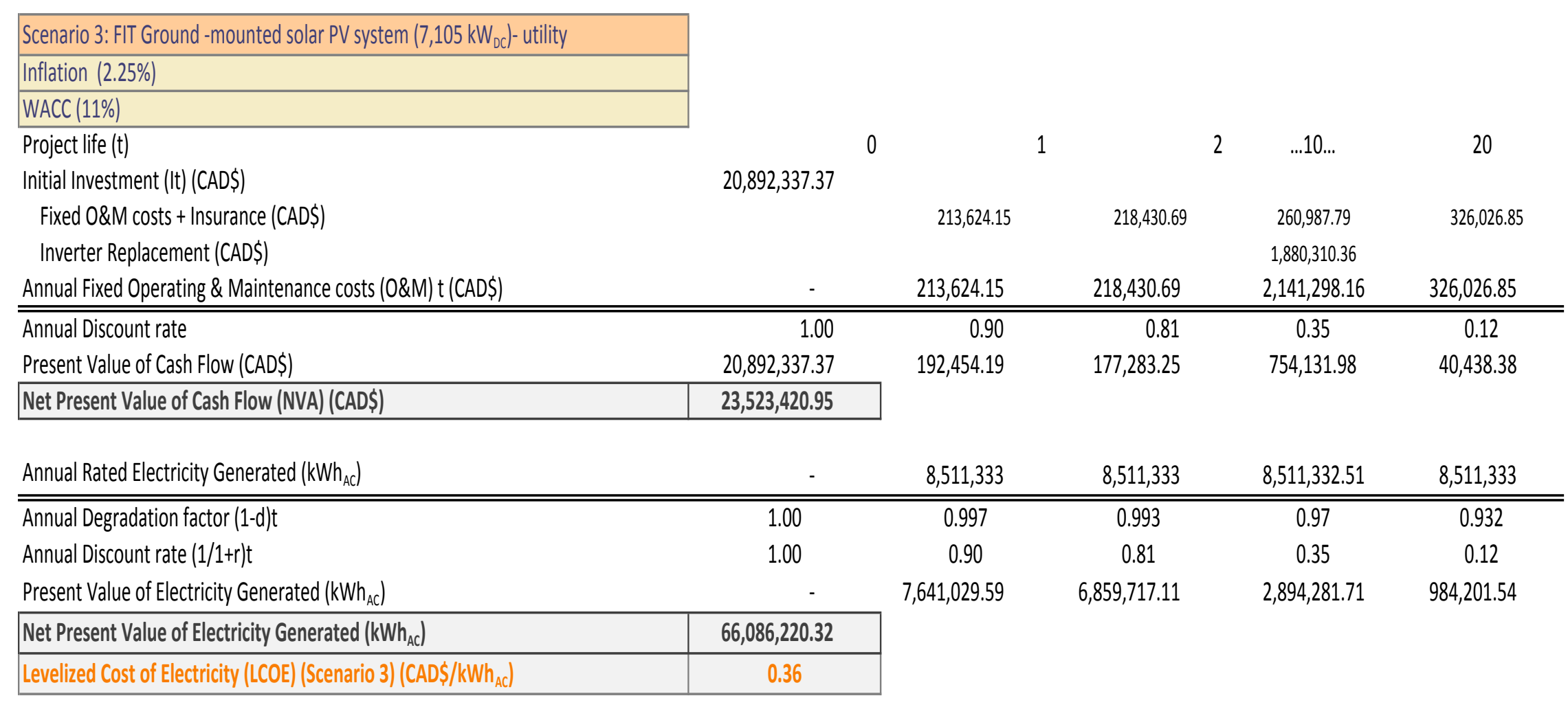


III. The environmental benefits and environmental costs of each scenario of the case study are shown in Table 28 , i.e. $7,867 \mathrm{tCO}_{2 \text { eq }}$ avoided and 787 $\mathrm{tCO}_{2 \text { eq }}$ generated (scenario 1); 2,331 $\mathrm{tCO}_{2 \text { eq }}$ avoided and $231 \mathrm{tCO}_{2 \mathrm{eq}}$ generated (scenario 2); and $189,328 \mathrm{tCO}_{2 \text { eq }}$ avoided and $18,933 \mathrm{tCO}_{2 \mathrm{eq}}$ generated (scenario 3).

\section{Table 28 Environmental Benefits and Environmental Costs}

\begin{tabular}{|c|c|c|c|}
\hline Energy output $\left(\mathrm{KWh}_{\mathrm{AC}}\right)$ & Scenario 1 & Scenario 2 & Scenario 3 \\
\hline Annual Rated Electricity Generated $\left(\mathrm{kWh}_{\mathrm{AC}}\right)$ & 881,781 & 261,322 & $20,892,337$ \\
\hline Project life time (yrs) & 20 & 20 & 20 \\
\hline Degradation factor (d\%) & $0.50 \%$ & $0.50 \%$ & $0.35 \%$ \\
\hline Total Solar PV Electricity Generated to the Grid $\left(\mathrm{kWh}_{\mathrm{AC}}\right)$ & $16,738,420$ & $4,960,540$ & $402,825,970$ \\
\hline $\begin{array}{l}\text { Environmental Benefits (tCO2eq) } \\
\text { Harmonized median life cycle } \mathrm{GHG} \text { emissions for conventional natural gas } \\
\text { power generation system }\left(\mathrm{gCO}_{2 \mathrm{eq}} / \mathrm{kWh}_{\mathrm{AC}}\right)\end{array}$ & & 470 & \\
\hline $\begin{array}{l}\text { Total Life Cycle GHG Emissions avoided for a conventional natural gas } \\
\text { power generation system }\left(\mathrm{tCO}_{2 \mathrm{eq}}\right)\end{array}$ & 7,867 & 2,331 & 189,328 \\
\hline $\begin{array}{l}\text { Environmental Costs (tCO2eq) } \\
\text { Harmonized median life cycle GHG emissions for multi-c Si solar PV } \\
\text { system (CO2eq/ } \mathrm{kWh}_{\mathrm{AC}} \text { ) }\end{array}$ & & 47 & \\
\hline Total Life Cycle GHG Emissions generated for a multi-c Si solar PV (t $\mathrm{tCO}_{2 \mathrm{eq}}$ & 787 & 233 & 18,933 \\
\hline
\end{tabular}

IV. The cost/benefit results expressed as an economic margin or profit obtained for each scenario of this case study, which considered typical FIT solar PV systems according to size, type of installation and market segment, led to positive margins of $9.5 \mathrm{CADc} / \mathrm{kWh}_{\mathrm{AC}}$ (average size for the FIT solar PV program), $1.9 \mathrm{CADc} / \mathrm{kWh}_{\mathrm{AC}}$ (average FIT rooftop PV installation) and 7.3 $\mathrm{CADc} / \mathrm{kWh}_{\mathrm{AC}}$ (average FIT ground-mounted PV installation). The margin (economic value) and the net environmental benefit of the Ontario's FIT solar PV system value chain for each scenario of the case study are reported in Table 29. 
Table 29 Cost/Benefit results for the Ontario's FIT solar PV system case study

\begin{tabular}{|c|c|c|c|}
\hline \multirow[b]{2}{*}{ COST/BENEFIT ANALYIS } & \multirow[b]{2}{*}{$\begin{array}{l}\text { FIT solar PV Program } \\
\text { Scenario } 1\left(611 \text { kW }_{\text {Ac }} \text { : }\right. \\
\text { Ground-mounted, } \\
\text { Commercial-scale } \\
\text { Ottawa } \\
\end{array}$} & \multicolumn{2}{|c|}{ Sensitivity Analysis } \\
\hline & & $\begin{array}{l}\text { Scenario2 }\left(187 \mathrm{~kW}_{\mathrm{AC}}\right) \text { : } \\
\text { Rofftop, Commercial- } \\
\text { scale } \\
\text { Toronto }\end{array}$ & $\begin{array}{l}\text { Scenario } 3\left(5,897 \mathrm{~kW}_{\mathrm{AC}}\right) \text { : } \\
\text { Ground-mounted, Utility- } \\
\text { scale } \\
\text { Ottawa }\end{array}$ \\
\hline Margin (CADC/KWh ${ }_{\mathrm{AC}}$ ) & \multirow{4}{*}{51.80} & \multirow{4}{*}{49.43} & \multirow{4}{*}{42.87} \\
\hline Economic benefits (CADc/ $/ \mathrm{kWh}_{\mathrm{AC}}$ ) & & & \\
\hline Weighted average FIT solar PV rate & & & \\
\hline Economic costs (CADc/kWh & & & \\
\hline Levelized cost of electricty (LCOE) & 42.32 & 47.51 & 35.60 \\
\hline Margin FIT solar PV value chain & 9.48 & 1.92 & 7.28 \\
\hline Net Environmental Benefits $\left(\mathrm{tCO}_{2 \mathrm{eq}}\right)$ & \multirow{4}{*}{7,867} & \multirow{4}{*}{2,331} & \multirow{4}{*}{189,328} \\
\hline Environmental benefits ( $\mathrm{CO} 2_{\text {eq }}$ ) & & & \\
\hline Harmonized median life cycle GHG emisisons avoided & & & \\
\hline Environmental costs ( $\mathrm{t} \mathrm{CO} 2_{\text {eq }}$ ) & & & \\
\hline Harmonized median life cycle GHG emisisons & 787 & 233 & 18,933 \\
\hline Net environmental benefits FIT solar PV value chain & 7,080 & 2,098 & $\overline{170,395}$ \\
\hline
\end{tabular}

V. The economic effect of offsetting the carbon credits (GHG emissions reductions) for each solar PV project in this case study is estimated as $1.06 \mathrm{CADc} / \mathrm{kWh}_{\mathrm{AC}}$. Taking into account that a current carbon offsetting market in Ontario to trade carbon credits does not exist, it is assumed the carbon pricing of $25 \mathrm{CAD} / \mathrm{CO}_{2}$ tonne from the current B.C Cap-and-Trade scheme (Pacific Carbon Trust 2014) can be used to simulate the possible economic benefits from solar PV projects in this case study. As a result of the above information, the net environmental benefits represent an increase in the economic margin of over $11 \%, 55 \%$, and $15 \%$ for each scenario $(1-3)$ of the FIT solar PV value chain case study. 


\subsection{Significance of findings}

Potential applications of this research to the practical work of the environmental policy and management fields are listed below:

\section{Contributes to the body of literature}

Even though there are several studies that provide a qualitative evaluation of the effectiveness and sustainability performance of FIT policy through an international comparative policy analysis, this study has proposed a set of sustainability criteria to provide an insight of the level of success of the Ontario's FIT in promoting solar PV technology.

Although there is an extensive body of literature regarding LCOE of solar PV technology, this research has filled the knowledge gap about the economic evaluation of the Ontario's solar PV value chain under a cost/benefit approach and the perspective of a life cycle sustainability assessment.

In addition, this study has provided an integrated assessment using both the qualitative and the quantitative assessment of the effectiveness and sustainability of Ontario's FIT solar PV program. 


\section{Facilitates more understanding of how Ontario's FIT program has promoted solar PV technology in the province.}

This study has provided an insight of the level of success of the Ontario's FIT in promoting solar PV technology. Ontario's FIT solar PV program has been effective and has contributed to a sustainability performance with strengths and weaknesses in the design and implementation of the program in comparison with FIT world leaders. The strengths are related to energy security, reduction of carbon footprint, investor security, and community participation. Meanwhile, the weakness areas of the Ontario's FIT program that need to be improved are the need to achieve competitive LCOEs and strengthen Ontario's RE industry with a focus on solar PV technology that will increase the number of green jobs in the Province.

III. Provides policy makers with further information on the quantitative analysis of the FIT solar PV in Ontario using an economic analysis of the solar PV value chain with insights on market behaviour.

The LCOE results demonstrate that solar PV technology is not yet cost competitive in comparison with other conventional electricity generation technologies in Ontario. Considering the current Ontario wholesale market price, which is the average weighted Hourly Ontario Electricity Price (HOEP) - 5.32 CADc/kWh $h_{A C}$ in July 2014 (IESO 2014) - the extra cost should range from 31 to $43 \mathrm{CADc} / \mathrm{kWh}$ AC. That is close to the current FIT solar PV price schedule $(29-40$ $\mathrm{CADc} / \mathrm{kWh}$ AC) (OPA 2014a). This extra cost is prorated to be part of the Global 
Adjustment price to be paid for all of the electricity consumers, which represents the difference between HOEP and the total contract generation, including renewables, and energy conservation projects (IESO 2014).

The margin results show an over-payment to solar PV projects with respect to the FIT rate. This risk premium is not only applied to ground-mounted utility-scale projects, which obtained an economic margin of $17 \%$ over its corresponding FIT rate, but also to rooftop commercial-scale projects that earned a risk premium of $4 \%$ over its corresponding FIT rate. These additional and constant profits have been paid to the solar PV contract holders for 20 years of the contract with OPA.

Regarding market behaviour, Ontario's FIT ground-mounted solar PV projects $\left(925 \mathrm{MW}_{\mathrm{Ac}}\right)$ have the largest market share with $71 \%$ of total FIT projects under contract and have received more benefits per electricity generated than rooftop projects $\left(6 \mathrm{CADc} / \mathrm{kWh}_{\mathrm{AC}}\right)$. It is noted that these projects also exhibit oligopolistic market behaviour because of the high market share concentration $(81 \%)$ of the total ground-mounted projects by the seven largest ground-mounted contract holders (four Canadian companies and three American subsidiaries in Table 2). Moreover, the total margin obtained by these solar PV ground-mounted contract holders is distributed equally between these Canadian and American project developers. 
IV. Integrates economic and environmental sustainability indicators.

Solar PV technology presents several benefits related to energy security and social and environmental sustainability. These benefits can be economically internalized in cost calculations to bring a more accurate economic evaluation. Thus, one of the applications of this research was to perform an economic analysis of the FIT solar PV value chain in Ontario considering not only the economic effect but also the net environmental benefit expressed in economic benefit terms. 


\section{CHAPTER VI}

\section{CONCLUSIONS, IMPLICATIONS AND FUTURE RESEARCH}

\subsection{Conclusions}

This study compared FIT experiences in Germany and Spain with respect to Ontario to determine how Ontario's FIT program, as policy instrument, has worked to promote solar PV technology in the Province and draw important lessons regarding implementation of FIT programs. This qualitative analysis was conducted using a set of sustainability criteria to evaluate and analyze the effectiveness and sustainability of Ontario's FIT solar PV policy, as well.

Among the sustainability criteria proposed based on the international experience, there are four that provide an insight into the level of success of a FIT policy: energy security, development of RE industry, creation of green jobs, and GHG emissions reductions.

Energy security considers how to ensure electricity supply in the long term. One option is through the development of RET. A successful FIT policy is when RETs can achieve a high electricity market share with its corresponding GHG emissions reductions. Solar PV technology in Ontario as well as in Germany has showed this tendency with long-term targets for 2032 and 2050, respectively. 
However, Ontario has not yet developed a strong solar PV industry reflected directly by the creation of green jobs as Germany did. Also, Ontario's FIT solar PV program needs to achieve a competitive LCOE in order to reach grid parity.

In addition to the comparative policy analysis performed in this thesis, a quantitative assessment of the effectiveness and sustainability of the Ontario's FIT solar program was conducted. Considering that the most relevant quantitative criteria to assess FIT policy is under the economic and environmental perspectives, this research performed a quantitative assessment of the economic-environmental effects along the different stages of the value chain for the solar PV industry in Ontario to indicate the costs/benefits to the Province.

The economic analysis of the Ontario FIT solar PV value chain in this case study presented three different levels of profits by project size, type of installation, market segment, and location. The level of the average remuneration offered by OPA have been over-generous, especially related to ground-mounted solar PV projects. Consequently, these high solar PV rates have represented an increase on electricity prices for Ontario's electricity consumers. 
Another important insight of the economic- environmental analysis of this study is that although Ontario's electricity ratepayers currently pay for extra electricity prices to develop a clean and sustainable energy alternative (whose turnkey costs will continue decreasing over the next years to be more competitive and likely reach grid parity), as a complement there is a net environmental benefit generated as a result of installing FIT solar PV systems, considering the life cycle GHG emissions avoided can represent almost 10 times the life cycle emissions produced by solar PV systems.

As a whole, the feed-in tariff as a policy instrument has supported the Ontario solar PV development successfully in terms of energy security and GHG emissions reductions, but still there are some technical (such as low PV module efficiency and intermittency), financial (limited financing options for covering the capital costs of smaller PV systems) and regulatory (the domestic content requirements not only promote a local manufacturing solar PV industry but also limit the possibility to reach grid parity because of the not very competitive PV system prices in Ontario) barriers to overcome in order to achieve a large-scale solar PV deployment in Ontario. 


\subsection{Implications}

The implications of the findings of this research are explained below:

\subsubsection{Policy implications}

As an energy policy goal, the efficiency and the cost-effectiveness of the Ontario FIT solar PV policy has failed to promote the increasing deployment of solar PV without leading to excessive windfall profits for solar developers (IRENA 2014), and lowering the burden for Ontarian consumers; the case study of this research has demonstrated that despite the FIT program having been reevaluated and re-orientated after a review in 2012. Therefore, it is necessary to set effective and cost-efficient PV incentive schemes that decrease over time at a level that satisfies both conflicting goals (avoid overpayment from ratepayers but maintaining investor security), and revising rates periodically with a constant assessment of technology costs to foster innovation and technological improvement.

Another policy implication related to the increased cost of electricity in Ontario is the application of a risk premium over the rate of return on investment (discount rate of the solar PV project). The case study of this research showed an over-payment to ground mounted and rooftop solar PV projects over their corresponding FIT rate. These over-payments can be considered as risk 
premium or additional returns to compensate solar PV investors given the inherent high risk of the solar PV technology. These risk premiums should be related to typical operational risks of solar $\mathrm{PV}$ technologies such as grid dispatch, transmission constraints, and intermittency, which are greater for large utilityscale projects than for small commercial-scale PV systems. It is important to analyze if these over-payments going beyond of the investor security criterion.

Several components and products of the Ontario's solar PV supply chain are not produced in Ontario, basically because of the dramatic increasing of PV Asian manufacturing with competitive prices. Taking into account the successful German experience, there is a necessity to revaluate policy strategies that support the PV industry in Ontario, such as implementing more investments in R\&D to improve technology efficiency and reduce retail prices, and promote education and training so institutions can export not only solar PV products but also human capital and knowledge.

The Ontario FIT solar PV policy is still a drive-the-market policy, taken into account that the LCOE of solar PV technology have not yet reached grid parity. However, it is necessary that the policy framework evolve from a full policy adoption stage towards promoting self-sustained RE markets, with the progressive phase-out of economic incentives, but maintaining grid access guarantees and sustained R\&D support. It should be possible with an effective 
and long-term policy to allow for optimal technology progress, the achievement of cost competitiveness and grid parity.

\subsubsection{Social implications}

Generally, the social implications of the FIT solar PV program in Ontario should be oriented towards two main objectives: creation of green jobs and community participation, both of which have not been successfully reached. In addition, the increasing electricity costs in the Ontario electricity supply system due in part to the development of solar PV technology might result in a negative social effect as a consequence of the higher burden on ratepayers.

\subsubsection{Broader implications}

An important lesson from Ontario's FIT solar PV policy implementation that other jurisdictions/regions/countries with solar PV energy potential might need to know is related to policy design and periodical revisions. At the beginning of Ontario's FIT solar PV program implementation (FIT 1.0 version) it presented design issues, the high solar PV rates, even for large project sizes, allowed the opportunity to hold larger projects contracts (usually ground-mounted PV installations) and the possibility of market failure due to market concentration. After the FIT policy review in 2012, the FIT solar PV rates were revised

downward and the FIT solar PV projects sizes were delimited to $500 \mathrm{~kW}$ to avoid high market concentration from a few project developers that might lead to 
oligopolistic market behaviour. The large solar PV projects with a capacity more than $500 \mathrm{~kW}$ had to participate in a bidding procurement process.

\subsection{Future research}

Future work should be performed in the field of cost competitiveness analysis of solar PV technology. An international LCOE comparison with the LCOE of Ontario's solar PV technology should be conducted to determine how cost competitive is Ontario's solar PV technology in comparison to other regions? And how long will Ontario solar PV technology take to achieve grid parity in comparison to other technologies and regions?.

Further research should be pursued related to prioritizing the relative importance of the set of sustainability criteria to evaluate effectiveness and sustainability of FIT programs using the Analytical Hierarchy Process (AHP), a multi-criteria decision making (MCDM) tool, which translates the qualitative and subjective information to quantitative results. 


\section{APPENDICES}

\section{APPENDIX 1: Transmission Availability Map}

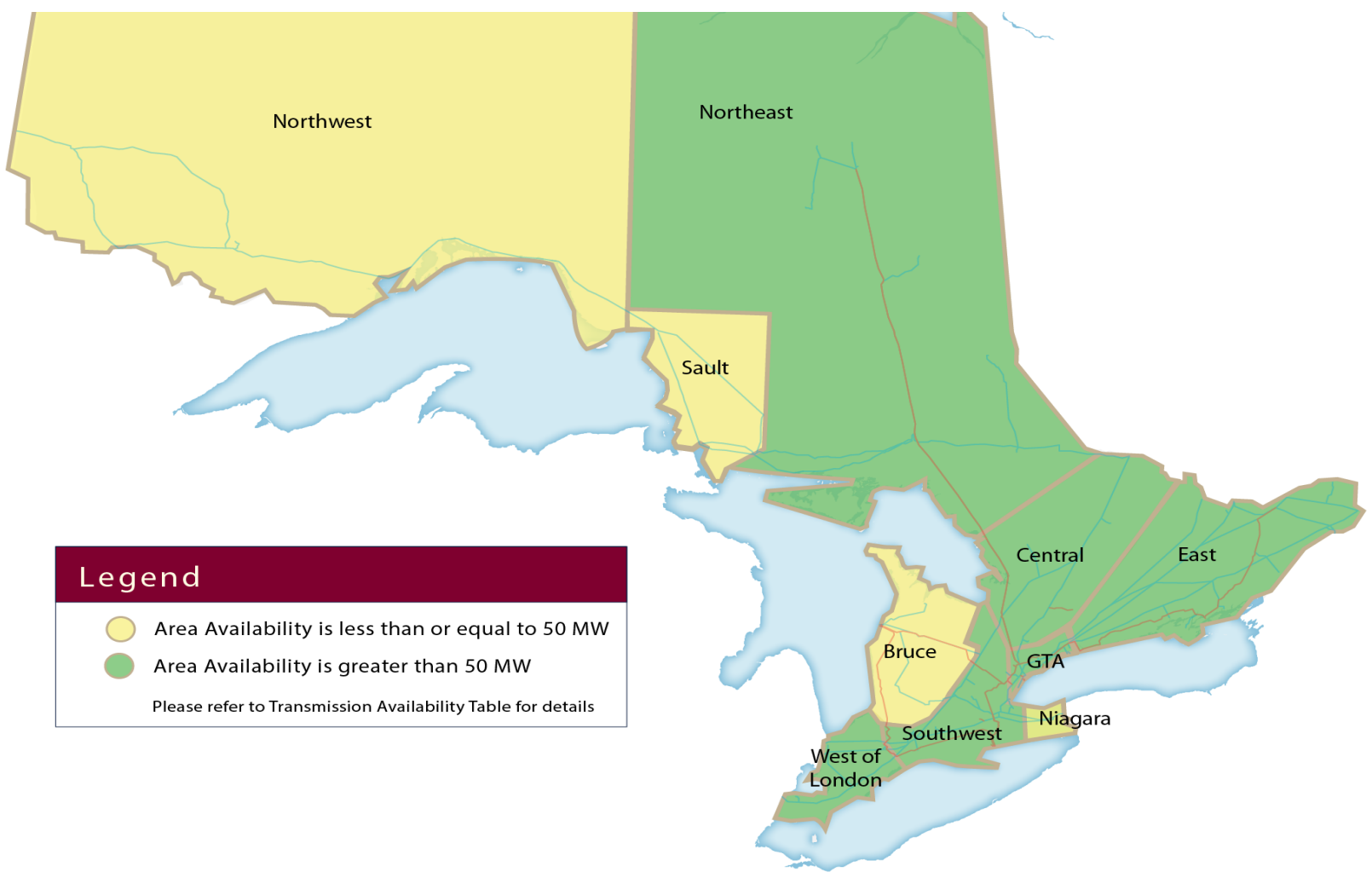

Source: OPA 2013c 


\section{APPENDIX 2: Solar PV Potential and Insolation}

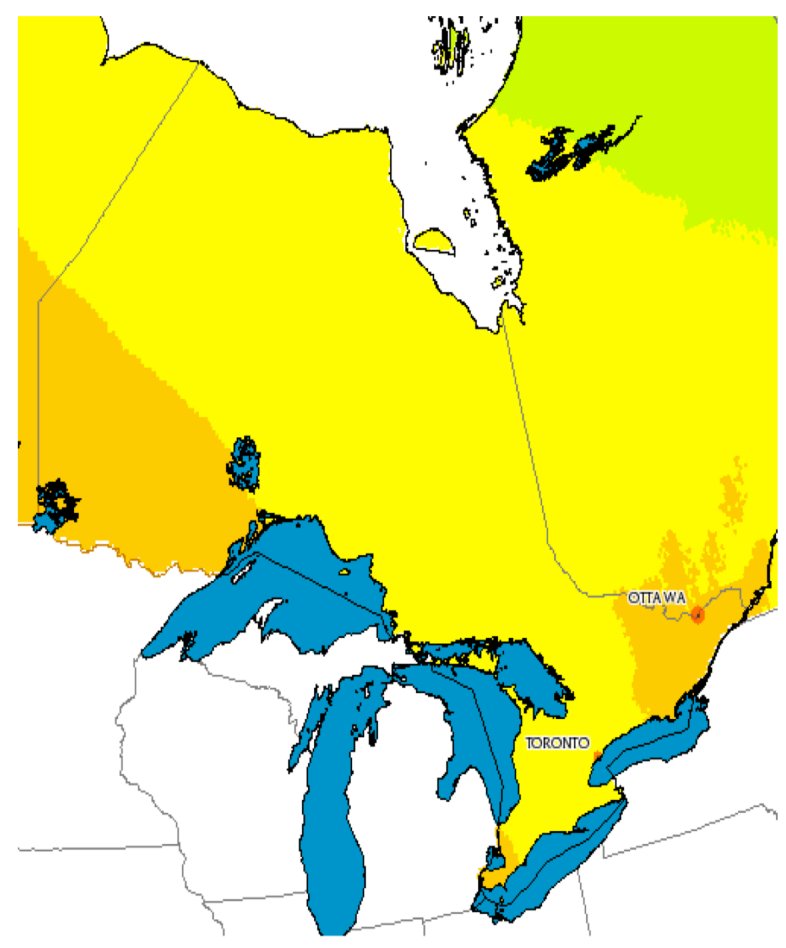

\section{Legend}

Photovoltaic potential (kWh/kW) South-facing, tilt=latitude Annual $0.500 \mathrm{kWh} / \mathrm{kW}$

$500-600$

$600-700$

$700-800$

$800-900$

$900-1000$

$1000-1100$

$1100-1200$

$1200-1300$

$1300-1400$

$1400+$

$0 \quad 190 \quad 380 \quad 570 \mathrm{~km}$

Source: NRCan ndb 
APPENDIX 3: LCOE Calculation (Scenario 1)

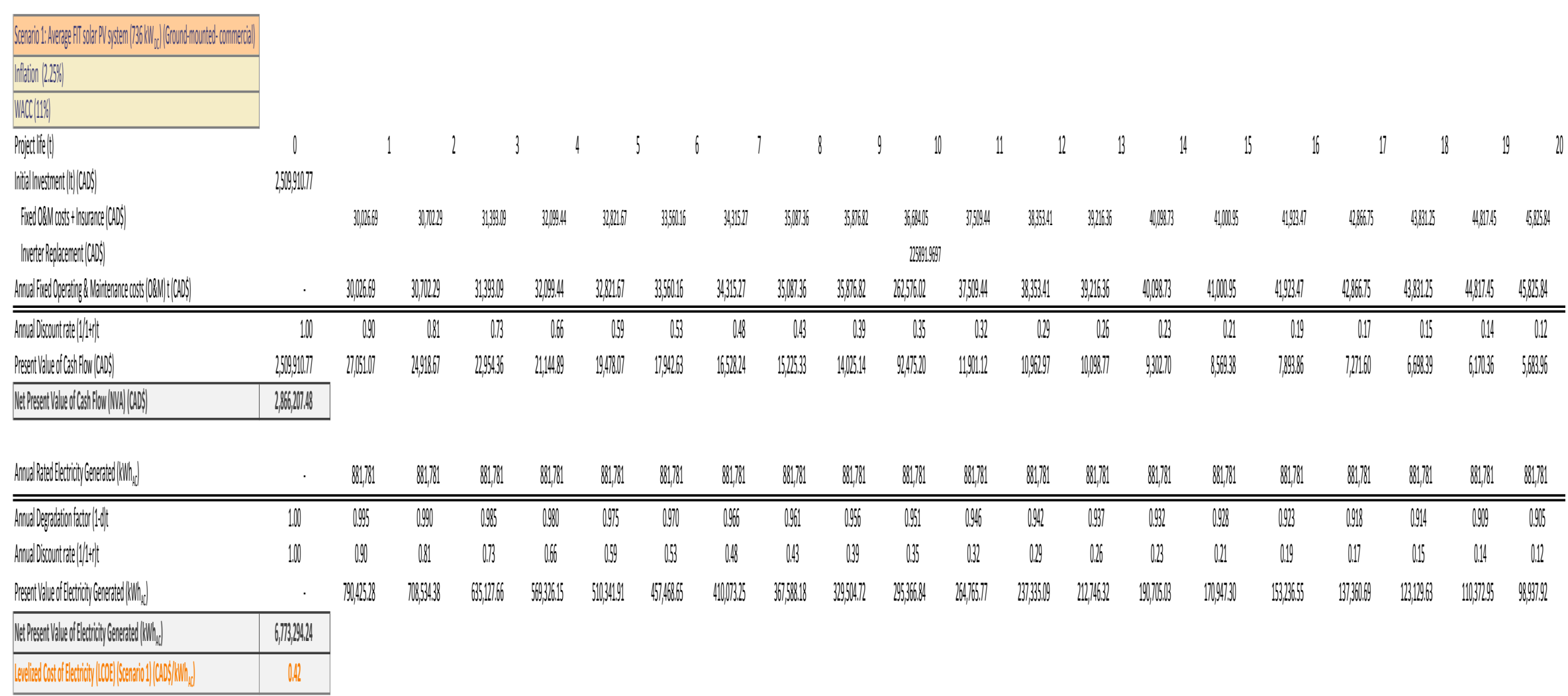


APPENDIX 4: LCOE Calculation (Scenario 2)

\begin{tabular}{|c|c|c|c|c|c|c|c|c|c|c|c|c|c|c|c|c|c|c|c|c|c|c|}
\hline \multicolumn{23}{|l|}{ 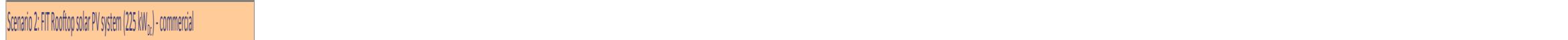 } \\
\hline \multicolumn{23}{|l|}{ Intation $\mid 2.250}$. \\
\hline \multicolumn{23}{|l|}{ Whe(CIIN) } \\
\hline Proettlet|| & 0 & $!$ & ! & & 3 & 4 & j & int & & & 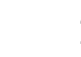 & & 11 & 11 & $B$ & & 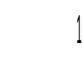 & 16 & $!$ & 18 & & 19 \\
\hline 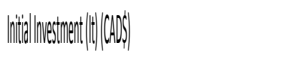 & 8556584 & & & & & & & & & & & & & & & & & & & & & \\
\hline 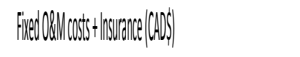 & & 9900.1. & 1024:4P & 1046 & 10,0962 & 199992 & 11,10606 & 1146689 & $11,631.1$ & 1196588 & 122455 & 14979 & & 11,7053 & 1307, 7,6 & B3, & 1360120 & 139481.12 & $1,461.196$ & 1459828 & 199068 & 152646 \\
\hline 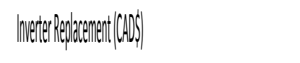 & & & & & & & & & & & 751525 & & & & & & & & & & & \\
\hline 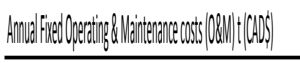 & . & gog901. & 10,4hin & 10466. & 100996 & 1999992 & 11,16506 & 11,46207 & $11,637.2$ & 1193538 & 81301.2.1.2. & $14,999$. & & 1170355 & BN, $7,1,6$ & BNAWDLW & BS64.20 & 139481.2. & 146015 & 1,402808 & 1490.66 & 15264640 \\
\hline 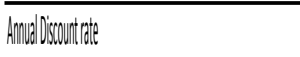 & 100 & 198 & 18. & $0, B$ & 066 & 059 & 0.33 & 0.8 & D.S & 0.99 & 0.55 & $Q_{3}$ & & 0.9 & 0.6 & D.1. & DII & 0.9 & 0.17 & 0.5 & 0.4 & 0.11 \\
\hline 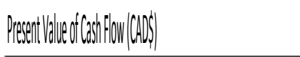 & 8556584 & gmoul. & 80905 & 1,87,1.2. & 1,1,5500 & 60044 & 5,50959 & 5.990.2. & $5 / 60549$ & 460623 & 3)/(609. & 39995 & & $3,677,1,3$ & 335999 & 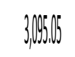 & 1851007 & 266632 & $2,490.9$ & 1212888 & 20.029.9. & 1.99128 \\
\hline 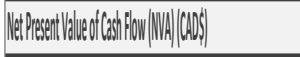 & 93599994 & & & & & & & & & & & & & & & & & & & & & \\
\hline 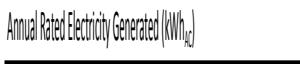 & . & 160.312 & [6.1312. & 26.312. & $20,3\} 12$ & 160.312 & 2013212 & 160.312. & 26.312 & 60.312 & 20.3212 & $60.3\}$ & & 26.313. & 161,312 & 161312 & 60,312 & 160.312 & 26.312 & 2013212 & 2613)12. & 60,312 \\
\hline 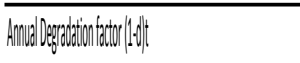 & 100 & 09.95 & 1090 & 1996 & 0980 & 0975 & 090 & 0.56 & 0980 & 0.956 & 0951. & 1946 & & 0942 & 0937 & 0.932 & 098 & 0916 & 0998 & 0.94 & 099 & 0985 \\
\hline 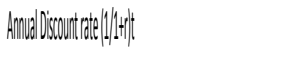 & 1.0 & 0.90 & DI! & 0.13 & 066 & 1099 & 0.33 & 048 & D. B & 039 & 0.55 & 032. & & 0.9 & 0.6 & D.B & Q.1. & 0.9 & 0.17 & 0.15 & 0.4 & Q1.12 \\
\hline 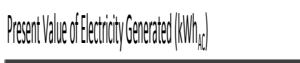 & . & $234,4,6,67$ & 190987.7 & 10821421.2 & 10871351. & 15.513.14.4 & 1.5573780. & 11251.17 .87 & 108937.15 & $97 / 50187$ & 87,33:80 & 18460.1. & & 1035500 & 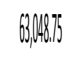 & 56,5668 & 5160134 & 45,41265 & 40,013 & 36,9016 & $32,10,7,4$ & DOSOCPS \\
\hline 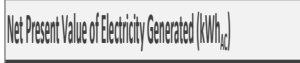 & 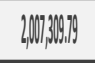 & & & & & & & & & & & & & & & & & & & & & \\
\hline 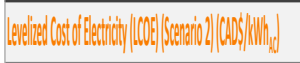 & 14 & & & & & & & & & & & & & & & & & & & & & \\
\hline
\end{tabular}


APPENDIX 5: LCOE Calculation (Scenario 3)

\begin{tabular}{|c|c|c|c|c|c|c|c|c|c|c|c|c|c|c|c|c|c|c|c|c|c|}
\hline 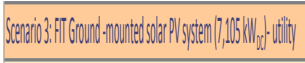 & & & & & & & & & & & & & & & & & & & & & \\
\hline Intitim $|2250|$ & & & & & & & & & & & & & & & & & & & & & \\
\hline 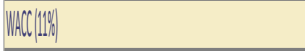 & & & & & & & & & & & & & & & & & & & & & \\
\hline Proettlet| & $l$ & & 1 & l & 3 & 4 & j & 6 & 1 & 8 & 9 & 10 & 11 & 11 & B & I4 & t. & 6 & 17 & 18 & 19 \\
\hline 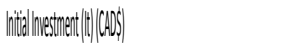 & $20892: 353.37$ & & & & & & & & & & & & & & & & & & & & \\
\hline 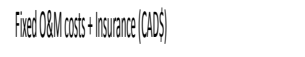 & & 2130245 & 2804069 & {$[2,3 / 538$} & 28331065 & B3509y & $287 / 25$ & $24,13.11$ & 2968285 & $25 ; 24+4,19$ & 20987879 & 2686002 & {$[2,86437$} & 290938 & 2528010 & 201,024 & 208621349 & 3094402 & 311185634 & 3888266 & 36,60685 \\
\hline 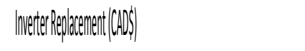 & & & & & & & & & & & 109301036 & & & & & & & & & & \\
\hline 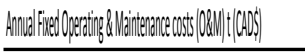 & $\cdot$ & $23,04,15$ & 2809060 & 213,45358 & 2833065 & 2335899 & 38702095 & $14,153,11$ & $24,682.5$ & $15 ; 24,19$ & $2,1,1,280.16$ & L6880002.2. & {$[2,80437$} & 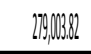 & 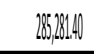 & $20,1,02,24$ & $201 / 2649$ & 34,9442 & 31186524 & 31882660 & 3600685 \\
\hline Amadicisurtitle & 1.00 & 0.8 & 108 & 0.3 & 0.66 & 0.99 & 0.53 & 0.8 & 0.3 & 039 & 0.55 & 032 & 0.9 & 0.6 & 0.13 & 01.1 & 0.9 & 0.17 & 0.15 & 0.4 & 0.11 \\
\hline 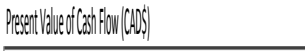 & 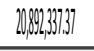 & $19,44,19$ & $171,282.5$ & 16336212 & 10,442 & 1385602 & $11 / 62542$ & 11750,13 & 1033027 & $99,80.51$ & 78,13189 & 8400.3 & $77,955,18$ & 11877,46 & $60,188.8$. & 0096062 & 50,1006 & $51,3361$. & $47,650.5$. & 43,89880 & 4,48888 \\
\hline 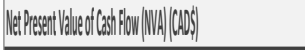 & 13,36,9045 & & & & & & & & & & & & & & & & & & & & \\
\hline 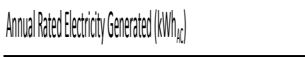 & . & 85.1133 & 8511.133 & 8,11133 & 8,11133 & 85,1133 & 88,1133 & 8511,133 & 85,1133 & 85,1133 & 85,1133 & $8,1.1332$ & 8511133 & 8511133 & 85,1133 & $85,11,33$ & 8511133 & 85,1133 & $8, j 11,333$ & $8, j 11333$ & $8,11.33$ \\
\hline 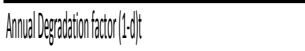 & 1.00 & 0.997 & 0993 & O990 & 0.986 & 0.980 & 0.99 & 0.976 & 0.97 & 0.900 & 0.956 & 0.052 & 0.599 & 0.955 & 0.59 & 0.949 & 0.95 & 0.94 & 0.39 & 0.936 & 0932 \\
\hline 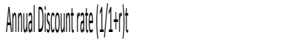 & 1.0 & 0.0 & 0.81 & 0.3 & 066 & 0.99 & 0.35 & 0.8 & ONS & 139 & 035 & 0.32 & 0.9 & 0.6 & 0.3 & 0.1 & 019 & 0.17 & 0.15 & 0.4 & 011 \\
\hline 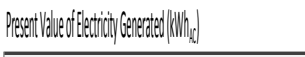 & . & 7,641.095950 & 68097171.1 & 6,1580558 & 5,58695999 & 1983282600 & $4,555,717.7$ & $4,0,1,61.28$ & $3,994,18047$ & 3,126,96647] & 2804180111 & 15993,4918 & 233669919 & $20404,316,65$ & $1,800,0107$ & $1,601,160,3$ & $1,556,18078$ & $1.30,567313$ & $1,2121,169,94$ & 10693007,7 & 940.554 \\
\hline 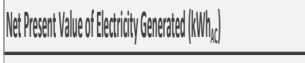 & 6010602032 & & & & & & & & & & & & & & & & & & & & \\
\hline 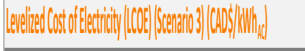 & 036 & & & & & & & & & & & & & & & & & & & & \\
\hline
\end{tabular}




\section{REFERENCES LIST}

Auditor General of Ontario. 2013. 2013 Annual Report. Chapter 4, Section 4.03: Electricity Sector: Renewable Energy Initiatives. Last access February $26^{\text {th }}$, 2013. Retrieve from

http://www.auditor.on.ca/en/reports_2013_en.htm

Bank of Canada. 2014. 10-year currency converter. Last accessed March $25^{\text {th }}, 2014$. Retrieve from

http://www.bankofcanada.ca/rates/exchange/10-year-converter/

Braeley, R.A and S.C. Myers. 1998. Corporate Finance Principles. $5^{\text {th }}$ Spanish Edition. McGraw-Hill/Interamericana de Espana S.A.U. Madrid, Spain.

Branker, K., and J.M. Pearce. 2010. Financing return for government support of large-scale thin-film solar photovoltaic manufacturing in Canada. International Journal Energy Policy, 38: 4291-4303

Branker, K., M.J.M. Pathak, and J.M. Pearce. 2011. A review of solar photovoltaic levelized cost of electricity. International Journal Renewable and Sustainable Energy Reviews, 15: 4470-4482

BP. 2013. BP Statistical Review of World Energy. Last accessed April $9^{\text {th }}$ 2014. Retrieve from http://www.bp.com/en/global/corporate/about-bp/energyeconomics/statistical-review-of-world-energy-2013.html

BMU. 2013. Renewable Energy Sources in Figures: National and International Development. Federal Ministry for the Environment, Nature Conservation and Nuclear Safety. Last accessed May $9^{\text {th }}$ 2014. Retrieve from http://www.globalbioenergy.org/uploads/media/0605_Renewable_energy_source s_in_figures_-_national_and_international_development_Germany_intl_.pdf

CanmetENERGY 2012. Sector Profile For Solar Photovoltaics in Canada. Natural Resources Canada. Last accessed May $9^{\text {th }}$ 2014. Retrieve from http://www.nrcan.gc.ca/energy/renewable-electricity/7315

CanSIA. 2014. Solar PV industry roadmap 2020. Canadian Solar Industries Association. Final draft white paper. Last accessed May 31 2014. Retrieve from http://cansia.ca/sites/default/files/20140403_cansia_white_paper_final_draft.pdf

CNE. 2013. Energy National Commission. Informacion estadistica sobre las ventas de Energia del Regimen Especial. Last accessed May $20^{\text {th }} 2014$. Retrieve from

http://www.cne.es/cne/Publicaciones?id_nodo=143\&accion=1\&soloUltimo=si\&sld Cat $=10 \&$ 
Cory, K., T. Couture, and C. Kreycik. 2009. Feed-in tariff policy: Design, implementation, and RPS policy interactions. Technical report. National Renewable Energy Laboratory. U.S. Energy Department. Last accessed July $25^{\text {th }}$, 2014. Retrieve from https://financere.nrel.gov/finance/content/feed-tariffpolicy-design-implementation-and-rps-policy-interactions

Colville, Finley. 2013. Solar PV market outlook. NDP Solarbuzz. In the $28^{\text {th }}$ EUPVSEC PV Forum. Power point presentation. Last accessed July 25 ${ }^{\text {th }}, 2014$. Retrieve from http://www.ipvea.org/fileadmin/association/img-content/pv-productionforum/PV Forum 2013/Colville Solarbuzz - EUPVSEC - Paris Sept 2013 -_IPVEA_-_Public.pdf

Das, I., K. Bhattacharya, and C. Canizares. 2012. Optimal incentive design to facilitate solar PV investments in Ontario. In Conference Proceeding IEEE Power and Energy Society General Meeting. 1-6.

Darling, S.B., F. You, T. Veselka, and A. Velosa. 2011. Assumptions and the levelized cost of energy for photovoltaics. Journal of Energy Environmental Science. 4(9): 3133-3139.

Damodaran, A. 2014. Damodaran Online. Stern School of Business, New York University. Last accessed May $25^{\text {th }}, 2014$. Retrieve from http://people.stern.nyu.edu/adamodar/

DEA. 2012. 2012 Energy Statistics. Danish Energy Agency. Last accessed May $25^{\text {th }}$ 2014. Retrieve from http://www.ens.dk/en/info/facts-figures/energy-statistics-indicators-energyefficiency/annual-energy-statistics

DEA. 2014. Danish Climate and Energy Policy. Danish Energy Agency. Last accessed May $25^{\text {th }}$ 2014. Retrieve from http://www.ens.dk/en/policy

DeLeon, P. and P. Resncik-Terry. 1999. Comparative policy analysis: Deja Vu all over again?. Journal of Comparative Policy Analysis: Research and Practice. 1:9-22.

Del Rio, P. and M. Guals. 2007. An integrated assessment of the feed-in tariff system in Spain. Int. Journal of Energy Policy. 35: 994-1012.

Del Rio Gonzalez, Pablo. 2008. Ten years of renewable electricity policies in Spain: An analysis of successive feed-in tariff reforms. Int. Journal of Energy Policy. 36: 2917- 2929.

DWIA. 2014. Industry Statistics. Danish Wind Industry Association. Last accessed May $25^{\text {th }}$ 2014. Retrieve from 
http://www.windpower.org/en/knowledge/statistics/industry_statistics.html

Evans, A., V. Strezov, and T. Evans. 2009. Assessment of sustainability indicators for renewable energy technologies. Int. Journal of Renewable and Sustainable Energy Reviews. 13: 1082-1088.

EPIA. 2014. Global market outlook for photovoltaics 2014 - 2018. European Photovoltaic Industry Association. Last accessed July 25 2014. Retrieve from http://www.epia.org/news/publications/global-market-outlook-forphotovoltaics-2014-2018/

Fraunhofer Institute for Solar Energy Systems. 2014. Recent facts about photovoltaics in Germany. Last accessed May $20^{\text {th }}$ 2014. Retrieve from http://www.ise.fraunhofer.de/en/publications/veroeffentlichungen-pdf-dateienen/studien-und-konzeptpapiere/recent-facts-about-photovoltaics-in-germany.pdf

Fthenakis, Vasilis. 2009. Sustainability of photovoltaics: The case for thinfilm solar cells. Int. Journal of Renewable and Sustainable Energy Reviews. 13: 2746-2750.

Fthenakis, V.M and H.C. Kim. 2011. Photovoltaics: life-cycle analyses. Int. Journal of Solar Energy. 85: 1609-1628.

Fthenakis, V.M, H.C. Kim, D. Hsu, and P. O'Donoughue, P. 2011. Life cycle greenhouse gas emissions of photovoltaic electricity generation: Harmonization of published estimates. In EU PVSEC Proceedings, 26th European Photovoltaic Solar Energy Conference and Exhibition. DOI: 10.4229/26thEUPVSEC2011-4AV.3.59.

Goodrich, A.C, D.M. Powell, T.L. James, M. Woodhouse, and T. Buonassisi. 2013. Assessing the drivers of regional trends in solar photovoltaic manufacturing. Journal Energy and Environmental Science. 6: 2811-2821. Electronic Supporting Materials (S1): 1-13. Last accessed July $10^{\text {th }}$. Retrieve from http://www.rsc.org/suppdata/ee/c3/c3ee40701b/c3ee40701b.pdf

Hernandez-Moro, J. and J.M. Martinez-Duart. 2013. Analytical model for solar PV and CSP electricity costs: Present LCOE values and their future evolution. Int. Journal of Renewable and Sustainable Energy Reviews. 20:119132.

Hsu, D., P. O'Donoughue, V.M. Fthenakis, G.A. Heath, H.C. Kim, P. Sawyer, J.K. Choi, and D.E. Turney, D.E. 2012. Life cycle greenhouse gas emissions of crystalline silicon photovoltaic electricity generation: Systematic review and harmonization. Journal of Industrial Ecology. 16. Issue Supplement S1: S122-S135. 
Hsu, D., P. O'Donoughue, V.M. Fthenakis, G.A. Heath, H.C. Kim, P. Sawyer, J.K. Choi, and D.E. Turney, D.E. (2012a). Life cycle greenhouse gas emissions of crystalline silicon photovoltaic electricity generation: Systematic review and harmonization. Journal of Industrial Ecology. 16. Issue Supplement S1: S122-S135. Electronic Supporting Information. Last accessed July $9^{\text {th }}, 2014$. Retrieve from http://onlinelibrary.wiley.com/doi/10.1111/j.1530-9290.2011.00439.x/full

IEA. 2010. Technology roadmap: solar photovoltaic energy. Last accessed May $20^{\text {th }} 2014$. Retrieve from http://www.iea.org/publications/freepublications/publication/pv_roadmap.pdf

IEA. 2011. Solar energy perspectives. Renewable Energy Technologies. International Energy Agency. Last accessed May 20 $0^{\text {th }}$ 2014. Retrieve from https://www.iea.org/publications/freepublications/publication/Solar_Energy_Persp ectives2011.pdf

IEA. 2013. 2013 IEA-PVPS Annual report. International Energy Agency. Photovoltaic Power Systems Programme. Last accessed May $20^{\text {th }} 2014$. Retrieve from http://www.iea-pvps.org/index.php?id=6

IESO. 2013. 2013 Annual report: Ready Set Go, capturing the new found flexibility in Ontario's power grid. Independent Electricity System Operator. Last accessed May $20^{\text {th }}$ 2014. Retrieve from http://www.ieso.ca/Documents/corp/IESO_2013AnnualReport.pdf

IESO. 2014. Price overview. Independent Electricity System Operator. Last accessed August $2^{\text {nd }}$ 2014. Retrieve from http://www.ieso.ca/Pages/Power-Data/price.aspx

Illica, M. and K. Harrison. 2007. Protecting Endangered Species in the US and Canada: The role of negative lesson drawing. Canadian Journal of Political Science. 40: 2: 367-394.

IRENA. 2014a. The socio-economic benefits of solar and wind energy report. International Renewable Energy Agency. Last accessed March 24 2014. Retrieve from http://www.irena.org/menu/index.aspx?mnu=Subcat\&PriMenulD=36\&CatID=141 \&Subcat $I \mathrm{D}=418$

IRENA. 2014b. Evaluating renewable energy policy: A review of criteria and indicators for assessment. International Renewable Energy Agency. Last accessed March $24^{\text {th }}$ 2014. Retrieve from http://www.irena.org/Publications/ReportsPaper2014New.aspx?mnu=cat\&PriMen uID=36\&Cat $\mid \mathrm{D}=141 \&$ type $=$ all 
Jacobs, D., N. Marzolf, J.B. Paredes, W. Rickerson, H. Flynn, C. BeckerBirck, and M. Solano-Peralta. 2012. Analysis of renewable energy incentives in the Latin America and Caribbean region: The feed-in tariff case. Int. Journal Energy Policy. 60: 601-610.

Knill, Christoph. 2005. Introduction: Cross-national policy convergence: concepts, approaches and explanatory factors. Journal of European Public Policy 12(5): 764-774.

Koepffer, Walter. 2008. Life Cycle Sustainability Assessment of Products. International Journal of Life Cycle Assessment. 13(2): 89-95.

Laird, F., and C. Stefes. 2009. The diverging paths of German and United States policies for renewable energy: Sources of difference. Journal of Energy Policy. 37: 2619- 2629.

Lipp, Judith. 2007. Lessons for effective renewable electricity policy from Denmark, Germany and the United Kingdom. Journal of Energy Policy. 35: 5481-5495.

Luukkonen, P, P. Bateman, J. Hiscock, Y. Poissant, D. Howard, and L. Dignard-Bai. 2013. 2012 National survey report of PV power applications in Canada. International Energy Agency. Co-operative Programme on Photovoltaic Power Systems. Last accessed May $20^{\text {th }} 2014$. Retrieve from http://www.ieapvps.org/index.php?id=93\&no_cache=1\&tx_damfrontend_pi $1 \% 5$ BshowUid\%5D= 740\&tx_damfrontend_pi $1 \% 5$ BbackPid $\% 5 \mathrm{D}=93$

Mabee, W., J. Mannion, and T. Carpenter. 2011. Comparing the feed-in tariff incentives for renewable electricity in Ontario and Germany. Int. Journal Energy Policy. 40: 480-489.

Masson, Gaetan. 2014. Overview of current market trends for PV systems. European photovoltaic industry association (EPIA). In the IEA Solar Roadmap Workshop 2014. Power Point presentation. Last accessed May $20^{\text {th }}$ 2014. Retrieve from

https://www.iea.org/media/workshops/2014/solarelectricity/NEWGaetanMassonO verviewofCurrentMarketTrendsPVSystems.pdf

Maxim, Alexandru. 2014. Sustainability assessment of electricity generation technologies using weighted multi-criteria decision analysis. Int. Journal Energy Policy. 65: 284-297.

McKenney, D, W. Pelland, Y. Poissant, R. Morris, M. Hutchinson, P. Pia Papadopol, K. Lawrence, and K. Campbell. 2008. Spatial insolation models for photovoltaic energy in Canada. Journal of Solar Energy. 82: 1049-1061. 
Mendonca, M., D. Jacobs, and B. Sovacool. 2009. Powering the Green Economy: The Feed-in tariff handbook. Earthscan. London. pp. xxvii, 91.

MINETUR. 2012. Libro de la Energia en Espana 2011. Ministry of Industry, Energy and Tourism. Spain Government. Last accessed May 20 2014. Retrieve from http://www.minetur.gob.es/energia/balances/Balances/Paginas/Balances.aspx

Moore, S., V. Durant, and W. Mabee. 2013. Determining appropriate feedin tariff rates to promote biomass-to-electricity generation in Eastern Ontario, Canada. Int. Journal Energy Policy. 63 : 607-613.

Mundo-Hernandez, J., B. de Selis Alonso, J. Hernandez-Alvarez, and B. de Selis-Carrillo. 2014. An overview of solar photovoltaic energy in Mexico and Germany. International Journal Renewable and Sustainable Energy Reviews. 31: 639-649.

Muneer, W., K. Bhattacharaya, and C. Canizares. 2011. Large-scale solar PV investments models, tools, and analysis: The Ontario case. IEEE Transactions on Power Systems. 26(4): 2547-2555.

NRCan. nda. PV municipal rankings and hotspots. Last accessed February $10^{\text {th }}$ 2014. Retrieve from http://pv.nrcan.gc.ca/?lang=e\&m=r

NRCan. ndb. Photovoltaic potential and solar resource maps of Canada. Last accessed February $10^{\text {th }}$ 2014. Retrieve from http://pv.nrcan.gc.ca

NREL. 2011. 2010 Solar Technologies Market Report. U.S. National Renewable. U.S. Department of Energy. Last accessed May $12^{\text {th }} 2014$. Retrieve from http://www.nrel.gov/docs/fy12osti/51847.pdf

NREL. 2012. Life Cycle Greenhouse Gas Emissions from Solar Photovoltaics (Fact Sheet). U.S. National Renewable. U.S. Department of Energy. Last accessed May $12^{\text {th }}$ 2014. Retrieve from http://www.nrel.gov/analysis/sustain_lcah.html

NREL. nda. System Advisor Model (SAM). U.S. National Renewable Energy Laboratory. U.S. Department of Energy. Last accessed May $12^{\text {th }} 2014$. Retrieve from https://www.nrel.gov/analysis/sam/help/htmlphp/index.html?mt_capacity_factor.htm

NREL. ndb. System Advisor Model (SAM). U.S. National Renewable Energy Laboratory. Last accessed May $12^{\text {th }}$ 2014. Retrieve from https://www.nrel.gov/analysis/sam/help/htmlphp/index.html?mt_capacity_factor.htm 
O'Donoughue, P., G.A. Heath, S.L. Dolan, and M. Vorum. 2014. Life Cycle greenhouse gas emissions of electricity generated from conventionally produced natural gas: Systematic review and harmonization. Journal of Industrial Ecology. 18(1): $125-144$.

Ontario. 2009. Ontario's Green Energy and Green Economy Act. Ministry of Energy. Last accessed February $8^{\text {th }}$ 2014. Retrieve from http://www.greenenergyact.ca.

Ontario. 2012. Ontario's Feed-in Tariff program - Two-Year review report. Ministry of Energy. Last Accessed February 26th 2014. Retrieve from http://www.energy.gov.on.ca/en/fit-and-microfit-program/2-year-fitreview/executive-summary/

OPA. 2010a. Rationale for new ground-mount FIT price category. Ontario Power Authority. Toronto, Canada. Last accessed May $25^{\text {th }}, 2014$. Retrieve from http://powerauthority.on.ca/news/rationale-new-ground-mount-fit-price-category

OPA. 2010b. Details of proposed rate calculation. Ontario Power Authority. Toronto, Canada. Last accessed May $25^{\text {th }}, 2014$. Retrieve from http://powerauthority.on.ca/news/details-proposed-rate-calculation

OPA. 2012. Bi weekly FIT and microFIT Report, August 2012. Ontario Power Authority. Toronto, Canada. Last accessed May $25^{\text {th }}$, 2014. Retrieve from http://fit.powerauthority.on.ca/program-updates/past-updates/bi-weekly-fit-andmicrofit-program-reports-version-1

OPA. 2013a. Ontario's Long-Term Energy Plan. Ontario Power Authority. Toronto, Canada. Last accessed March 25 ${ }^{\text {th }}$, 2014. Retrieve from www.powerauthority.on.ca

OPA. 2013b. 2013- Q4 A progress report on contracted electricity supply. Ontario Power Authority. Toronto, Canada. Last accessed May $29^{\text {th }}, 2014$. Retrieve from http://powerauthority.on.ca/sites/default/files/documents/OPA\%20$\% 20$ Q4\%202013\%20Electricity\%20Supply\%20Report $\% 20$ -

\%20final\%20for\%20posting\%20May\%209.pdf

OPA. 2013c. FIT 3 Transmission Availability Map. Ontario Power Authority. Toronto, Canada. Last accessed May $17^{\text {th }}$, 2014. Retrieve from http://fit.powerauthority.on.ca/sites/default/files/version3/FIT\%203\%20Area\%20M ap\%20-\%200ctober\%203\%202013.png

OPA. 2013d. Price Schedules. Program Resources. Ontario Power Authority. Toronto, Canada. Last accessed May $17^{\text {th }}, 2014$. Retrieve from 
http://fit.powerauthority.on.ca/program-resources/program-archives/priceschedules

OPA. 2014a. Feed price schedule, updated January $1^{\text {st }}, 2014$. Program Pricing. Ontario Power Authority. Toronto, Canada. Last accessed March $25^{\text {th }}$, 2014. Retrieve from http://fit.powerauthority.on.ca/fit-program/fit-programpricing/fit-price-schedule

OPA. 2014b. FIT 3.0 Applications Summary. Program Updates. Ontario Power Authority. Toronto, Canada. Last accessed May $10^{\text {th }}, 2014$. Retrieve from http://fit.powerauthority.on.ca/program-updates/newsroom/newsroom-2014

OPA. 2014c. FIT contract offers. Program Updates. Ontario Power Authority. Toronto, Canada. Last accessed May $10^{\text {th }}, 2014$. Retrieve from http://fit.powerauthority.on.ca/program-updates/contract-offers

Pacific Carbon Trust. 2014. B.C Carbon Neutral Government. Last accessed August $10^{\text {th }}, 2014$. Retrieve from http://www.pacificcarbontrust.com/what-we-do/carbon-neutral-government/

Palmer, K. and D. Burtrow. 2005. Cost-effectiveness of renewable electricity policies. International Journal Energy Economics. 6: 873-894.

PANER. 2010. Plan de Acción Nacional de Energías Renovables 20112020. Ministry of Industry, Energy and Tourism. Spain Government. Last accessed May $20^{\text {th }}$ 2014. Retrieve from

http://www.minetur.gob.es/energia/desarrollo/EnergiaRenovable/Paginas/Paner. aspx

Powell, D, M.T Winkler, A. Goodrich, and T. Buonassisi. 2013. Modeling the Cost and Minimum Sustainable Price of Crystalline Silicon Photovoltaic Manufacturing in the United States. Electronic supporting information. IEE Journal of Photovoltaics. 3(2) : 662-668. Last accessed May14 ${ }^{\text {th }}$ 2104. Retrieve from http://pv.mit.edu/tma/

Reichelstein, S and M. Yorston. 2013. The prospects for cost competitive solar PV power. Int. Journal of Energy Policy, 55:117-127.

REN21. 2013. Renewables 2013 Global Status Report. Renewable Energy Policy Network for the 21st Century. Last accessed April 14 2104. Retrieve from http://www.ren21.net/portals/0/documents/resources/gsr/2013/gsr2013_lowres.p df

RESLegal. 2014. Germany Feed-in Tariff Program. Legal sources on renewable energy. Last accessed March $25^{\text {th }}, 2014$. Retrieve from 
http://176.9.160.135/search-by-country/germany/single/s/rese/t/promotion/aid/feed-in-tariff-eeg-feed-in-tariff/lastp/135/

Rigter, J. and G. Vidican. 2010. Cost and optimal feed-in tariff for small scale photovoltaic systems in China. International Journal Energy Policy. 38: 6989-7000.

Rose, Richard (2005). Learning from comparative policy analysis. London and New York. Routledge. pp, 1-26.

Sherwani, A.F, J.A. Usamni, and Varun. 2014. Life cycle assessment of solar PV based electricity generation systems: A review. International Journal Renewable and Sustainable Energy Reviews. 14: 540-544.

Solangi, K.H., M.R. Islam, R. Saidur, N.A. Rahim, and H. Fayaz. 2011. A review on global solar energy policy. International Journal Renewable and Sustainable Energy Reviews. 15: 2149-2163.

Solarbuzz. 2014. Solar Market Research and Analysis. Last accessed May $25^{\text {th }}, 2014$. Retrieve from http://www.solarbuzz.com

Stokes, Leah. 2013. The politics of renewable energy policies: The case of feed-in tariffs in Ontario, Canada. Int. Journal of Energy Policy. $56:$ 490-500.

Timilsina, G., L. Kurdgelashvili, and P.A. Narbel. 2012. Solar energy: Markets, economics and policies. Journal of Renewable and Sustainable Energy Reviews. 16 : 449- 465.

Valdivia, S., C.M.L. Ugaya, J. Hildenbrand, M. Traverso, B. Mazijn, and G. Sonnemann. 2013. A UNEP/SETAC approach towards a life cycle sustainability assessment-our contribution to Rio+20. International Journal of Life Cycle Assessment. 18:1673-1685.

Vergara, W., C. Alatorre, and L. Alves. 2013. Rethinking our energy future: A white paper on renewable energy in the 3GFLAC regional forum. InterAmerican Development Bank. Climate Change and Sustainability Division. Energy Division. Discussion paper: No. IDB-DP-292. Last accessed May $20^{\text {th }}$ 2014. Retrieve from http://publications.iadb.org/handle/11319/5744

Yatchew, A. and A. Baziliauskas. 2011. Ontario feed-in tariff programs. Journal of Energy Policy. 39: 3885-3893.

Yue, D, F. You, and S. Darling. 2014. Domestic and overseas manufacturing scenarios of silicon-based photovoltaics: Life cycle energy and environmental comparative analysis. Journal of Solar Energy. 105: 669-678. 
Walsh, Philip R. 2011. Creating a "values" chain for sustainable development in developing nations: where Maslow meets Porter. International Journal Environment, Development and Sustainability. 13 (4): 789-805.

Wiginton, L.K., H.T. Nguyen, and J.M. Pearce. 2010. Quantifying rooftop solar photovoltaic potential for regional renewable energy policy. International Journal Computers, Environment and Urban Systems. 34: 345-357.

Zamagni, Alessandra. 2012. Life cycle sustainability assessment. International Journal Life Cycle Assess. 17: 373-376.

Zweibel, K. 2010. Should solar photovoltaics be deployed sooner because of long operating life at low, predictable cost?. Int. Journal of Energy Policy. 38 : 7519-7530.

Zhoa, Y., K.K. Tang, and L. Wang. 2013. Do renewable electricity policies promote renewable electricity generation? Evidence from panel data. International Journal Energy Policy. 62: 887-897. 